Portland State University

PDXScholar

\title{
Job Attribute Preferences of the Workforce in Polish High Technology Enterprises
}

Florian Michael Sisavic

Portland State University

Follow this and additional works at: https://pdxscholar.library.pdx.edu/open_access_etds

Part of the International Business Commons, and the Management Information Systems Commons Let us know how access to this document benefits you.

\section{Recommended Citation}

Sisavic, Florian Michael, "Job Attribute Preferences of the Workforce in Polish High Technology Enterprises" (1993). Dissertations and Theses. Paper 1185.

https://doi.org/10.15760/etd.1184

This Dissertation is brought to you for free and open access. It has been accepted for inclusion in Dissertations and Theses by an authorized administrator of PDXScholar. Please contact us if we can make this document more accessible: pdxscholar@pdx.edu. 
JOB ATTRIBUTE PREFERENCES OF THE WORKFORCE IN POLISH HIGH TECHNOLOGY ENTERPRISES

\author{
by \\ FLORIAN MICHAEL SISAVIC
}

A dissertation submitted in partial fulfillment of the requirements for the degree of

\author{
DOCTOR OF PHILOSOPHY \\ in \\ SYSTEM SCIENCE: \\ BUSINESS ADMINISTRATION
}

Portland State University

(C) 1993 


\section{TO THE OFFICE OF GRADUATE STUDIES:}

The members of the Committee approve the dissertation of Florian Michael Sisavic presented March 24, 1993.

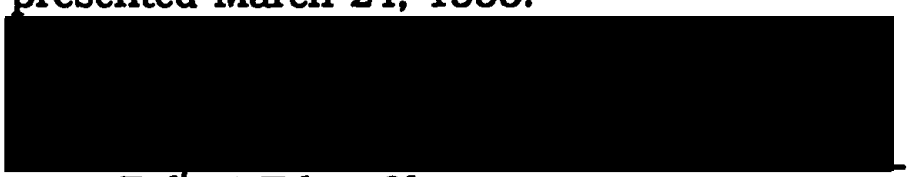

Robert Eder, Chair

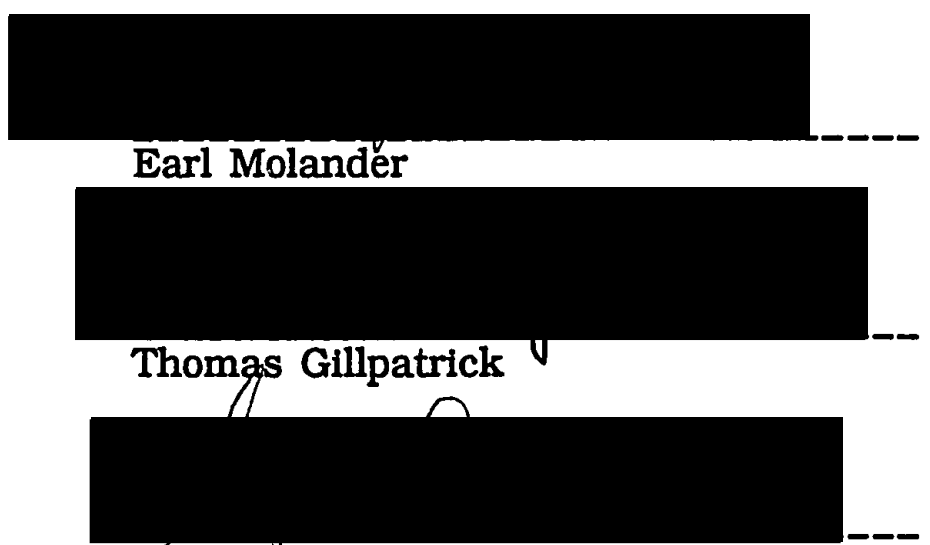

George Lendaris

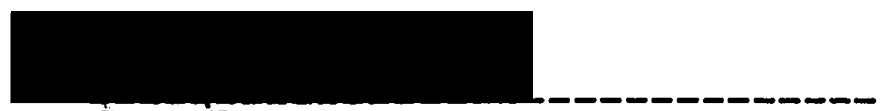

Grant Farr

APPROVED:

Beatrice Oshika, Director of System Science Ph.D. Program

Roy W. Koch, Vice Provost for Graduate Studies and Research 
AN ABSTRACT OF THE DISSERTATION OF Florian Michael Sisavic for the Doctor of Philosophy in Systems Science: Business Administration presented March 24, 1993.

Title: Job Attribute Preferences of the Workforce in Polish High Technology Enterprises.

APPROVED BY THE MEMBERS OF THES DISSERTATION COMIMITTEE:

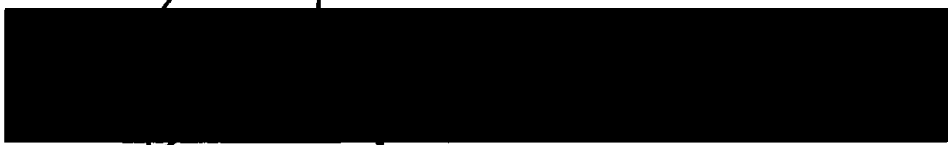

Rōbert Eder, Chair

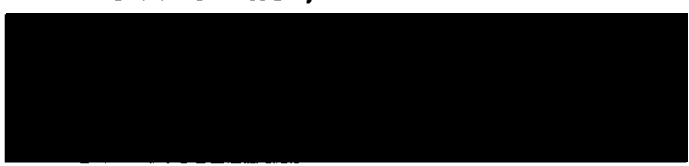

Earl Molander

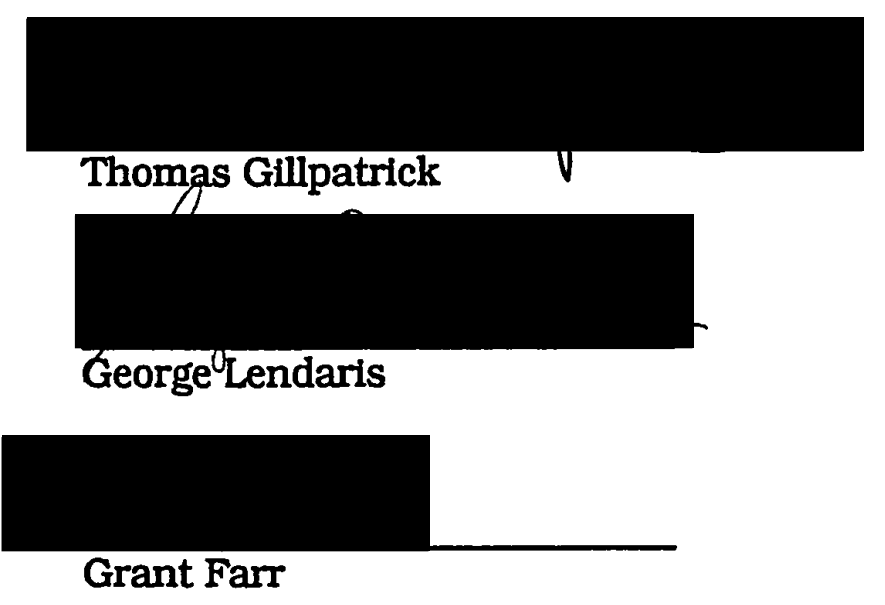

A key precept in work place motivation theory is that management knows what job attributes are valued by the employee. Management can benefit by asking employees what they want from their work experience 
(i.e., job attribute preferences), rather than assume they know. This is particularly important to Polish high technology companies that are in transition to a free-market economy and to Polish workers who must be appropriately motivated to compete globally.

This study attempts to better understand the job attribute preferences of Polish managers and workers, the potential gaps between Polish managers' perception of their workers' preferences (system), and how these preferences are affected by the worker's personal economic situation (sub system) and by business organization type (supra system). Managers and workers from five Polish high technology enterprises were surveyed on-site regarding their job attribute preferences. The results were compared to a similar survey done with six American high technology firms (Eder 1988).

Consistent with Maslow's prepotentcy theory, workers who tended to be optimistic about their personal economic situation rated all five extrinsic job attributes higher and four of the five intrinsics lower than those workers who tended to be pessimistic. Polish workers at firms that operated under central planning had only a few differences in their job attribute preferences indicating a strong supra-system or organizational effect on individuals in the firm.

Contrary to what was expected, the Polish managers and workers rated a number of intrinsic attributes higher than their American counterparts suggesting a pent up need for intrinsic-type motivational policies.

Polish managers appeared to be closer and more in touch with their workers than their American counterparts. American managers clearly underestimated the importance of intrinsic job attributes and 
overestimated the importance of the extririsics, while Polish managers accurately predicted most of the workers' job attribute preferences.

The results also raised questions regarding the stability of the job attributes and the concept of clusters of extrinsic and intrinsic groups of job attributes. 
TABLE OF CONTENTS

PAGE

LIST OF TABLES $\ldots \ldots \ldots \ldots \ldots \ldots \ldots \ldots \ldots \ldots \ldots$ vi

LIST OF FIGURES $\ldots \ldots \ldots \ldots \ldots \ldots \ldots \ldots \ldots \ldots \ldots \ldots \ldots$

CHAPTER

I INTRODUCTION. ...................... 1

Purpose of Study $\ldots \ldots \ldots \ldots \ldots \ldots \ldots \ldots \ldots$

Poland in Transition . . . . . . . . . . . . . . . . 4

Research Question ..................6

Importance of the Research Question .......... 11

II REVIEW OF THE LITERATURE . . . . . . . . . . 15

Generalized Motivation Process Model Including the Role of Data on Job Attribute Preferences . . . . . . . . 15

A Systems Model of the Variables Affecting the Motivational Process in Organizational Settings . . . . 19

Polish Management Practices and Behavior -- A Review ........................23

Polish Worker Motivation $\ldots \ldots \ldots \ldots \ldots \ldots \ldots$

Polish Manager Motivation . . . . . . . . . . . . . . 34

Mismatch of Job Attribute Preferences . . . . . . . . . . 37

The Organizational (Supra System) Influence on the

Research Question (System) . . . . . . . . . . . . 54

Summary of the Hypotheses . . . . . . . . . . . . . . . . . 59 
III RESEARCH DESIGN . . . . . . . . . . . . . 60

Sample.........................6 60

Research Instruments $\ldots \ldots \ldots \ldots \ldots \ldots \ldots \ldots, 61$

Data Collection Procedures ...............66 63

Data Analysis Plan .................... 65

Limitations . . . . . . . . . . . . . . . . . . . . 68

IV ANALYSIS OF RESEARCH FINDINGS $\ldots \ldots \ldots \ldots \ldots 71$

Characteristics of the Sample ............. 72

Results: Poland versus America (hypotheses 1 and 3) . . 83

Results: Polish managers versus workers (hypotheses 4 and 5) ............................. 92

Results: Polish pessimists versus optimists

(hypothesis 2) ......................... 100

Results: Polish firm differences (hypothesis 6) . . . . . 107

Results: A summary (All hypotheses) . . . . . . . . . . 111

V DISCUSSION ...................... 126

Limitations . . . . . . . . . . . . . . . . . 126

Key Findings $\ldots \ldots \ldots \ldots \ldots \ldots \ldots \ldots \ldots \ldots, 127$

Implications for Job Attribute Preference Research . . . . 135

Implications for Management Practices . . . . . . . . 138

Conclusions .......................... 139

REFERENCES ............................ 141

APPENDICES ............................ 146

A STATE DIRECTIVE TOPICS ............. 146 
B SUMMARY OF RESULTS FROM STUDIES ON THE GAPS OF JOB ATTRIBUTE PREFERENCES . . . 148

C ENGLISH VERSION OF WORKER'S QUESTIONNAIRE. . . . . . . . . . . . 150

D ENGLISH VERSION OF MANAGER'S QUESTIONNAIRE. . . . . . . . . . . . 155

E ORGANIZATIONAL VARIABLES QUESTIONNAIRE . . . 161

F MOTIVATIONAL PRACTICES AND SYSTEMS GUESTIONINAIRE. ................ 163

G POLISH VERSION OF WORKERS AND MANAGER'S GUESTIONNAIRE. . . . . . . . . . . . 167

H FIRM DEMOGRAPHICS .............. 177

I FREQUENCY DISTRIBUTION OF THE PERSONAL ECONOMIC SITUATION (PES) . . . . . . . 179 


\section{LIST OF TABLES}

TABLE

I Variables affecting the motivational process in organizational settings 21

II What Poles would do with "lots of money" . . . . . . 29

III A match of Maslow's hierarchy with job attributes . 30

IV Job attributes and what U.S. workers "want more of . . . . . . . . . . . . . . . . 39

$\mathrm{V}$ Job preference ratings and rankings of U.S. workers and managers in 1975 .

VI U.S. managers', workers', and managers' perception of workers' job attribute preferences . . . . . . . 43

VII U.S. managers' ranking of workers and themselves . . . . . . . . . . . . . . . . . . . . 44

VIII Ranking of U.S. Employee job attribute preferences by the employees themselves and their supervisors

IX Job attribute preferences for employees in South Africa ...................48

$\mathrm{X} \quad$ Production problems as perceived by workers and managers in Poland . . . . ......... 51

XI Research sample: respondents by firm . . . . . . 73

XII Research sample: respondents by job type and gender ....................... 74

XIII Correlation matrix: intrinsic job attributes and major demographic variables for Polish workers

XIV Correlation matrix: extrinsic job attributes and 
major demographic variables for Polish

workers ..................... 80

XV Correlation matrix: intrinsic job attributes and major demographic variables for Polish

managers.

XVI Correlation matrix: extrinsic job attributes and Major demographic variables for Polish managers.

XVII Hypothesis 1a - Extrinsic job attributes for workers: Mann-Whitney and T-tests results . . . 84

XVIII Hypothesis lb - Intrinsic job attributes for workers: Mann-Whitney and T-tests results . . . 86

XIX Hypothesis 3a - Extrinsic job attributes for managers: Mann-Whitney and T-tests results . . . 89

XX Hypothesis $3 \mathrm{~b}$ - Intrinsic job attributes for managers: Mann-Whitney and T-tests results . . .91

XXI Hypothesis 4 - Managers' perception of workers and workers' intrinsic job attribute preferences: Mann-Whitney and T-Tests results ........................ 94

XXII Hypothesis 4 - Managers' perception of workers and workers' intrinsic job attribute preferences: Likert rating results . . . . . . . . . 96

XXIII Hypothesis 5 - Managers' perception of workers and workers' extrinsic job attribute preferences: Mann-Whitney and T-Tests

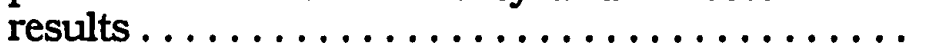

XXIV Hypothesis 5 - Managers' perception of workers and workers' extrinsic job attribute preferences: Likert rating results . . . . . . . . . . .

XXV Hypothesis 2a - Extrinsic attributes for pessimists and optimists: Mann-Whitney and T-tests results ...................... 101

XXVI Hypothesis 2a - Extrinsic attributes for pessimists and optimists: Likert rating results . . . . . . . 103 
XXVII Hypothesis $2 \mathrm{~b}$ - Intrinsic attributes for pessimists and optimists: Mann-Whitney and T-tests results . . . . . . . . . . . . . . . . . . . . . . . . . . 104

XXVIII Hypothesis $2 b$ - Intrinsic attributes for pessimists and optimists: Likert rating results . . . . . . . 106

XXIX Hypothesis 6a - Extrinsic attributes for firms: Likert rating results . . . . . . . . . . . 108

XXX Hypothesis $6 \mathrm{~b}$ - Intrinsic attributes for firms: Likert rating results . . . . . . . . . . . 110

XXXI Summary of the results for the intrinsic job attribute clusters for all hypotheses ........ 113

XXXII Summary of the results for the extrinsic job attribute clusters for all hypotheses . . . . . . . . 114

XXXIII Summary of the results for the Results job attribute for all hypotheses ............ 116

XXXIV Summary of the results for the Interesting job attribute for all hypotheses . . . . . . . . 117

XXXV Summary of the results for the Growing job attribute for all hypotheses ............ 118

XXXVI Summary of the results for the Develop job attribute for all hypotheses . . . . . . . . . . . 119

XXXVII Summary of the results for the Say job attribute for all hypotheses ............. 120

XXXVIII Summary of results for the Security job attribute for all hypotheses ............. 121

XXXIX Summary of results for the Good pay job attribute for all hypotheses . . . . . . . . . 122

XXXX Summary of results for the Recognition job attribute for all hypotheses ........... 123

XXXXI Summary of results for the Benefits job attribute for all hypotheses . . . . . . . . . . 124

XXXXII Summary of results for Friends job attribute for all hypotheses ............. 125 


\section{LIST OF FIGURES}

1. A generalized model of the basic motivation process. ...................... 16

2. A generalized model for the customer purchase process.

3. A generalized model of the basic customer purchase process with marketing management influence .............. 18

4. A generalized model of the basic motivation process modified to include the role of job attribute preference research. ................20

5. Frequency distribution for tenure (years). . . . . . . 75

6. Frequency distribution for age (years). . . . . . . . 75

7. Frequency distribution of personal economic situation (PES). . . . . . . . . . . . 76

8. Profile of extrinsic job attributes for Polish and American workers . . . . . . . . . . . . . 85

9. Profile of intrinsic job attributes for Polish and American workers ............... 87

10. Profile of extrinsic job attributes for polish and American managers ................ 90

11. Profile of intrinsic job attributes for Polish and American managers . . . . . . . . . . . . . . 92

12. Profile of Polish workers' intrinsic job attributes preferences by workers and managers. . . . . . 95

13. Profile of Polish workers' extrinsic job attribute preferences by workers and managers. . . . . . 98 
14. Profile of extrinsic job attributes for pessimists and optimists. . . . . . . . . . . . . . . 102

15. Profile of intrinsic job attributes for pessimists and optimists..................... 105

16. Profile of extrinsic job attributes for five Polish high technology firms . . . . . . . . . . 109

17. Profile of intrinsic job attributes for five Polish high technology firms . .......... 111 


\section{CHAPTER I}

\section{INTRODUCTION}

The goal of this doctoral research is to present a general framework for the study of job attribute preferences for workers and managers in the Polish enterprise.

Chapter I describes the purpose of the dissertation and background information on the Polish economic situation, which is the setting for this empirical study. Fundamental research questions are posed followed by a discussion of the importance of this study for both U. S. business investments in Poland and Polish business practices.

\section{PURPOSE OF STUDY}

The subject of this dissertation could be considered one of the starting points for reform of management practices in enterprises in former centrally planned economies. Management has been defined as getting things done through people (Schoderbek, Cosier, and Aplin 1991: 21). To be effective at this, managers in both Western and centrally planned economies need to understand and apply motivation theory. The proper application of motivational theories fosters more productive workers and managers, key factors in the successful reform of Poland's economy toward a free-market system.

A better understanding of what motivates workers and managers is a prerequisite to developing preferred management policies and 
philosophies that will activate free-market-style work motivation. Managers in centrally planned economies, like Poland, might benefit from adapting motivational policies and practices that are more typically found in Western free-market economies. Although there is no comprehensive "master" theory about motivation and work, considerable research has been done and many models developed which contribute to the understanding of this complex subject (Steers and Porter 1991). Regardless of the motivational theory, a key assumption is that the person doing the motivation knows what attributes or features of the work situation are motivating to the individual. Rather than assuming management knows what workers want, management can benefit from asking the affected employees what they want from their work experience.

The process of asking workers what they want from their job experience and then developing motivational policies based on these results can be considered similar to the marketing concept of researching customer needs in order to modify the product to satisfy the customer with product benefits (Kotler 1992, and Peter and Olson 1990). This concept, which could be called "internal marketing," will be discussed in detail later in this dissertation.

This dissertation focuses on one of the first steps needed to reform managerial thinking and motivational practices in Poland. A study was designed to better understand (1) the job attribute preferences of managers and workers in Polish companies, (2) the gaps or mismatches between Polish managers' perceptions of their workers' job attribute preferences and Polish workers' statement of 
their own job attribute preferences, and (3) selected demographic and organizational effects on these preferences. Job attributes are those values that are important and are related to the work experience (Kahn 1972).

There appears to be an absence of systematic, formal, empirical research to describe what workers in centrally planned economies want from their job experiences and how managers in enterprises perceive these job attribute preferences. What is presented is often anecdotal experiences by Western visitors. This dissertation systematically studies job attribute preferences and the extent to which Polish managers' correctly perceive their workers' job attribute preferences. The study's results can be used by both Polish and Western business partners in the design of effective work motivation systems and policies within a transitional economy.

Poland was chosen for this research because it has been one of the countries in the forefront of national economic transition and the first previously communist country to aggressively move towards a free-market economy in all sectors and with the least restrictions. Furthermore, Poland's economic and political situation have been relatively stable since the start of its transition in late 1989. Russia and most of the former Soviet republics are still trying to choose the direction and speed of reforms; Czechoslovakia is very busy with its political reorganization into two independent states; Romania and Bulgaria are much poorer countries, with somewhat less stable governments: Yugoslavia (or Croatia, etc.) is in the middle of a serious civil war; East Germany is a special case with its unification with West 
Germany; and Hungary has a long history of reform and in many ways is too far along in its transition to a free-market economy to be a suitable example of pure economic transitions.

In summary, the pivotal questions of this research revolve around what workers and managers want in their job experience, what managers think workers want, and the mismatches or gaps between the managers' perception and the workers' stated preferences. It is important to understand this question in order to help Polish managers manage more effectively, help business investors to understand the environment for their investment opportunities, and to guide the many Western educators who are now trying to help Polish managers learn to manage by adapting theories and practices which work in the West to the Polish situation.

\section{POLAND IN TRANSITION}

In the last three years, tremendous changes have occurred in Eastern Europe and the Former Soviet Union. The fall of communism has stunned not only the West, but the people in these former Iron Curtain countries. Various versions of centrally planned (or command) economies, chosen by the communist leadership, have been discarded. Eastern Europe and the Former Soviet Union have embarked on a journey to a place they have not been to for many decades -- a market economy. All of these countries see a variant of a Western-style free market economy as their future economic system.

The people of these countries face the prospect of increasing poverty. There is a scarcity of disposable income to buy goods and 
services. National income in Eastern Europe fell by over $11 \%$ in 1990 , while inflation is expected to rise by $28 \%$ in 1991 . Unemployment rates are approximately $15 \%$ and worker motivation is decreasing (Rafalski 1992; Schares, Olsen, Reaves, and Weiner 1991).

In spite of current economic hardships, the people of Eastern Europe remain hopeful. Many people in former communist countries believe (or believed) that to make their economies and enterprises successful and increase the standard of living for everyone in their country, all that is needed is to implement the principles and theories that have developed in the West. What's not often recognized is that this extends to the practice and theory of worker motivation.

The market opportunity for Western businesses in this region is enormous. Capitalists are lured by low wage rates, an educated work force, and a market of over 150 million consumers in the heart of Europe plus an additional 275 million potential customers in the Former Soviet Union. According to one analyst, "learning how to invest profitably in Eastern Europe is the hot new game of the 1990s" (Greenwald 1990: 8). However, the road to cracking these potentially lucrative markets has obstacles, not the least of which is the successful transition to a free market economy and the required worker motivation and productivity.

Poland has been among the most aggressive countries in the transition to a free market economy, embarking upon dramatic economic changes. For the past five decades Poland has been operating in a centrally planned economic system with dismal results. The peaceful overthrow of the communist party and the desire to 
quickly increase the standard of living has led the country to take major steps toward a free market economic system.

On January 1, 1990, the new non-communist government instituted many free-market reforms. Prices immediately rose and unemployment became a reality. This "shock treatment" has been an unplanned approach causing Polish business managers to operate in a new market environment virtually immediately.

Today, the Polish economy is plagued by unemployment (15\%), low wage rates (about $\$ 175$ per month average), high inflation (about $45 \%)$, poor equipment, and workers whose motivation toward productivity and quality is less than that of their Western counterparts. Although Poland's political and social systems are more stable than most other former communist countries, these systems are considerably more unstable than those of its Western counterparts. The Polish people expected a much easier time in the transition to a free-market economy and are impatient with the changes and hardships (Hess 1991, Rafalski 1992, Economist 1991). A joke often quoted (with more than a grain of truth) states that Poles want to work like Socialists and live like Capitalists.

\section{RESEARCH QUESTION}

The success of the Polish transition is a complex systems issue requiring consideration of a wide variety of elements. This Systems Science Business Administration dissertation will concentrate on one of the key areas to consider -- the workers' and managers' job attribute preferences with a focus on motivation. Two systems sciences' 
approaches were used to analyze and refine the research questions: multiple perspectives of Linstone (1984), a horizontal view; and the systems approach of Lendaris (1986), a vertical approach.

This study lays the foundation for implementing effective motivation plans and to guide managers in their motivational behavior with their workers. Specifically, this dissertation will answer these questions:

1. What do Polish workers and managers want from their work?

2. Do Polish managers accurately perceive the job attribute preferences of their workers?

3. Do Polish worker and manager job attribute preferences differ from their United States counterparts?

4. How do key organizational (supra-system) and individual variables influence worker and manager job attribute preferences?

These research questions deal primarily with individuals, organizations, and the interaction of individuals within organizations. In addition, the environment in which these interactions occur includes an entire national and society in fundamental political and economic transition. The very nature of these entities and their interactions is complex. Often, systems science theories and approaches help the researcher clarify these types of problems in formulating appropriate research questions.

Lendaris (1986) described the perceiving role of the researcher ("systems practitioner") in the act of defining the system under investigation. Specifically, he introduced the concept of different perception levels: the system (unit under investigation), the subsystem (the elements that make up the system), and the supra-system 
(the environment in which the system operates). Lendaris (1986) advised role-playing a variety of perspectives ("beholder roles") in the process of attaining a better understanding of a complex problem or research questions.

The "system" under investigation is the Polish enterprise and the primary research question of this dissertation is the mismatch between managers' perception of workers' job attribute preferences and the workers' stated job attribute preferences within the Polsih firm. This "system" is discussed throughout Chapter II and in particular, the section on "Mismatch of Job Attribute Preferences."

The "sub-systems," which include the personal behavior and personality characteristics of the individual workers and managers, existing company motivational policies, and perhaps job content, are discussed in Chapter II.

The "supra-system" is the environment for this interaction and is primarily the organization or enterprise and to a lesser extent, the Polish social and economic systems. The "supra-system" is discussed in Chapter II in the sections "Poland in Transition," and "The Organization (Supra-system) Influence on the research question (System)."

A researcher (in this case, systems practitioner), should take various perceptual stances to ensure that the problem definition or research question is appropriate. First, acting as the beholder of the "supra-system" and "system," this researcher considered how the motivational issues relate to the company or organization. Chapter I discusses how motivation and the interaction of the manager and 
worker (system) would affect the company (supra-system) and vice versa. One issue that arises from this "beholder" position is the potential conflict or biases that might occur at the boundary between the individual and the organizations. The classical question is whether the researcher is collecting data on the research question (real and perceived personal preferences) or are the data contaminated from the organizational system. The Limitations section of Chapter III discusses this in more detail.

Another beholder position is to view the motivational issues at the sub-system level -- personal motivation of the workers and managers, etc. These ideas are discussed in Chapter II dealing with worker and manager motivation. One issue that arises from this beholder position relates to another classical question: is the researcher collecting data on the research question (real and perceived personal motivation) or are the data contaminated by the personal characteristics of the individuals. Although this is discussed somewhat in the Limitations section of Chapter III, the psychological nature (persona) of individuals is beyond the scope of this research. Indeed, Freud's Interpretation of Dreams (1926) discussed the three layers of the individual: professional, political, and persona, and pointed out that the persona is the least accessible and understood.

Linstone (1984) introduced the concept of multiple perspectives to ensure that the researcher clearly separates the two questions: "What am I looking at?" and "How am I looking at it?" He pointed out that viewing the research question or problem from 
multiple perspectives often yields new insights, simplifies complex problems, and clarifies conclusions and recommendations.

The three perspectives are described in an example of an organization that may be viewed through three filters (Linstone 1984: 47):

Technical (T) the organization could be viewed as a hierarchical structure to be modeled using system dynamics and applying decision analysis.

Organizational $(O)$ the organization could be considered powerful or weak; a living system, fighting competition with a strong staff and weak line.

Personal (P) the organization could be viewed as job security, an opportunity to exert power, or a step to gain prestige.

The author (as a rational analyst) used these three perspectives extensively to help in defining the research questions, presenting the hypotheses, designing the data collection, collecting the data, and offering potential explanations, conclusions and recommendations. A further explanation and some specific examples follow.

The $\mathrm{T}$ - perspective yields a view of the dissertation from a critical scientist's point of view. For example, the researcher must analyze the data appropriately, recognize and clearly discuss the limitations of the study, identify future possible research areas, etc.

The $O$ - perspective yields knowledge of motivation and perceived job attribute preferences that could affect motivational plans, etc., resulting in increased worker satisfaction and ultimately better company performance. The 0 - perspective also has alerted the 
author to the possibility that managers may want workers' answers to match existing motivational schemes.

The $\mathrm{P}$ - perspective yields an explanation and rationale for the results of individual workers and managers (why they chose certain rankings, etc.). In addition, this $\mathrm{P}$ - perspective ensured that the author viewed the research question, data collection process, and results, from the individual worker and manager perspective yielding clearer hypotheses, appropriate questionnaires, and insightful conclusions and recommendations. The $\mathrm{P}$ - perspective also alerted the author to the possibility that workers may tend to give answers which match their managers' expectations.

A somewhat modified multiple perspective approach was recommended by Schein (1980) for a similar research question, but looked at motivation and worker/manager relationships from three viewpoints: the individual employee (P), the manager of the organization ( $\mathrm{P}$ and $\mathrm{O}$ ), and consumer (probably $\mathrm{O}$ ). He also pointed out a need for a socio-cultural/situational perspective (viewing the system at a higher level).

\section{IMPORTANCE OF THE RESEARCH QUESTION}

This research is important for the following fundamental reasons. The research will

1. Extend and broaden the theory and research about job attribute preferences.

2. Help managers in Poland (and their Western partners) to better understand their workers' job attribute preferences. This could help managers in transitional economies develop 
better motivational policies, and in a larger sense, contribute to a successful transition to a free market economy.

3. Break new ground in attempting research in and about enterprises in a transitional period from centrally-planned to free-market economies. Many of these economies are at a point in history never to be repeated.

The following is a brief description of each of the these three areas. The theory and research regarding job attribute preferences will be extended and broadened in a number of important ways. The research will introduce new models and expand the data related to job attribute preferences (e.g., importance ratings and richer demographic data). Analyzing workers' attitude regarding their personal economic situation as a moderating effect on job attribute preferences will be done for the first time. Job attribute preferences of Polish workers will be compared with those of other countries and in other economic and social circumstances.

The idea of job attribute preferences will be put into a larger context in two ways: (1) a new (or modified) motivational model with parallels in marketing is introduced, and (2) job attribute preferences are analyzed using an existing work-motivational theory, helping to clarify this research direction, particularly as it relates to motivation.

The second area of importance is the social and economic benefits to transitional economies in Eastern Europe, particularly Poland. At a time when Polish industry is handicapped by poor equipment and technology, the human resources of this country need to perform at a very high level to make the enterprises and the nation successful. In order for this to happen, managers of these enterprises need to know what their employees and workers want from their job 
experience. Managerial policies and plans designed to influence the motivation of workers need to be based on data, not assumptions. about worker job attribute preferences (Eder 1988).

Relative to their U.S. counterparts, Polish managers historically gave limited attention to the job attribute preferences and motivation of their workers. Without confronting potential managerial misperceptions regarding what workers want from their job experience, historic stereotypes will persist and the design of new motivational systems will remain sub optimal.

The potential mismatch between Western management thinking and the socio-cultural context of Eastern Europe is also important to address. To be successful in joint ventures and other business dealings, American or Western business managers need to know how Polish people are motivated and in what ways Polish workers differ from Western workers in what they want from their job experience. Another important reason for this research is to assist Western and Polish business educators in their task of training and educating Polish managers. Educators face unique challenges because of the lack of cultural understanding in many areas, including management philosophy regarding motivation and worker's needs (Madhavan and Fogel 1992). Initial efforts at educating managers in Eastern Europe have been criticized for not modifying Western management practices for the "local situation."

In some people's view, the success of Poland will dictate success in other former-communist countries. One observer's opinion is as follows: "If Poland is not successful with its reforms, no other post- 
communist country will be successful with its reform and half of Europe will go back to communism" (Rafalski 1992).

The third important area is the situational and temporal environment of the research itself. The author knows of no other such research attempted at this stage in a transitional economy. Obstacles regarding data collection, cultural and language translations and applicability, and enterprise selection, operational arrangements and sampling will have to be overcome for perhaps the first time. In addition, the data is time-sensitive; that is, the research will be done at one point in time in an economy that is in rapid transition. The extension of the results into the future should help researchers develop theories of new economic transformations in other countries. 


\section{CHAPTER II}

\section{REVIEW OF THE LITERATURE}

The purpose of this literature review is to ascertain ideas and theories applicable to the research questions and methodology. This chapter starts with an introduction of a model that connects the motivation process and the role of data on job attribute preferences. This new model uses a generalized model of the motivation process and other models from marketing processes. Next, a systems model of the variables affecting the motivational process in organizational setting is discussed and reviewed in-depth. An historical review of Polish management practices and behavior follows, including a discussion of applicable corresponding Western practices and behaviors. The chapter concludes with a list of all of the hypotheses.

GENERALIZED MOTIVATION PROCESS MODEL INCLUDING THE ROLE OF DATA ON JOB ATTRIBUTE PREFERENCES

This dissertation focuses on job attribute preferences and does not deal directly with motivation. However, job attribute preferences are indirectly linked to motivation (or should be). This section discusses motivation models and shows graphically where job attribute preferences are linked to motivation using marketing models.

Although there are many different definitions of motivation, Steers and Porter 1991 pointed out that the basic building blocks of a 
generalized model of motivation are the same for all models and include (1) needs or expectations, (2) behavior, (3) incentives or goals, and (4) some form of feedback. Dunnette \& Kirchner's (1965) model for the interaction of these variables is shown in Figure 1.

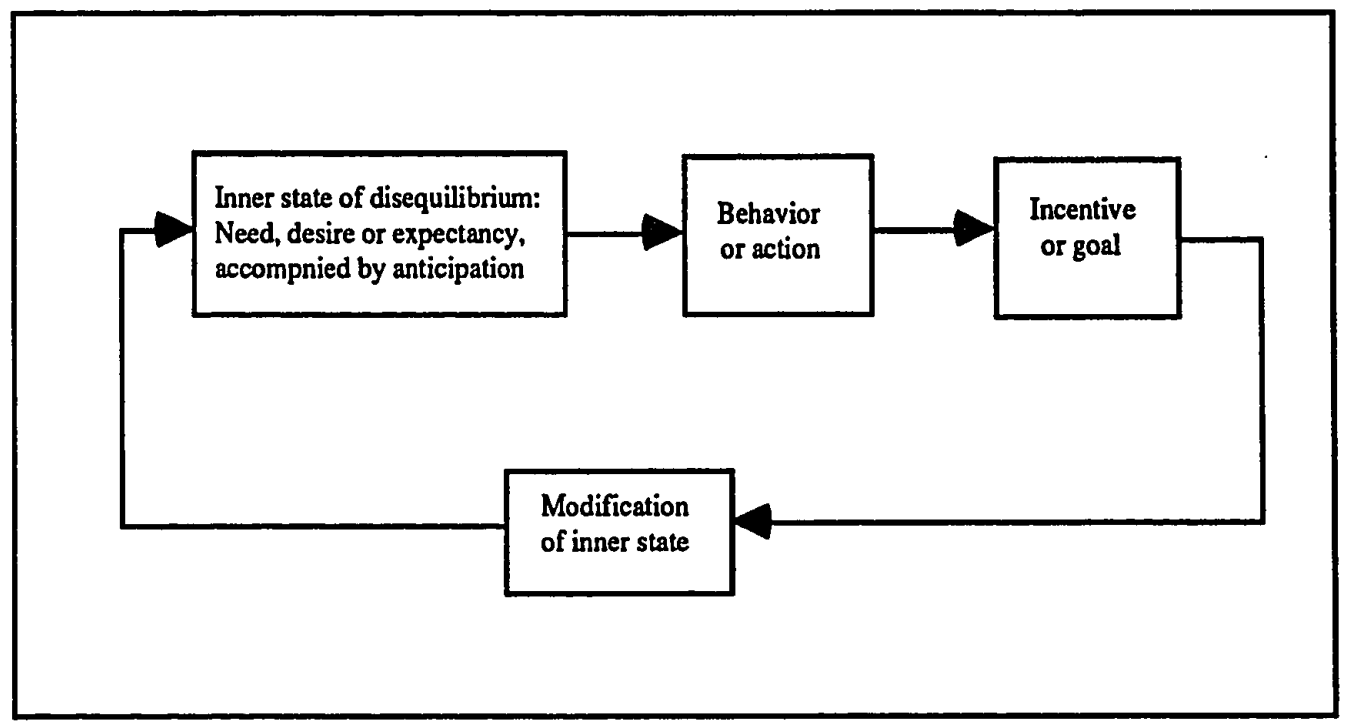

Figure 1. A generalized model of the basic motivation process. (Steers \& Porter, 1991: 6, after Dunnette \& Kirchner, 1965)

A parallel model for the customer purchase process in marketing can be developed (Kotler 1992, and Peter and Olson 1990). The basic building blocks for such a generalized model could include (1) needs or expectations of the customer, (2) action or buying behavior of the customer, (3) incentives in terms of product benefits, and (4) some form of feedback such as customer satisfaction of need or expectation. The interaction of these blocks in the form of a marketing model (customer purchase process) can be depicted as in Figure 2 below. 


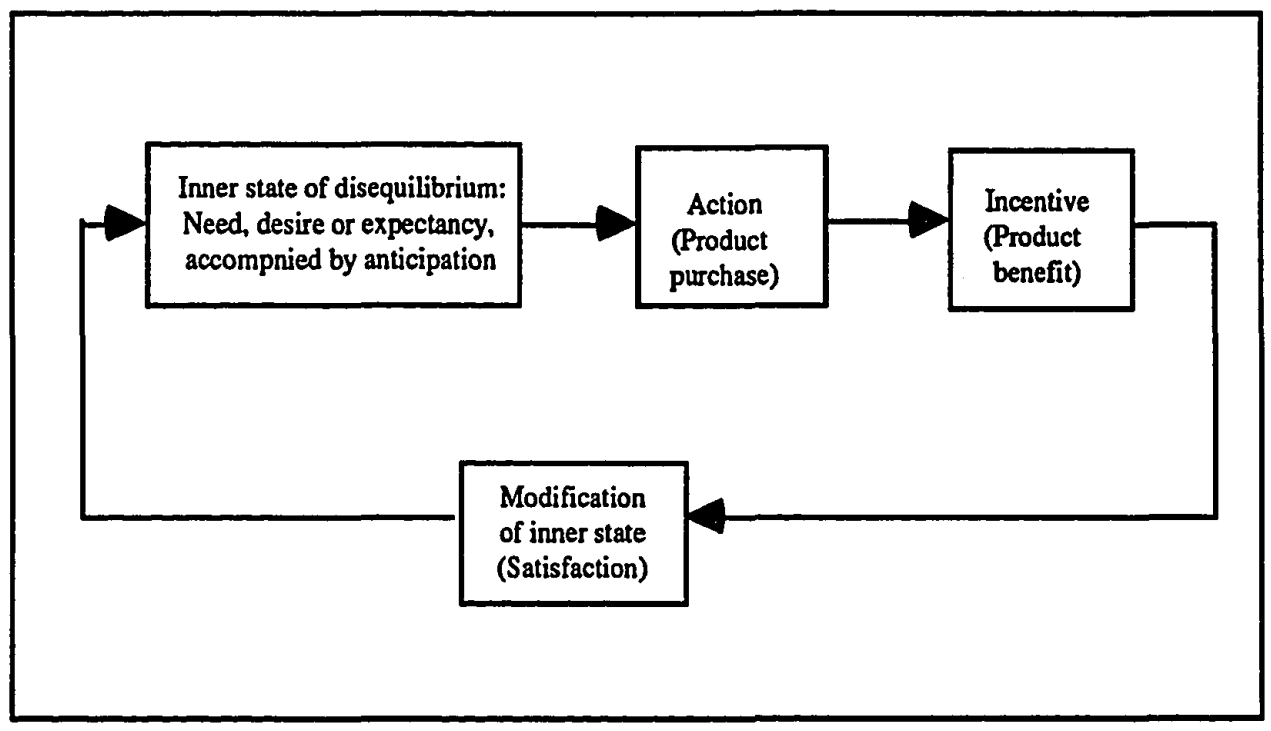

Figure 2. A generalized model for the customer purchase process.

Taking a systems view of this basic customer purchase process, it is necessary to move up one or two levels to include (a) the actions by marketing management because they have primary responsibility for the product, and (b) the corporate organization because they set the overall goals and policies that influence marketing policies.

Thus, the models described in Figure 1 for motivation and Figure 2 for marketing are not adequate because both models approach behavior from strictly an endogenous or $\mathrm{P}$ - perspective. In fact, the design of products that satisfy customers' needs are influenced by data from marketing research activities regarding those needs and the design of motivation systems that meet workers' needs are influenced (or should be) by data from researching activities regarding workers' needs or job attribute preferences. Hence, there is a need to move up a level and modify these models to include a 
systems-level-spanning activity (data collection regarding needs and preferences). These modified models are presented in Figure 3 and 4 and described below.

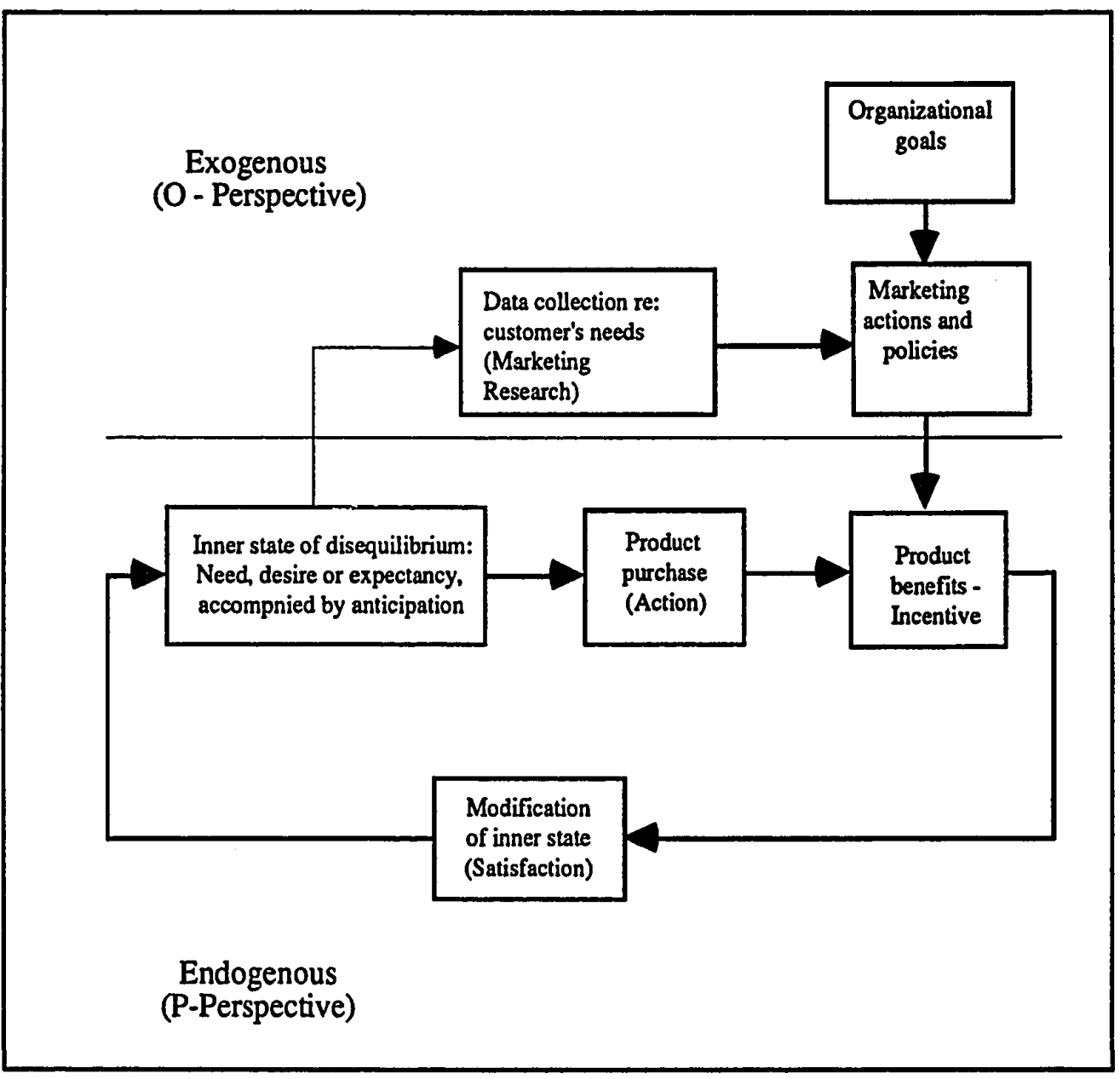

Figure 3. A generalized model of the basic customer purchase process with marketing management influence.

The modified consumer purchase model in Exhibit 3 positions organizational goals and policies as the driving force for marketing actions and policies which in turn, influence the product and product benefits. The model also recognizes another important influence on 
marketing -- the required data collection regarding customer's needs using marketing research techniques.

Figure 4 presents a generalized model of the basic motivation process modified to include the role of job attribute preference research. This model, which combines the marketing model in Figure 3 and the generalized motivation model of Figure 1, shows that the process of collecting data regarding job attribute preferences is similar to the marketing research process used to collect data on customer needs. This new model clearly shows where the data for job attribute preferences and how organizational environment and management policies fits into the basic motivation process.

A SYSTEMS MODEL OF THE VARIABLES AFFECTING THE MOTIVATIONAL PROCESS IN ORGANIZATIONAL SETTINGS

The most striking aspect of the study of work motivation is the all-encompassing nature of the topic. Porter and Miles (1974) discussed a comprehensive theory of motivation at work and addressed three important sets of variables on three levels of organizational settings that constitute the work situation. Their work is summarized in Table I below (from Steers and Porter 1991:20).

This model can be seen to constitute a system in the vertical sense described by Lendaris (1986). The lowest level and one of the subsystems of the organization's motivational system addressed in this 


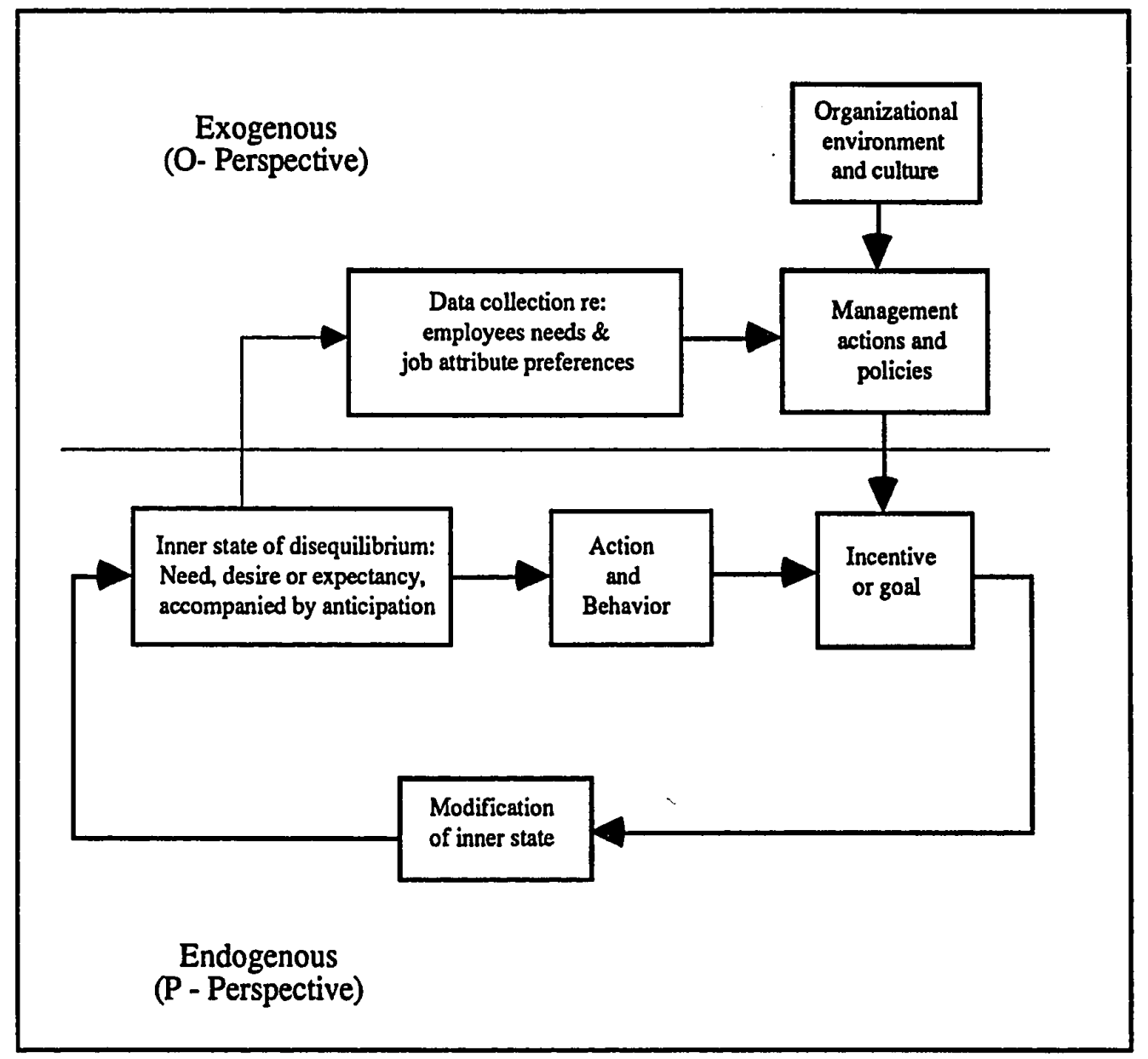

Figure 4. A generalized model of the basic motivation process modified to include the role of job attribute preference research. 
TABLE I

VARIABLES AFFECTING THE MOTIVATIONAL PROCESS IN ORGANIZATIONAL SETTINGS

\begin{tabular}{|c|c|c|}
\hline Individual characteristics & $\begin{array}{l}\text { Job characteristics } \\
\text { (examples) }\end{array}$ & $\begin{array}{l}\text { Work environment } \\
\text { characteristics }\end{array}$ \\
\hline $\begin{array}{l}\text { Interests } \\
\text { Attitudes (examples) } \\
\text { Toward self } \\
\text { Toward job } \\
\text { Toward work situation } \\
\text { Needs (examples) } \\
\text { Security } \\
\text { Social } \\
\text { Achlevement }\end{array}$ & $\begin{array}{l}\text { Types of intrinsic } \\
\text { rewards } \\
\text { Degree of autonomy } \\
\text { Amount of direct } \\
\text { performance feedback } \\
\text { Degree of variety in tasks }\end{array}$ & $\begin{array}{l}\text { Immediate work } \\
\text { environment } \\
\text { Peers } \\
\text { Supervisors } \\
\text { Organizational actions } \\
\text { Reward practices } \\
\text { System wide rewards } \\
\text { Individual rewards } \\
\text { Organizational climate }\end{array}$ \\
\hline
\end{tabular}

dissertation is the individual characteristics of the worker including interests, attitudes, and needs. The next systems level, job characteristics is examined in this dissertation through job characteristics including types of intrinsic and extrinsic rewards (interesting work, good pay, etc.). The supra system is the work environment characteristics including the immediate work environment (e.g. peers, supervisors) and the organizational actions (reward practices, system wide rewards).

In addition, there is a level of the system, not included in Table I -- the external environment characteristics, beyond the bounds of the organization. This level can include political, cultural, socionormative, demographic, and economic issues. These areas are very important in the case of today's Poland because of the continued social and economic turmoil during Poland's transition to a free market 
economy. New realities coexist with old laws that impact the organization's ability to motivate workers. Two examples that often constrained and confused Polish managers are as follows: (a) in order to control inflation, state firms were ordered to pay a $500 \%$ tax on all pay increases after 1990 as a form of wage control; and (b) the state dictates the benefit package for all Polish workers in both state or private enterprises. Therefore, it is important to view these various levels of variables, not as static, independent items, but interactive sets of variables operating to drive worker motivation (Steers and Porter, 1991:575).

This dissertation focuses on the above set of individual variables by directly inquiring about workers' job attribute preferences and at the same time gathering information at the organizational level, all done with an appreciation of the macro Polish situation.

Ideally, worker motivation would be managed in a customized manner. For example, for one person, a bonus plan would be the best motivating policy; for another person, job rotation would be best. The reality is that organizations value consistency and are not capable or willing to offer individual motivational systems for each worker. Rather, management develops an array of policies that best meet the widest range of workers' needs (the supra system or $O$ - perspective influence). It is therefore important to assess collective perceptions that managers have of their workers' job attribute preferences. 


\section{POLISH MANAGEMENT PRACTICES AND BEHAVIOR -- A REVIEW}

Because of the major economic revolution in Eastern Europe and Poland, management and business history in these countries are considerably different from current Western practices. Thus, it is important to review the management practices and behavior during the communist leadership and planned economic system, particularly in Poland.

There has been much written about Poland's archaic technology and manufacturing methodologies and not very much about their management practices (Rafalski 1992, Schares, Olsen, Reaves, and Weiner 1991). However, there is little material in the literature regarding Polish management practices, and what is available comes from studies in the 1960s and the 1970s.

In the U.S., many managers have made the transition from Theory X to Theory Y (McGregor 1960) and the best managed firms have gone beyond Theory $\mathrm{Y}$ toward more consultative, organic management styles (Peters and Waterman 1982). The situation differed considerably in a planned economic system such as Poland. Significant top-down forces were evident. There were formal decrees regarding the manager's responsibility towards subordinates. Feiwel (1965: 197) pointed out that managers had to sign an agreement which stated "He (the manager) is to be obeyed by his subordinates in accordance with the principle of the one man management and responsibility." Falus (1972: 83) refers to an oath which all managers had to take: " ... I swear to obey my superiors in office, to preserve professional secrets and to discharge my official duties precisely and 
conscientiously, keeping in sight the interests of the people." The director who was accused of breaking a regulation could be dismissed and imprisoned for up to five years (Feiwel 1965)! With this strong autocratic style required in a planned economy, very few Polish managers got past the Theory X model of management.

With communist control, Poland functioned under a centrally planned, highly regulated economy. Such a system created an atmosphere of distrust and suspicion, causing people to become inhibited. Polish business people became accustomed to covering up and concealing information. Workers in this "upward oriented" environment, had to satisfy the needs of the manager. Supervisors and managers had no need or responsibility to look "down" and satisfy the needs of employees (or customers). If a worker made management look bad, it could be interpreted as being disloyal and against the communist party (Feiwel 1965).

A key element in producing competent managers is the selection process. U.S. managers are promoted primarily because of their ability to meet business objectives, as determined by a Board of Directors or other senior managers within the firm. Polish Managing Directors (Presidents) were often selected by the Ministries (Feiwel 1965). Other Polish managers were chosen (and are still chosen today) by a democratic vote of the workers or workers' council. Performance is reviewed by the workers annually and the workers decide if the manager stays for another year. This has produced business leaders with strong political skills, but questionable business acumen. In fact, this system works against action on one of Poland's 
biggest business problems -- over-staffing. How can today's Polish business leader reduce staff when the same staff will vote on his tenure with the firm?

Other key ingredients needed to compete in a free-market economy are innovation and risk taking. Today's competitive situations force managers to operate in an arena requiring new ideas and approaches and quick reactions to competitive moves. Poland's managers have been brought up in a world where risk taking was rejected and innovation often questioned and unrewarded. It is unlikely that individuals with these characteristics have been in the wings within Polish firms waiting for top management to be toppled and a new economic system installed. These characteristics must be developed over a long time with a fertile supportive environment. Many innovative risk takers have long-ago left the country.

Work in a capitalistic system carries different meanings and many opportunities for motivation and rewards. The Protestant Work Ethic sees work as a route to salvation. Work is also viewed as the primary source of one's identity, personal satisfaction, and leisure. Capitalism ties the work ethic to wealth production and develops personal initiative. Thus, western work activities provide an opportunity for a rich blend of intrinsic and extrinsic motivation.

In contrast, communism has the system itself as the "owner" of the goods, services, and social services. Work and income in a communist society are considered social versus economic benefits. Workers and managers develop a work ethic of survival and personal welfare, limiting managers' motivational policies to extrinsic rewards. 
With this cultural and social background, training Polish managers to run companies in a free market economy will be very difficult. Western based theories may have to be modified to match this unique environment. Naumienko \& Dlugosz (1989) referred to Polish managers suffering from "a barrier of routinized perception" (stuck in a "twilight zone" of past behavior and thought without selfanalysis and questioning). Naumienko \& Dlugosz (1989) believed that Polish managers would inappropriately continue to apply their old patterns to the new economic conditions.

Jenner and Gappa (1990) conducted a study of businesses in Poland exploring the abilities of Polish managers to adapt to the requirements of a competitive market economy. They discovered that managers adopted a more or less passive attitude toward many things including the potential collapse of their markets. Although all of the companies had learned the basics of subjects like marketing, most of them hadn't even started to do any marketing in their enterprises.

Managers' jobs were defined by state and workers' council directives which had to be obeyed and there were strong consequences for disloyalty. In 1965 there were 19 specific state directives (Feiwel 1965). The complete list of directive topics is presented in Appendix A. None of these topics relate to the human resource management responsibility of managers. One director was quoted as saying,

The association (directives) has most effectively broken our habit of independent thought and action. Productivity, wages, and labor intensity are established for us, leaving us only the execution of the plan. In such a state of affairs the director (and therefore the workers too) does not feel any 
responsibility for the enterprise, he is only concerned with the fulfillment of the plan. (Feiwel 1965: 209)

Managers learned how to manipulate the system and "play the game" -underestimating and under-reporting costs was a recognized skill. Bribes and other illegal activities were the norm (Feiwel 1965).

Zielinski (1973: 123) listed 46 additional "Bonus Tasks" (directives tied to financial rewards), none of which had anything to do with human resource management. In fact, even the vocabulary supported the idea that the workers were considered machines. For example, Zielinski (1973: 150) used the sentence. "The role of the management mechanism in socialist industry is ... to stimulate plan executants to economic behavior both within the process of plan fulfillment and outside it." It appears paradoxical that a system designed to make workers the center and equal to all, defined management responsibilities devoid of attention to the needs of workers.

In summary, ministries in the centrally planned Polish system dictated virtually all of the elements required to manage a business including motivational policies that were strictly extrinsic. Very little research was done on worker and manager motivation in Poland during this period because it was irrelevant to the "system."

\section{POLISH WORKER MOTIVATION}

As with management practices, there is little material in the literature regarding Polish worker motivation, and what is available comes from studies in the 1960s and the 1970s. Ronen's (1986) comprehensive work summarizes the results from hundreds of studies 
on cultural and multinational motivation and highlights the lack of studies in the then-Communist world. He found nothing in the literature to report.

Similar to Polish manager motivation discussed above, workers were also motivated primarily by bonuses and incentives. In fact, the calculations were very elaborate and detailed (for example, .05\% per ounce of cotton shipped). Premiums for inventions and improvements were also used extensively. However, these incentives were often distributed to large groups, making the effect on any one individual very small. Premiums paid by buyers to their suppliers (bribes) for above plan performance were quite frequent (Feiwel 1965).

Kolaja (1960) interviewed 24 workers in 1957 using a questionnaire to access their "future aspirations." A large percentage of the group wanted a new apartment (62.5\%) while $37.5 \%$ preferred a raise. More than half $(55 \%)$ of the workers seemed to be satisfied with their work and wanted to keep their same job and a little less than half (45\%) wanted to change. Of the 11 who wanted a change, four wanted to be a foreman, one wanted a white-collar job, and three did not want to work at all. The answers to the question of what workers would do if they won a lot of money are listed in Table II (Kolaja 1960).

Kolaja's work shows a motivational picture heavily weighted towards extrinsic characteristics and basic, low level needs. This could be explained by Maslow's hierarchy of needs (Maslow 1970).

Maslow's theory of needs (Maslow 1970) and other related theories (Herzberg 1966, McClelland 1962) stated that individuals 
TABLE II

WHAT POLES WOULD DO WITH "LOTS OF MONEY"

\begin{tabular}{|l|c|}
\hline \multicolumn{1}{|c|}{ Item Wanted } & Frequr .cy \\
\hline New clothes & 11 \\
\hline New apartment & 5 \\
\hline Motorcycle & 2 \\
\hline Build a house & 2 \\
\hline New furniture & 1 \\
\hline Food & 1 \\
\hline Drugs & 1 \\
\hline Save it for the future & 1 \\
\hline
\end{tabular}

who have lower level unsatisfied needs (physiological) will seek to satisfy these deficiencies before considering higher level needs (selfactualization). Maslow (1970: 36-37) stated:

Undoubtedly these physiological needs are the most prepotent of all needs. What this means specifically is that in the human being who is missing everything in life in an extreme fashion, it is most likely that the major motivation would be the physiological needs, rather than any others. A person who is lacking food, safety, love, and esteem would most probably hunger for food more strongly than for anything else.

A model which matches Maslow's hierarchy of needs with job attributes is shown in Table III (Schein 1980: 86).

This theory suggests that Polish workers, who are now having trouble making enough money to satisfy their basic living needs 
TABLE III

A MATCH OF MASLOW'S HIERARCHY WITH JOB ATTRIBUTES

\begin{tabular}{|l|l|}
\hline \multicolumn{1}{|c|}{ Maslow Needs Hierarchy } & \multicolumn{1}{|c|}{ Job Attributes } \\
\hline Physiological & Working conditions \\
\hline Safety & Salary \& benefits \\
\hline Affiliation & Fellow workers \\
\hline Self-esteem & Recognition, advancement \\
\hline Self-actualization & Job challenge \\
\hline
\end{tabular}

(physiological) may have job attribute preferences tied to lower level needs such as work conditions, salary and benefits. It is also plausible that the workers' managers, who make only slightly more money than their employees, will have empathy with their subordinates (self reference) and have less of a mismatch in their view of workers' job attribute preferences.

Initial theories of worker motivation assume that workers have a psychological contract which reflects the prevailing assumptions about the legitimate bases of authority. The rational-economic assumptions include the following (Schein 1980: 52):

- People act to maximize their self-interest.

- The organization buys the services and obedience of the employee.

- If productivity is low, management reacts by trying new incentive plans and bonuses. 
- The burden of performance falls entirely on management. Employees are expected to do no more than the incentive and reward system encourages and allows.

This Theory X-like model, which emphasizes extrinsic motivation, may match the literature description of management/worker models in effect in most Polish enterprises.

The more modern view of worker motivation includes these assumptions (Schein 1980: 52):

- Human motives fall into a hierarchy of categories - Maslow (1960).

- Individuals seek to be mature on the job - autonomy and independence.

- People are primarily self-motivated and self-controlled.

- There is no conflict between self-actualization and effective organizational performance; the individuals will integrate their goals with the organization.

This Theory Y-like model assumes that management must make work intrinsically more challenging and meaningful. The basis of motivation shifts from being extrinsic to intrinsic -- participative management. There appears to be no evidence of this management philosophy in Polish enterprises today or in the past.

The Polish people have a much lower standard of living than individuals from western countries and are still motivated to fulfill lower level needs. From the above data it could be concluded that the Polish people have had their physiological needs satisfied. Indeed, even under communist rule, $75 \%$ of all farms were privately owned and food was relatively plentiful. The Polish people appear to have 
unsatisfied safety needs evidenced by desires such as shelter (e. g., apartments and cloths).

Kozminski's (1971) work depicted a more recognizable and Western-like picture of motivation in Poland. He stated that the most important rewards (in the late 1960s) were primarily extrinsic: job security, amount of salary, power exercised, prestige acknowledged by formal and informal groups. However, Kozminski (1971: 67) pointed out that "intuitively, and through observation," real motivation diverges considerably from what might be inferred from this description of rewards. He discussed examples of commitment to work independent of the reward (intrinsic). However, he pointed out that this is an area where knowledge is very limited, but where it would be "imprudent to transplant conclusions from studies analyzed elsewhere -- and especially from those conducted in capitalistic countries" (Kozminski 1971: 68). Kozminski (1971) also stated empirical research on this subject is needed.

The two key methods of motivation were (1) constant reminders of party allegiance (e.g. posters on the wall with slogans expecting hard work), and (2) bonuses related strictly to economic performance (Feiwel 1965). Slogans, banners, exhortations, and "best worker" billboards were frequently used to try to motivate workers and maintain communist order. However, it is not clear if the exhortations of the party ever did any motivating, or ever had any effect (Kolaja 1960, Feiwel 1965).

In this environment, managers spent little time trying to understand $t^{\circ} i c$ true motivation and job attribute preferences of 
workers (Feiwel 1965). A paradox existed in which a society theoretically based upon equality, particularly for the worker, assumed that the worker was motivated primarily, perhaps exclusively, by pay and outward exhibition of allegiance to the party (extrinsic factors). If this management assumption continues today, the result can be continued worker-management conflicts, higher labor costs, plant closures with high unemployment and civil unrest, thereby contributing to the collapse of the free-market movement.

It is important to recognize that the prime change agent for the 1989 revolution in Poland was the formation and activities of Solidarity. Although there is nothing in the literature discussing the Solidarity movement and worker motivation, it should be pointed out that Solidarity was a worker-based movement. Workers were fed-up with their economic plight and insisted on changes, even in the face of imprisonment and death. This shows that Polish workers had courage, tenacity, and were strongly motivated for change. The movement was driven by personal economics and decreasing standard-of-living, exclusively extrinsic issues. This appears to reenforce the theory that Polish workers are in the lower levels of Maslow's hierarchy.

Today, with unemployment in double digits, income well below American poverty levels, Western goods priced at Western prices, and high inflation, the Polish worker may not be better off and constantly has to worry about the basics of living (Economist 1991; Rafalski 1992; Schares, Olsen, Reaves, \& Weiner 1991; and personal conversations with Polish individuals, 1992). There are some new entrepreneurs 
and private firms which pay more money, but even the highest paid workers earn less than $\$ 500$ per month (Personal conversations with Polish companies, 1992). Although the United States is currently in a recession, the average American worker is much better paid and is at a higher standard of living.

In conclusion, it could be expected that the average Polish worker would be more motivated to fulfill lower level Maslow-type needs, yielding a higher ranking (or importance) on extrinsics and a lower ranking on intrinsics than their American counterparts. Thus, the following hypothesis is presented:

$\mathrm{Hl}$ : The job attribute preferences of Polish workers will tend to be more extrinsic and less intrinsic than those of their American counterparts.

Adam \& Piraino's (1978) research supports this hypothesis. They found much greater support for Maslow's theory in Chile than is typical of research carried out in highly industrialized countries. In Chile, there was far less satisfaction of basic physiological and safety/security needs than in the United States and higher motivation to fulfill the lower-level needs (extrinsics) than higher-level needs (intrinsic).

The above hypothesis is for the Polish workers in the aggregate. However, a mitigating factor for individual Poles will be how optimistic or pessimistic they are about their economic situation. As Maslow theorized, the physiological needs are the most prepotent of all needs and an individual who is missing these needs will most likely be motivated to fulfill them, rather than others. A person who is lacking food, safety, love, and esteem would most probably be pessimistic 
about their personal economic situation and would hunger for food more strongly than for anything else. One would expect that workers who tend to be pessimistic about their personal economic situation would have higher extrinsic and lower intrinsic job attribute preferences than those who tend to be optimistic. Thus the following hypothesis is presented.

H2: The job attribute preferences of Polish workers who tend to be optimistic about their economic situation will be more intrinsic and less extrinsic than those of Polish workers who tend to be pessimistic.

\section{POLISH MANAGER MOTIVATION}

There is little information in the literature regarding motivation of Polish managers. Kozminski (1971) recognized the importance of knowing what motivates managers and workers but pointed out that the knowledge of motivation by and of managers was far from complete and stated that empirical research on this subject was needed. "This is an urgent task, for otherwise it will be difficult to explain the conduct of the managers and consciously guide their behavior" (Kozminski 1971: 68).

Through late 1989, Polish Ministries motivated its managers strictly with well tuned financial bonuses. There were financial rewards tied to meeting the directives described above and managers were often encouraged to manipulate the results in order to maximize financial bonuses (Feiwel 1965). Feiwel stated " ... premium maximization seems to be the primary goal motivating economic behavior of management of a state-owned enterprise" (Feiwel 1965: 
212). Due to the size of the premiums, this additional bonus money was a source of power, prestige, and advancement and helped management focus on the completion of the goals directed by the state.

Kozminski also discussed four major areas of motivation for managers which included a familiar (to U.S. findings) mix of intrinsic and extrinsic motivators:

- Career: promotions and staying in the role of manager ( $\mathrm{mix}$ of intrinsic/extrinsic)

- Recognition for themselves and the enterprise (primarily extrinsic)

- Rewards: maximize their bonuses (extrinsic)

- Fulfillment of a "social mission" (primarily intrinsic)

The same theory regarding Polish workers' extrinsic job attribute preferences should apply to Polish managers. From a hierarchical needs point of view, Polish managers are in the same situation as workers. For example, the pay differential between workers and managers has been and currently is very small (managing directors in Poland -- Presidents -- make about twice as much as workers, versus U.S. presidents making 20 times or more than their workers). Thus, Polish managers are experiencing the same personal economic shock as workers (Feiwel 1975 and personal conversations with Polish companies, 1992). At about $\$ 400$ per month income, with Western goods priced at Western prices. Polish managers have to worry about day-to-day living expenses. Thus, the following 
hypothesis, which is the same as hypothesis 1 for workers, is presented:

H3: The job attribute preferences of Polish managers will tend to be more extrinsic and less intrinsic than those of their American counterparts.

\section{MISMATCH OF JOB ATTRIBUTE PREFERENCES}

A prime focus of this research is the determination of potential mismatches or gaps between what managers think workers want in their job (i.e., job attribute preferences) and what workers say they want. There have been only a few applicable studies reported for U.S. workers and managers, even fewer for other countries, and nothing for Poland. The literature is discussed in the following order: United States, Other Countries, Poland; then hypotheses are presented.

\section{Mismatch of Job Attribute Preferences in the United States}

Much has been written about the American manager's job and their skills in human resource management. Research indicates that they spend most of their time interacting with others -- motivating, reinforcing, allocating formal rewards, asking for input, conveying appreciation, giving credit where due, listening to suggestions, giving positive feedback, group support, resolving conflict (Mintzberg 1973 and Luthans 1988). Research reports that the manager's most important goal, regardless of the manager's age, gender, educational level or position in the hierarchy, is organizational effectiveness, followed by high productivity (Mintzberg 1973 and Posner \& Schmidt 1984). 
However, many Americans freely admit that they are holding back from their jobs -- they are giving less than they are capable of giving to their jobs (Yankelovich \& Immerwahr 1983). Less than a quarter (23\%) of Americans say they are working at full capacity. Similar to Polish workers, a large percentage (44\%) of Americans say that they do not put a great deal of effort into their jobs over and above what is required by management (Yankelovich \& Immerwahr 1983).

Yankelovich \& Immerwahr (1983: 16) discussed a major shift in worker motivation. "People need and want money, but money no longer operates as a simple motivator stimulating people to work harder." Yankelovich and Immerwahr (1983) stated that the dominant concept of work throughout Western history has been "Adam's curse" -- work as disagreeable, unpleasant and even degrading. But, now, $73 \%$ of the respondents expressed positive attitudes toward work and $52 \%$ said "I have an inner need to do the very best job I can, regardless of pay." A smaller percentage (21\%) said that "Work is interesting, but I wouldn't let it interfere with the rest of my life; an even smaller percentage (17\%) say they wouldn't work if they didn't have to."

The survey data of Yankelovich and Immerwahr (1983) quantified the mismatch between the reward system and the qualities that job-holders consider important. More than $50 \%$ of the American work force experienced a mismatch between the reward system designed by management and the workers' job satisfaction attributes.

Table IV summarizes the data form Yankelovich and Immerwahr (1983) which dealt with what workers "want more of" versus the more 
basic question of what attributes of the job are important. Generally, people will ask for what they believe management can deliver. In this case, the list of what workers overwhelmingly believed that management could deliver are mostly extrinsic attributes (6 out of the top 8 attributes).

TABLE IV

JOB ATTRIBUTES AND WHAT U.S. WORKERS "WANT MORE OF"

\begin{tabular}{|l|c|}
\hline \multicolumn{1}{|c|}{ Job Attribute } & $\begin{array}{c}\text { Want More of" on Present Job } \\
\text { (Percent) }\end{array}$ \\
\hline Good pay (E) & 77 \\
\hline Recognition for good work (E) & 70 \\
\hline Good fringe benefits (E) & 68 \\
\hline Chance for advancement (E) & 65 \\
\hline Job security (E) & 65 \\
\hline Interesting work (I) & 62 \\
\hline Pay tjed to performance (E) & 61 \\
\hline Job allows me to learn new things (I) & 61 \\
\hline
\end{tabular}

Managerial misperception of worker job attribute preferences may be better understood when viewed in the context of intergroup relations (Eder 1988). Eder (1988) pointed out that opposing groups commonly develop unrealistic perceptions of themselves and the 
other group. For example, Blake, Shepard, and Mouton (1964) made the point that a gap existed between how management views itself and how unions interpret management's intentions and actions. The greatest distortion was the union's perception that management was acting as a "fatherly dictator," wanting to help and nurture while forcing harsh demands.

Jurgensen (1978) questioned 57,000 job applicants from 1945 through 1975 asking them what they preferred and what they thought "others" preferred in a job experience. The results for 1975 are summarized below in Table V. The "Rating" in this table refers to the average rank for each "Job Factor." For example, the average ranking for "Advancement" for the 57,000 job applicants was 3.3. The "Ranking" means the nominal rank determined by the associated "Rating." For example, the nominal rank for "Advancement" came in second relative to the other Job Factors.

Over the 30 years these data were collected, the responses were about the same except for the gradual increase in ranking of "type of work" and the decrease in "security" and "benefits." However, it appears that Jurgensen possibly missed a major move in worker job attribute preferences because 9 of his 10 job factors were extrinsics. Jurgensen may have had his own built in biases that resulted in a "mismatch" similar to the one being studied in this dissertation.

Eder and Tucker (1982) and Eder (1988) studied the gap between workers' job attribute preferences and managers' perception of workers' preferences in two studies with (a) management students as surrogate managers, and (b) with managers and workers in high 
TABLE V

JOB PREFERENCE RATINGS AND RANKINGS OF U.S. WORKERS AND MANAGERS IN 1975

\begin{tabular}{|l|c|c|c|c||}
\cline { 2 - 5 } \multicolumn{1}{c|}{} & \multicolumn{2}{c|}{ Rating } & \multicolumn{2}{c|}{ Ranking } \\
\hline Job Factor & Self & Others & Self & Others \\
\hline Advancement (E) & 3.3 & 3.8 & 2 & 3 \\
\hline Benefits (E) & 6.8 & 5.2 & 8 & 5 \\
\hline Company (E) & 4.5 & 6.8 & 4 & 7 \\
\hline Co-Workers (E) & 6.0 & 7.7 & 6 & 10 \\
\hline Hours (E) & 7.6 & 5.4 & 9 & 6 \\
\hline Pay (E) & 5.6 & 2.1 & 5 & 1 \\
\hline Security (E) & 7.9 & 6.9 & 10 & 8 \\
\hline Supervlsor (E) & 6.3 & 7.4 & 7 & 9 \\
\hline Wype of Work (I) & 3.3 & 4.9 & 2 & 4 \\
\hline
\end{tabular}

technology firms. Eder and Tucker (1982) concluded that the widest disparity between what workers wanted and what managers perceived they wanted from their work was in the area of intrinsic job attributes. Among the most dramatic gaps occurred in "participation" and 
"developing skills" (both intrinsic). When placed in a simulated management position, the students perceived that the job attribute preferences of the workers were substantially different from their own attribute preferences -- extrinsic rewards were more important to workers than to themselves as managers and intrinsics less.

Eder's (1988) study captured the mismatch between practicing high technology managers' perceptions of production line workers' job attribute preferences and workers' actual job attribute preferences. Like the management students above, these practicing managers underestimated the importance of intrinsic job attributes and overestimated the importance of extrinsic job attributes to line production workers.

The sample used in Eder (1988) was drawn from five high technology firms from Phoenix, AZ. Each firm had between 100 and 500 employees with resident production operations in existence for at least three years. Usable survey response rates ranged from 40 to 80 percent across firms, and averaged $65 \%$ for workers $(243 / 375)$ and $87 \%$ for managers (41/47). Eder's (1988) results are summarized in Table VI where lower median rankings mean higher importance.

Workers had their preferences grouped into three clusters of relative importance: (1) highest importance are the extrinsic attributes of good pay and job security, (2) next in importance is a mixture of intrinsic and extrinsic job attributes of chance to develop skills and abilities, interesting work, good pension and benefits, recognition for a job well done, seeing the results of the work. The bottom cluster includes considerable "say" in how the job is 
TABLE VI

U.S. MANAGERS', WORKERS', AND MANAGERS' PERCEPTION OF WORKERS' JOB ATTRIBUTE PREFERENCES

\begin{tabular}{|l|c|c|c|}
\hline \multicolumn{1}{|c|}{ Job attribute } & $\begin{array}{c}\text { Employees want } \\
\text { (n=243) } \\
\text { (mean/relative } \\
\text { rank) }\end{array}$ & $\begin{array}{c}\text { Managers think } \\
\text { employes want } \\
\text { (n=41) } \\
\text { (mean/relative } \\
\text { rank) }\end{array}$ & $\begin{array}{c}\text { Managers want } \\
\text { (mean/relative } \\
\text { rank) }\end{array}$ \\
\hline \hline $\begin{array}{l}\text { Chance to develop skills } \\
\text { and abilities (I) }\end{array}$ & $4.95 / 3$ & $5.56 / 6$ & $5.05 / 2$ \\
\hline $\begin{array}{l}\text { Interesting work (I) } \\
\text { Job in a growing field (I) }\end{array}$ & $5.12 / 4$ & $5.59 / 6$ & $5.34 / 3$ \\
\hline $\begin{array}{l}\text { Seeing the results of the } \\
\text { work (I) }\end{array}$ & $6.23 / 8$ & $6.34 / 7$ & $5.46 / 5$ \\
\hline $\begin{array}{l}\text { Considerable "say" in how } \\
\text { the job is performed (I) }\end{array}$ & $8.45 / 9$ & $8.76 / 10$ & $6.22 / 9$ \\
\hline $\begin{array}{l}\text { Participation in business } \\
\text { decisions (I) }\end{array}$ & $8.62 / 10$ & $9.90 / 11$ & $6.32 / 10$ \\
\hline $\begin{array}{l}\text { Good pay (E) } \\
\text { Recognition for a job well } \\
\text { done (E) }\end{array}$ & $6.05 / 7$ & $5.32 / 4$ & $6.17 / 8$ \\
\hline $\begin{array}{l}\text { Joob security, unlikely to } \\
\text { be laid off (E) }\end{array}$ & $3.71 / 2$ & $2.51 / 2$ & $5.81 / 6$ \\
\hline fonefits (E) & $5.22 / 5$ & $8.83 / 9$ & $5.37 / 4$ \\
\hline
\end{tabular}

Note: Mean ranks of 1.00 is most important and 11.00 is least important. 
performed, participation in business decisions, to be with people; have friends at work.

Without exception, each intrinsic attribute was ranked significantly higher for the manager and each extrinsic attribute was presumed to be more important for the workers. This was true even for those firms with high employee involvement. Thus, Eder (1988) concluded that the high technology managers underestimated the importance of intrinsic job attributes and overestimated the importance of extrinsic attributes. Managers' ranking of workers' preferences and rankings for themselves are shown in Table VII.

TABLE VII

U.S. MANAGERS' RANKING OF WORKERS AND THEMSELVES

\begin{tabular}{|l|l|}
\hline \multicolumn{1}{|c|}{ Managers' ranking of workers } & Managers' ranking of themselves \\
\hline Good pay & Good pay \\
\hline Job security & Chance to develop skdlls and abilities \\
\hline Recognition for a job well done & Interesting work \\
\hline Good pension and benefits & Recognition for a job well done \\
\hline
\end{tabular}

Self Reference theory (Kovach 1987) is often used to explain the mismatch between managers and workers job attribute preferences. Managers offer rewards for workers that would motivate them (managers) even though these rewards are not necessarily the ones 
that would motivate their workers. Table VIII summarizes Kovach's (1987) survey results of 1,000 Americans which supported his theory.

TABLE VIII

RANKING OF U.S. EMPLOYEE JOB ATTRIBUTE PREFERENCES

BY THE EMPLOYEES THEMSELVES AND

THEIR SUPERVISORS

\begin{tabular}{|c|c|c|c|}
\hline Job attribute & $\begin{array}{l}\text { Supervisors' } \\
\text { ranking of } \\
\text { employees }\end{array}$ & $\begin{array}{c}\text { Employees } \\
\text { self-ranking }\end{array}$ & $\begin{array}{l}\text { Supervisors' } \\
\text { self-ranking }\end{array}$ \\
\hline Interesting work (I) & 5 & 1 & 1 \\
\hline Full appreciation of work done (I?) & 8 & 2 & 2 \\
\hline Feeling of being in on things (I/E?) & 10 & 3 & 3 \\
\hline Job security $(E)$ & 2 & 4 & 4 \\
\hline Good wages $(E)$ & 1 & 5 & 6 \\
\hline $\begin{array}{l}\text { Promotion/growth in the } \\
\text { organization (E) }\end{array}$ & 3 & 6 & 5 \\
\hline Good working conditions (E) & 4 & 7 & 7 \\
\hline Personal loyalty to employees (E) & 7 & 8 & 8 \\
\hline Tactful discipline (E) & 9 & 9 & 9 \\
\hline $\begin{array}{l}\text { Sympathetic help with personal } \\
\text { problems (E) }\end{array}$ & 6 & 10 & 10 \\
\hline
\end{tabular}


Kovach (1987) pointed out that the absolute ranking of the items is less important than the wide variance between what employees deemed important to their jobs and what their supervisors thought was important to these employees. Note that the employees most frequently cited "interesting work" as their highest rated need. When managers were asked what the employees wanted, they said "good wages." To describe this perceptual difference, Kovach suggested a phenomena called "self reference" -- managers are really describing what would motivate themselves and not necessarily what would motivate their employees. Kovach (1987: 63) concludes that " ... job security matters to people who don't have it ...." He also pointed out that younger workers (those with less apparent job security) rank "Job Security" second and the over 50 years old group (those with more apparent job security) ranked job security sixth further supporting Maslow's contention that unfulfilled needs motivate and fulfilled needs no longer motivate. It should be pointed out that Kovach's work has the same limitation as discussed above for Jurgensen. Eight or nine of Kovach's attributes are extrinsic and therefore has a more limited view of any differences between extrinsic and intrinsic attributes.

Eder (1988) has suggested that one additional possible reason for the mismatch is that managers assume line workers would not aspire to the same wants and desires as the management group. Researchers have rarely asked managers to project what they think their workers prefer in job attributes and then confront management with the workers' actual preference patterns. 


\section{Mismatch of Job Attribute Preferences in Other Countries}

There is very little work in the literature regarding the mismatch of job attribute preferences in countries other than the U.S. Hunt (1992) studied the attitudes of supervisors and workers in three mines in South Africa during rapid and dramatic socio-political and economic changes, including the demise of the laws and practices of apartheid. He was interested in the impact of these changes on worker attitudes and job attribute preferences.

Hunt (1992) gathered questionnaire data followed by in-depth focus group interviews of all participants. He used a random sample of 14 to 15 workers and five supervisors chosen by the plant managers from three mining companies (total sample of 44 workers and 15 supervisors).

The results of Hunt (1992) are summarized in Table IX. "Employee self-ranking" is the job attribute preference as stated by the employee and "Supervisors' ranking of employees" is the supervisor's perception of the employee's ranking.

Hunt (1992) concluded that the low ranking for "Interesting Work" and the high ranking of "Job Security" are probably caused by an attitude that being employed is better than to be unemployed during the dramatic changes occurring in the country, even if the work is very redundant. Hunt (1992) believed that these results were significantly influenced by race issues such as the affect of black versus white supervisors. Thus the study is informative, but not directly applicable to the Polish situation which does not have similar race issues. 
TABLE IX

JOB ATTRIBUTE PREFERENCES FOR EMPLOYEES IN SOUTH AFRICA

\begin{tabular}{|c|c|c|c|}
\hline Job Factor & $\begin{array}{c}\text { Employees } \\
\text { self-ranking }\end{array}$ & Mismatches & $\begin{array}{l}\text { Supervisors' } \\
\text { ranking of } \\
\text { employees }\end{array}$ \\
\hline Good Pay (E) & 2 & & 1 \\
\hline Job Security (E) & 1 & & 2 \\
\hline Loyalty to Employees (E) & 9 & * & 3 \\
\hline Promotion (E) & 5 & & 4 \\
\hline Good Working Conditions (E) & 3 & 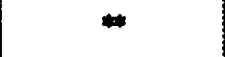 & 5 \\
\hline Help with Personal Problems (E) & 6 & & 6 \\
\hline Interesting Work (I) & 7 & & 7 \\
\hline Full Appreciation of Work (E) & 4 & $*$ & 8 \\
\hline Tactful Discipline (E) & 10 & & 9 \\
\hline Feeling of Being in on Things (I?) & 8 & & 8 \\
\hline
\end{tabular}

Supervisors were relatively in synch with their workers' attitudes with the significant exception of "Conditions," "Feelings," "Loyalty." and "Appreciation." Significance was not calculated statistically, but was defined as two or more ranking positions between workers and their supervisors. Black supervisors had the same gaps 
except for "Loyalty." Hunt explained that black supervisors became part of management and were no longer considered co-workers; thus, black supervisors increased their rating of loyalty to account for their own sense of loss of loyalty.

The results of this study done in 1991 suggested that worker attitudes lag behind real dramatic socio-political change and that U.S. motivational theories do not necessarily work in other countries (or at least in South Africa).

Hunt's (1992) work suffers from a number of problems as it relates to this dissertation: (1) the analysis uses a simple median rank of a relatively small sample, (2) the violence in South Africa could influence these rankings considerably, (3) the study focused on the black/white supervisor issues and not necessarily about the differences in job attribute preferences, and (4) as for the other studies described above, Hunt's list of attributes has eight or nine extrinsic factors, thus perhaps missing significant differences in perceptions.

Harari and Beaty (1989) suggested that in the context of dynamic and turbulent societies (in their case, South Africa), the choice of motivational theory to use is less important than to begin to understand basic motivation. The authors found evidence of "self reference" and other mismatches between attitudes about worker and actual attitude of workers. Their results, including results from previous studies are summarized in Appendix B.

Slocum and Topichak (1972) studied the motivation and satisfaction of Mexican workers using the Porter-need-satisfaction questionnaire. They concluded that culture does affect the hierarchy 
of needs of workers. Slocum and Topichak found significant differences in the satisfaction clusters of security, esteem, autonomy, and self-actualization between Mexican and American workers.

The work by Blinder (1991) with Japanese reinforced the cultural differences. Japanese CEOs are rarely dictators and many top companies are run by consensus. Work is organized into teams, from the executive suite to the factory floor. Important ideas and decisions bubble up from below at least as frequently as they come down from on high. Consultation between labor and management is a pervasive practice in Japanese companies -- much more widespread than in the U.S. Ordinary workers are encouraged to make on-the-spot decisions. Japan and Eastern Europe have the following in common: Japanese workers cooperate with management because their welfare is tied up with that of the company. Large Japanese companies are run for the benefit of their employees rather than their stockholders - providing extensive fringe benefits, job training, job security, narrow pay differentials between executives and ordinary workers (Blinder 1991).

The above data from Japan, Mexico, and South Africa appear to support the conclusion that there are likely differences which are a function of culture and/or nationality. Thus, it is reasonable to expect differences in Polish manager and worker job attribute preferences when compared with other countries.

\section{Mismatch of Job Attribute Preferences in Poland}

There is only a hint of information in the literature describing any differences in perception of job attribute preferences between Polish managers and workers. Kolaja (1960: 129) studied the causes 
of production troubles as perceived by managers and workers. The author of this dissertation accumulated the many reasons into four major categories. The following Table $\mathrm{X}$ ranks major causes for production troubles.

\section{TABLE X}

PRODUCTION PROBLEMS AS PERCEIVED BY WORKERS AND MANAGERS IN POLAND

\begin{tabular}{|l|c|c|}
\hline \multicolumn{1}{|c|}{ Cause } & Management & Workers \\
\hline Machinery or material related & 16 & 78 \\
\hline Outside-of-work items (personal) & 26 & 33 \\
\hline $\begin{array}{l}\text { Organizational issues (not enough } \\
\text { workers) }\end{array}$ & 46 & 54 \\
\hline Motivation due to low pay & 2 & 18 \\
\hline
\end{tabular}

Managers appeared to be out of touch with workers in the area of motivation and affect of machinery or material. There were obvious differences in the area of motivation. Workers and managers disagreed regarding morale due to low pay as a cause of the production troubles (18 to 2). Also noteworthy is the fact that neither group mentioned worker performance as a cause for production troubles. Kolaja offered no explanation for this; however, this omission supports an earlier point that workers and managers are simply "carrying out the plan." These data are discussed here as an example of the low 
level of sophistication of research available regarding management practices in Poland.

Another area of apparent mismatch was the benefit of speeches and slogans. Polish management attempted to persuade and motivate workers through speeches and affirmations regarding patriotic appeal. Although there is no good data on what managers thought about these activities, anecdotal information, recently collected by the author. indicates that managers thought these motivational devices were hokum and often created very negative reactions by workers. Slogans and speeches were continued by management because the communist movement had developed a certain set of institutional behavior supported by the Marx-Leninist theory "Mobilize the masses" as the common duty of the leader (Kolaja 1960).

In the Polish social and economic system, power was concentrated in one center. Lip service was paid to cooperation and the sharing of decisions. This disparity led to demoralizing effects (Kolaja 1960). Thus, there were many organizations that professed to cater to the needs of the workers, but none of them were successful. Statements like "workers rule the factory" were often used by managers, but workers sneered when using the phrase. Kolaja quoted managers saying, "The men are really not interested in management (human resource) issues. They get involved only if their pockets are involved" (Kolaja 1960: 62). This supports the hypothesis that Polish managers will believe extrinsics are key expectations by workers.

Occasionally, the threat of dismissal was used by management as a motivator. But this action was not effective with workers because the 
social philosophy was full employment (Zielinski 1973). This continues to reinforce the idea that there is a mis-perception of workers by managers.

Today, the relationship between workers and managers is changing and in many ways confusing. Old habits die slowly and most workers in state owned companies still see management as the "state" and are not very supportive or understanding. But, workers realize that the environment has changed and their companies and jobs are in jeopardy. Thus, although the workers are not very supportive of management, they know they must cooperate to be successful. The following presents the hypotheses that result from the above literature summary.

\section{Mismatch of Job Attribute Preferences Hypothesis}

It is expected that the management mismatches for the intrinsic job attribute preferences in Poland will be the same as those results reported in the above American and South African studies. Thus, as for U.S. managers, the following hypothesis is offered:

H4: Polish managers' perception of workers' job attribute preferences will tend to underestimate the importance of intrinsic job attribute preferences.

However, there could be a different result for the extrinsic job attributes. Kovach's (1987) "self reference" theory and the large difference in pay levels between U.S. management and workers, reinforcing social status differences, were used to explain the mismatches between American managers' mis-perception of workers' job attribute preferences. But, the social structure within Polish firms are greatly different from those in American firms. American firms 
have a clear distinction between management and labor (workers). Pay levels, perks, job freedom are examples of significant differences between management and workers which create a different social structure and subsequently different motivational patterns.

Polish firms still maintain a social and hierarchical structure similar to that which existed in the pre-economic revolution towards a free-market economy. Managers and workers were and are still considered by many as "equals." This is particularly true for the extrinsic rewards. Polish managers are experiencing the same personal economic shock as workers (Feiwel 1975 and personal conversations with Polish companies, 1992).

In conclusion, although the results for American workers clearly point to a mismatch between managers' perception of workers' extrinsic preferences, the author would expect Polish managers to be much more in touch with their workers extrinsic preferences. Thus, the following hypothesis is presented:

H5: Polish managers will tend to accurately perceive extrinsic job attribute preferences of Polish workers.

\section{THE ORGANIZATIONAL (SUPRA SYSTEM) INFLUENCE} ON THE RESEARCH QUESTION (SYSTEM)

The research questions of this dissertation deal primarily with individuals, organizations, and the interaction of individuals and organizations. This section addresses the effect that the organization and external environment may have on the research questions.

Linstone (1984) introduced the concept of multiple perspectives to ensure that the researcher clearly separated the two 
questions: "What am I looking at?" and "How am I looking at it?" He pointed out that viewing the research question or problem from multiple perspectives often yields new insights, simplifies complex problems, and clarifies conclusions and recommendations. Lendaris (1986) discussed viewing the systems from a vertical perspective (sub systems, systems, and supra systems) and recommended that the researcher (the beholder) move up and down levels of the systems to help define and analyze the problem under investigation. This section deals with Linstone's $O$ - perspective and Lendaris' vertical systems methodology.

To be clear on definitions, the enterprise organization, including management and motivational policies, can be considered the first level above the system in the research question. In addition, the supra system for the organization (system in this view) is the external environment in Poland.

The external environment in Poland is a very powerful force and needs to be considered. This view is particularly important in the current Polish situation because the author believes that if a researcher stopped at the organizational level, he or she might miss a very important analysis and perhaps draw inappropriate conclusions. Specifically, when viewing the highest level to be the organization, a researcher might conclude that different Polish companies, with different leadership and cultural origins, might have different motivational policies and therefore different job attribute preferences of its work force. 
One could expect that the organization would have a significant influence on the motivational policies and ultimately the job attribute preferences of workers. For example, for a Polish high technology firm which has always been privately owned and has had freedom to develop a rich blend of motivational policies, one might expect that workers desiring intrinsic job attributes would be attracted to this firm yielding a work force with a similar pattern to American high technology firms, having a tendency toward intrinsic preferences.

A state owned high technology company, with no potential plans to become private, might have a more closed organizational system and a more extrinsic reward system consistent with the former communist system of motivation, yielding a work force with tendencies toward more extrinsic job attribute preferences.

In these two extremes, one might expect different results from the job attribute preference analysis of managers and workers from different types of Polish enterprises, leading to the following hypothesis:

H6a: There will be significant differences in workers' job attribute preferences among the five Polish high technology enterprises.

However, when viewing this supra system (organization) one level higher, as a system within the environmental supra system, different results might be predicted. Specifically, the external environment in Poland is so dominant that it is possible that there may be no differences in the job attribute preferences in the five companies to be surveyed. The following are the major characteristics 
or policies operating at the external environment which could strongly influence the organizational levels.

First, 50 years of communist control and central-planning cannot be changed overnight. Even though managers have new freedoms in designing motivational policies, new, independent thinking managers must be found and selected. Workers' attitude and expectations need to go through a transformation which in many cases hasn't even begun. The sections on "Poland in Transition" and "Polish Management Practices and Behavior -- A Review" discuss this issue in detail.

Secondly, the Polish government, although professing a "shock treatment" into capitalism, still maintains certain socialist policies which enterprises must obey. For example, every Polish employee in private or state companies receive the same benefits package including pensions, health insurance, etc. In order to keep inflation under control, the Polish government has had a 500\% tax on salary increases since January 1, 1990. These policies severely restrict management's policies and actions in some of the most important reward systems.

Thus, it is possible that the data from workers could be contaminated or biased toward some $O$ - perspective. Linstone (1986: 41) pointed out that normally, key executive's characteristics often become the organization's characteristics. But, " ... when the same characteristic applies to an entire industry, we revert back to the organizational actors." 
Further, Edelman (1967) reported that even though motivation is an individual characteristic, personal behavior may be influenced by the group or organization into which the individual is placed. He suggests that personal work motivation may not be universal or stable, but may depend upon the environment (company, society, culture) in which the person is placed.

The author postulates that the external environment is so strong at this time, and Polish management has made so little progress in the area of motivation, that there will be no real differences among the five types of companies in this research. Thus, if indeed there is significant $O$ - bias (in this case the external environment) in this research, each of the five companies in this study would have the same results regarding worker job attribute preferences. This leads to the following competing hypothesis:

H6b: There will be little or no significant differences in workers' job attribute preferences among the five Polish high technology enterprises.

These competing hypotheses test the effect of the Polish state and external environment in the high technology industry sector. The question to be answered is "does the type of organization affect motivational policies and worker job attribute preferences or are the differences washed out by societal issues?"

It should be pointed out here that the research for this dissertation was designed to minimize contamination or bias from organizational issues $(O)$ and to maximize the data collection from the subjects' personal perspective (P). See the section on Data Collection Procedure for details. 


\section{SUMMARY OF THE HYPOTHESES}

The following is a summary of the hypotheses offered in this dissertation:

H1: The job attribute preferences of Polish workers will tend to be more extrinsic and less intrinsic than those of their American counterparts.

H2: The job attribute preferences of Polish workers who tend to be optimistic about their economic situation will be more intrinsic and less extrinsic than those of Polish workers who tend to be pessimistic.

H3: The job attribute preferences of Polish managers will tend to be more extrinsic and less intrinsic than those of their American counterparts.

H4: Polish managers' perception of workers' job attribute preferences will tend to underestimate the importance of intrinsic job attribute preferences.

H5: Polish managers will tend to accurately perceive extrinsic job attribute preferences of Polish workers.

H6a: There will be significant differences in workers' job attribute preferences among the five Polish high technology enterprises.

H6b: There will be little or no significant differences in workers' job attribute preferences among the five Polish high technology enterprises. 
CHAPTER III

\section{RESEARCH DESIGN}

The purpose of this chapter is to discuss the research design, including the sample, research instruments, data collection procedures, data analysis, and limitations.

\section{SAMPLE}

The population selected for the purposes of carrying out the proposed research study is defined as Polish managers and workers from high technology enterprises with 100 to 500 workers. The high technology industry was chosen to permit a better comparison with U.S. research results (Eder 1988) and to work with firms that have a higher probability of succeeding in the transition to a free market economy.

The sampling frame used in this endeavor is managers and workers from five Polish enterprises in the high technology industry. Five enterprises were chosen to provide a full spectrum of different types of ownership and to permit a more robust test of the hypotheses. The companies are summarized below:

1. A private, never state owned company which develops software products for the banking industry (Firm V).

2. A recently privatized company which designs and produces computer modems (Firm T). 
3. A state owned company, with extensive plans to go private within two months, which manufactures high performance hydraulic pumps for the aircraft and automobile industry Firm P).

4. A state owned company with no plans to become private which designs and produces computer controlled material processing systems (Firm I).

5. A division of a very large state-owned company with no plans to become private which designs and constructs sophisticated, below-the-surface mines (Firm C).

The target sample size is about 15 to 25 managers and 50 to 75 production and technical workers in each firm. Smaller Polish companies were eliminated to ensure a sufficient sample size of managers and supervisors. All managers and a cross section of workers were asked to volunteer for the survey.

\section{RESEARCH INSTRUMENTS}

Four separate instruments were used. Two instruments were used to collect data on job attribute preferences and two other instruments were used to collect organizational data (supra-system).

There was one questionnaire to collect job attribute preferences for managers and another for workers. The worker version has three parts: (1) ranking of personal job attribute preferences, (2) importance ratings using a Likert scale of the same job attribute preferences, and (3) background information. The background questions include demographic information (e.g. as age and gender) and an assessment of the worker's attitude towards their standard of living, job security, confidence in the future, and job satisfaction as an indicator of their personal economic situation. 
The manager version has four parts: (1) ranking of job attribute preferences of workers in their enterprises, (2) ranking of personal job attribute preferences, (3) importance ratings using a Likert scale of the same job attribute preferences, and (4) background information as discussed above. These new research instruments are based on instruments used in Eder (1988) and Eder and Tucker (1982).

Each participant was asked to rank ten job attributes using alternative paired comparison rankings. The job attributes were originally included in a list developed by Kahn (1972) and modified by Eder (1988) and Eder and Tucker (1988). Five of the attributes have been identified by prior research to be extrinsic job attributes and the other five as intrinsic job attributes (Kahn, 1972; Siegfried et al., 1981; Dyer and Parker, 1975).

Copies of the questionnaires in English are included in Appendices $C$ for workers and $D$ for managers. They were translated into Polish (Appendix G) using a Polish-born American citizen with a business education and background. The Polish versions were then reviewed by three Polish managers and one Polish worker who confirmed cultural acceptance, accuracy, and appropriateness. Each firm's questionnaires were color coded to facilitate comparisons across firms.

Two additional questionnaires were designed to collect organizational-level data. Demographic data were collected using the questionnaire in Appendix E. Data on the organization's motivational practices and systems using the questionnaire in Appendix F. The 
organizational variables were chosen to coincide with the job attributes under investigation.

\section{DATA COLLECTION PROCEDURES}

The research was done in Poland during the Fall of 1992. A questionnaire was administered to managers and workers in each of the five selected firms described above. The Presidents of these companies were contacted and provided considerable support for the study. Individual managers and workers were asked to participate by meeting in a conference room and completing the questionnaire. Groups of 15 to 25 individuals were in the meeting which was led by the author with the aid of an interpreter. An instruction sheet, in Polish, was distributed and read by the interpreter. The participants then complete the questionnaire in about 15 minutes. The response rate was $97.8 \%$ ( 7 individuals out of 317 returned their questionnaires blank.

Particular attention was paid in the design of the data collection to ensure anonymity and increase the likelihood of getting the workers' and managers' personal views versus organizational or socially acceptable responses to the questions.

To minimize any contamination or bias from organizational issues $(\mathrm{O})$ and boundary problems, and to maximize the data collection from the subjects' personal perspective (P), the data were collected voluntarily and anonymously. The completed questionnaire was put immediately into a sealed unlabeled envelope and then put into another larger unlabeled sack. The participants were told that neither 
the author nor anyone in the organization would have any way of knowing any individual's answers. The analysis and report would be in a summary form only. Also, the author personally stressed the benefits of giving accurate and personal answers versus rankings which are influenced by the organization or society.

The instruction sheet and questionnaire clearly stated that the personal perspective $(\mathrm{P})$ was required and that there was no risk in giving personal data. For example, the manager's instruction sheet states:

Please assume that the president of your company has appointed you to a special committee to determine what workers in your enterprise want from their work or job experience. To help you with this task you have been provided a list of ten (10) items that are frequently mentioned as important to workers. Please rank the items as you think they would be ranked by workers in your enterprise.

In contrast, if a more organizational $(0)$ perspective or bias was required, the instructions and questions would be stated differently. For example, asking the questions, "What should workers want?" or "What would you want workers to prefer?" would have solicited a more O - perspective. This alternative (collecting data from the organizational perspective) was considered and rejected because this study was interested in real worker and manager motivation and not O-biased or contaminated data.

Organizational-level data on motivational policies and systems was collect in a small group, focus-group forum. The author asked questions in English which the interpreter translated to Polish. In all 
cases, the President or Managing Director was present and provided most of the answers with obvious candor.

\section{DATA ANALYSIS PLAN}

The following describes the data analysis performed on each hypothesis. For clarity, the hypotheses were organized and analyzed in the following way:

- Polish versus American workers and managers (hypotheses 1 and 3)

- Polish managers versus workers (hypotheses 4 and 5)

- Polish pessimists versus optimists (hypothesis 2)

- Polish firm differences (hypothesis 6)

\section{Polish versus American workers and managers (hypotheses 1 and 3)}

The mean rank for each job attribute preference for Polish and American workers and managers was calculated. The data used for Americans were those collected by Eder for high technology companies in Phoenix (Eder 1988). Relative ranks of the Job attribute preferences were determined by ranking the mean ranks.

The statistically significant difference were tested using T-tests and Mann-Whitney - Wilconox Rank Sum W Tests. The Mann-Whitney test provides the most robust analysis of ranked data.

In an attempt to develop a single dimension for the extrinsic or intrinsic job attributes, the creation of a scale using the five extrinsic and intrinsic items was examined using Cronbach's alpha reliability tests. 


\section{Polish managers versus workers (hypotheses 4 and 5 )}

The mean rank for each job attribute preference for Polish workers and managers was calculated. Relative ranks of the job attribute preferences were determined by ranking the mean ranks. Importance ratings were determined by calculating the mean values of the data from the Likert importance scale.

The statistically significant difference in mean ranks and ratings between Polish workers and managers were tested using T-tests and Mann-Whitney - Wilconox Rank Sum W Tests. The Mann-Whitney tests provide the most robust analysis of ranked data.

MANOVA analyses were performed on the clusters of five extrinsic and intrinsic job attributes for Likert ratings. This test was used to determine the overall difference (multivariate) between managers and workers for the cluster of five intrinsic and extrinsic variables.

A correlation matrix was used to determine the existence of any systematic pattern which might exist among the job attribute and the demographic variables. A pattern was determined (workers' extrinsic variables) and subsequently a MANOVA, controlling for the appropriate demographic variables was performed.

\section{Polish pessimists versus optimists (hypothesis 2)}

A single dimension construct for personal economic situation (PES) was developed using the normalized sum of the three individual questions relating to Polish workers' and managers' attitude towards 
their standard of living (SOL), confidence in the future (CIF), and job security (JS). Cronbach's reliabllity alpha was calculated.

The mean rank was calculated for each job attribute preference for Polish workers who tended to be pessimistic and those who tended to be optimistic. Relative ranks of the job attribute preferences were determined by ranking the mean ranks. Importance ratings were determined by calculating the mean values of the data from the Likert importance scale.

The statistically significant difference in mean ranks and ratings between Polish workers who tended to be pessimistic and those who tended to be optimistic were tested using T-tests and Mann-Whitney Wilconox Rank Sum W Tests. The Mann-Whitney tests provide the most robust analysis of ranked data.

MANOVA analyses were performed on the clusters of five extrinsic and intrinsic job attributes for the Likert ratings.

\section{Polish firm differences (hypothesis 6)}

The mean ranks for each job attribute preference for each of the five Polish firms were calculated. Relative ranks of the job attribute preferences were determined by ranking the mean ranks. Importance ratings were determined by calculating the mean values of the data from the Likert importance scale.

MANOVA and One-way ANOVA analyses were performed on the clusters of five extrinsic and intrinsic job attributes for Likert ratings for workers from the five firms. 


\section{LIMITATIONS}

Questionnaire responses are self-reports about how people believe or perceive a situation and may not be the same as how people actually behave or think. Socially desirable responding, or the tendency for a respondent to report invalid responses in an effort to present himself or herself in a favorable light, is often suggested as a major bias in self-report questionnaires. So, too is "impression management" (the conscious presentation of a false front), and "self deception" (the unconscious tendency to see oneself in a favorable light). Spector (1987) concluded that socially desirable contamination need not be of much concern for most self-report research. Moorman and Podsakoff (1992) did a more rigorous study with roughly the same conclusion. Zerbe and Paulhus (1987) and other researchers disagree. In fact, responses are likely to be more idealistic than the behavioral responses. There is little reason, however, to expect this bias to systematically affect workers or managers differently according to their hierarchical level or their gender.

This research is not a causal study or experiment. It is more exploratory and descriptive to verify assumptions and recommend further research. Items such as maturation, learning, history and mortality are not a relevant in this study. Instrumentation and selection issues need to be examined.

The same instrument was used at all five enterprises and the same questions were asked of each respondent. Three of the firms received the same instructions from the author and were translated 
into Polish. Two other firms completed the questionnaire when the author was not present and received the instructions from a delegate. It is possible that the different way of describing the questions and the survey could have biased the answers in an unpredictable way. There was no obvious observed differences among these two firms' answers.

The respondents were basically self-selected. Top management announced to the workers and managers that this research was being done and asked for volunteers. The author was told that almost everyone that was asked did volunteer. It is possible that the sample is biased towards the more assertive or self-confident workers and managers. It is also possible that the workers felt some kind of pressure to participate and therefore attempted to give answers that they expected management wanted to hear.

It is possible that the more pessimistic workers volunteered in order to find a way to voice their opinion about their poor situation. Thus, the sample might be more pessimistic than the population. The U.S. or Western-based theories of motivation and the gaps between managers' and workers' perceptions of workers' job attribute preferences may not be applicable outside the American culture and capitalistic environment. Hofstede's (1980) work supports the importance of culture in explaining national differences and Budde, Child, Francis, Kieser, and Burgleman (1982) found that culture modified the impact of capitalism. Hunt (1992: 12) stated that " ... each nation needs to gather its own data and not rely on U. S. or other countries' theories based on domestic data ... ." Furthermore, Hunt (1992:12) advised "The choice of theories and methods must take the 
local culture into consideration; thus U.S. motivational theories are not likely to apply abroad where different changes are occurring ... ." The theories which do exist for Poland are not applicable because they are based on the now defunct Marxist-Leninist philosophy of work and the social system.

Hunt (1992) also suggested that worker attitudes change during rapid or major social, political, and economic change in the environment. "Perhaps this means that even the data in this study is obsolete as South Africans are in the midst of change to black majority rule as this article goes to press. So, another round of data must be gathered soon" (Hunt 1992: 21). Thus this study may already be obsolete. Data need to be collected and analyzed frequently during the rapid changes in Poland in order to assess the changes and confirm the conclusions.

One must be careful to generalize the results of this work to other cultures. Considerable work has been done which suggests that culture has an effect on motivation and perceptions. Also, no country or society has ever gone through a transition exactly the same as Poland's.

The study is limited to five Polish firms. Although the five firms were carefully selected to ensure the broadest cross section of high technology firms, the sample could be bigger or more scientific. 


\section{CHAPTER IV}

\section{ANALYSIS OF RESEARCH FINDINGS}

The purpose of this chapter is to discuss the results of the statistical analysis of the data. General characteristics of the sample are first discussed to provide a context within which the hypotheses are to be addressed. Then, the individual statistical test results regarding each of the six hypotheses are discussed in the following order:

Results: Poland versus America (hypotheses 1 and 3)

Results: Polish managers versus workers (hypotheses 4 and 5)

Results: Polish pessimists versus optimists (hypothesis 2)

Results: Polish firm differences (hypothesis 6)

Results: A summary (all hypotheses)

For clarity and simplicity, the following abbreviations will be used throughout this chapter:

Results: Seeing the results of my (or their) work Interesting: Interesting work

Growing: Job in a growing field

Develop: Chance to develop my (or their) skills and abilities Say: Considerable "say" in how my (or their) job is performed Security: Job security; unlikely to lose my (or their) job Good pay: Good pay

Recognition: Recognition for a job well done 
Benefits: Good pension and other benefits

Friends: To be with people $\&$ have my (or their) friends at work

\section{CHARACTERISTICS OF THE SAMPLE}

\section{Firm demographics}

Data were collected from five firms with different forms of ownership and legal structures. Appendix $\mathrm{H}$ presents a summary description of each of the five firms. The five high technology firms used in this sample provide a rich spectrum of different type of firms ranging from small private firms that have never been state owned through large state firms with no plans to privatize.

There is a wide variance in age of the firms ( 5 to 31 years), number of employees (37 to 483 ), and sales revenue (\$0.5 to 10.0 million). One of the firms, firm $\mathrm{C}$, is actually a wholly owned division of a very large company with 42,000 workers. Although the firms all produce high technology products, there is a wide range of specific product (heavy industry to software to computer hardware). -

\section{Sample demographics}

The following five Tables and Figures describe the sample used in this research. Table XI presents the research sample by firm including the number of respondents, and the respondents' mean tenure and age. There is a wide variance in both the mean job tenure

(from 1.8 to 17.2 years) and the mean age (from 30.3 to 44.9 years).

Table XII presents the sample size, the mean job tenure, and the mean age for each job type and for males and females. 
TABLE XI

RESEARCH SAMPLE: RESPONDENTS BY FIRM

\begin{tabular}{|l|c|c|c|c|c|c|}
\hline & Firm V & Firm T & Firm P & Firm I & Firm C & $\begin{array}{c}\text { All } \\
\text { firms }\end{array}$ \\
\hline Number of respondents & 31 & 47 & 84 & 90 & 65 & 317 \\
\hline Mean job tenure (years) & 1.8 & 12.4 & 17.2 & 15.3 & 16.8 & 14.3 \\
\hline Mean age (years) & 30.3 & 38.8 & 41.6 & 42.1 & 44.9 & 40.9 \\
\hline
\end{tabular}

Respondents from a wide range of jobs are included in the sample -- top managers include executives and director-level positions; managers include foremen, supervisors and functional managers in departments such as marketing and manufacturing; white collar workers include engineering professionals, marketing and office staff; blue collar workers include mostly production personnel. Persons in very low level jobs such as "sweepers" were excluded to be consistent with the American sample.

As expected, workers are younger and have less tenure than managers. Females represent about one-third of the sample and are younger and have less tenure than males.

Figures 5 and 6 below present the frequency distribution of tenure and age of the total sample of Polish workers and managers. The tenure distribution is roughly flat from 2 to 30 years with a mean of 14.3 years. The low numbers in the 11 through 18 years could be due to the emigration from Poland during Martial Law in the early 1980s. The age distribution has roughly a normal bell-shape with a 
TABLE XII

RESEARCH SAMPLE: RESPONDENTS BY JOB TYPE AND GENDER

\begin{tabular}{|c|c|c|c|}
\hline & $\begin{array}{c}\text { Number of } \\
\text { responses }\end{array}$ & $\begin{array}{c}\text { Mean job } \\
\text { tenure (years) }\end{array}$ & $\begin{array}{c}\text { Mean age } \\
\text { (years) }\end{array}$ \\
\hline Top Managers & 27 & 18.8 & 48.5 \\
\hline Managers & 46 & 17.2 & 43.6 \\
\hline All Managers & 73 & 18.0 & 45.4 \\
\hline White Collar Workers & 176 & 12.9 & 40.2 \\
\hline Blue Collar Workers & 68 & 14.4 & 38.1 \\
\hline All Workers & 244 & 13.3 & 39.6 \\
\hline Females & 107 & 13.4 & 39.8 \\
\hline Males & 210 & 14.8 & 41.5 \\
\hline
\end{tabular}

mean of 40.9 years. The large spike at 45 years could be caused by a Polish baby boom occurring in 1947, right after World War II.

A single dimension construct for personal economic situation (PES) was developed using the normalized sum of the three individual questions relating to Polish workers' and managers' attitude towards their standard of living (SOL), confidence in the future (CIF), and job

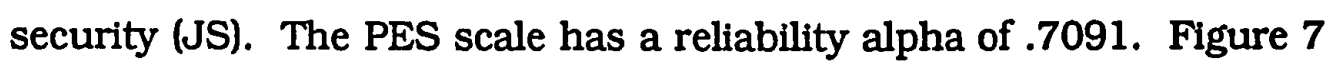


75

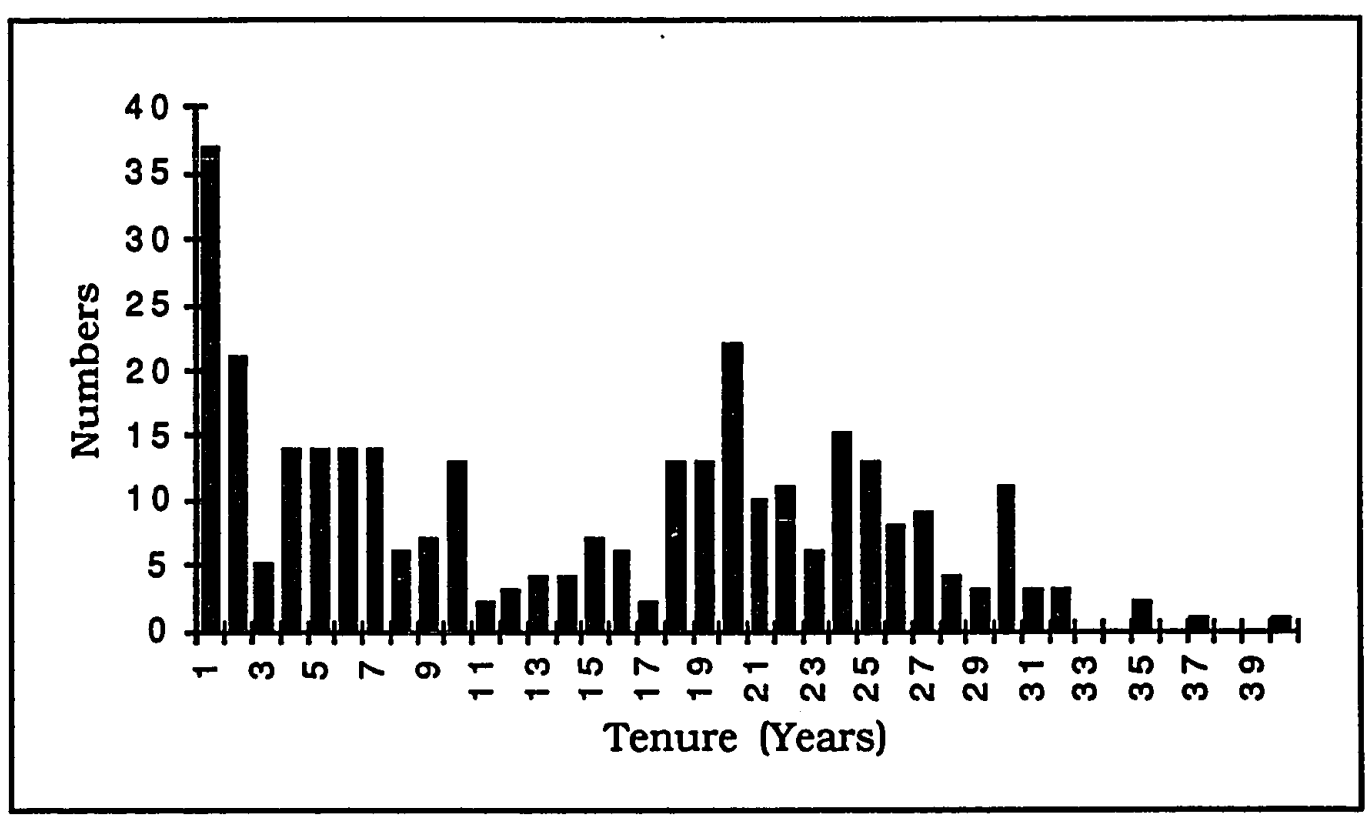

Figure 5. Frequency distribution for tenure (years).

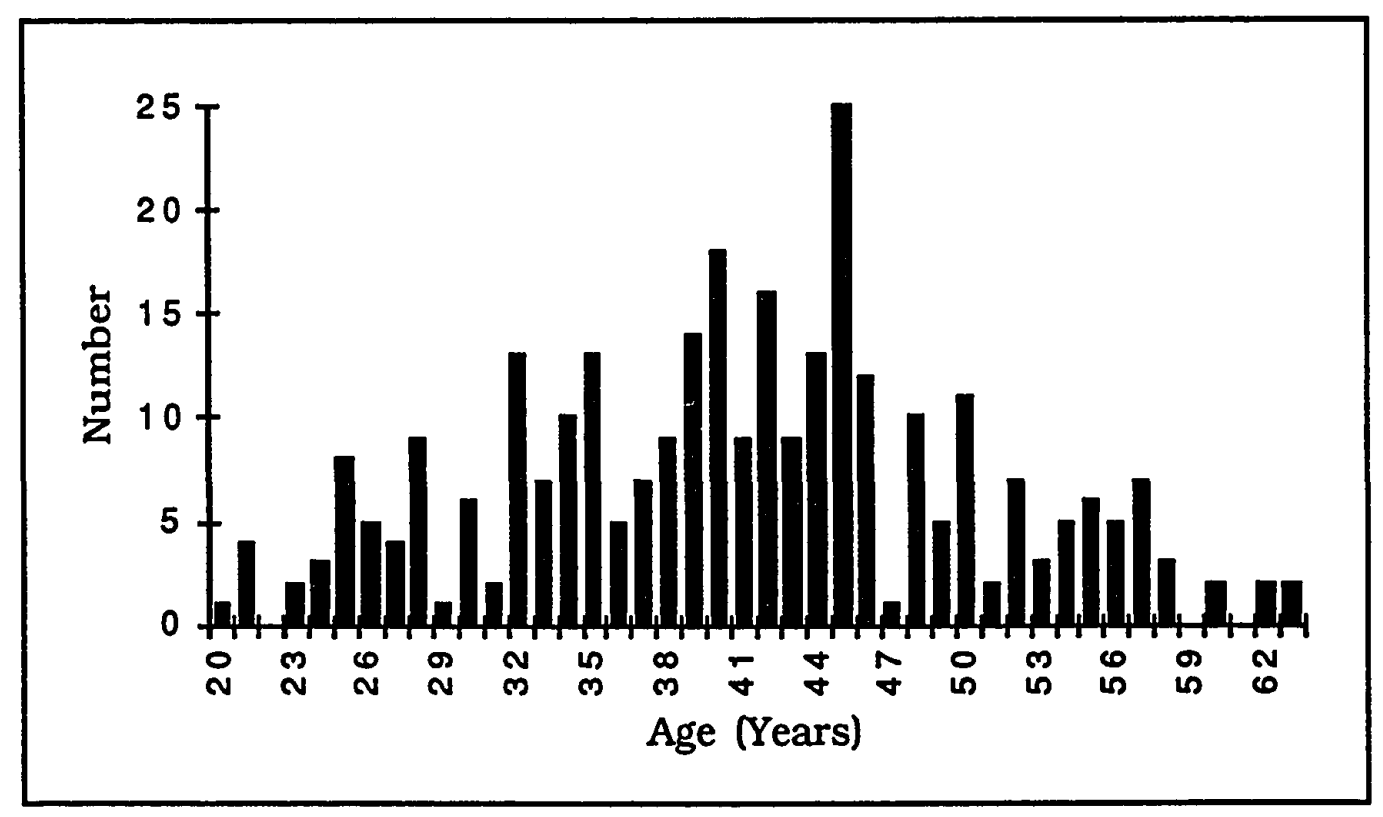

Figure 6. Frequency distribution for age (years). 
presents the frequency distribution of PES (the specific values are presented in Appendix I). The shape of the distribution is roughly normal, but skewed toward pessimism, as expected in Poland at this time. Ratings from 1.33 to 2.67 , inclusively, were considered to be "optimistic" and ratings from 3.67 to 5.00 . inclusively, was considered to be "pessimistic."

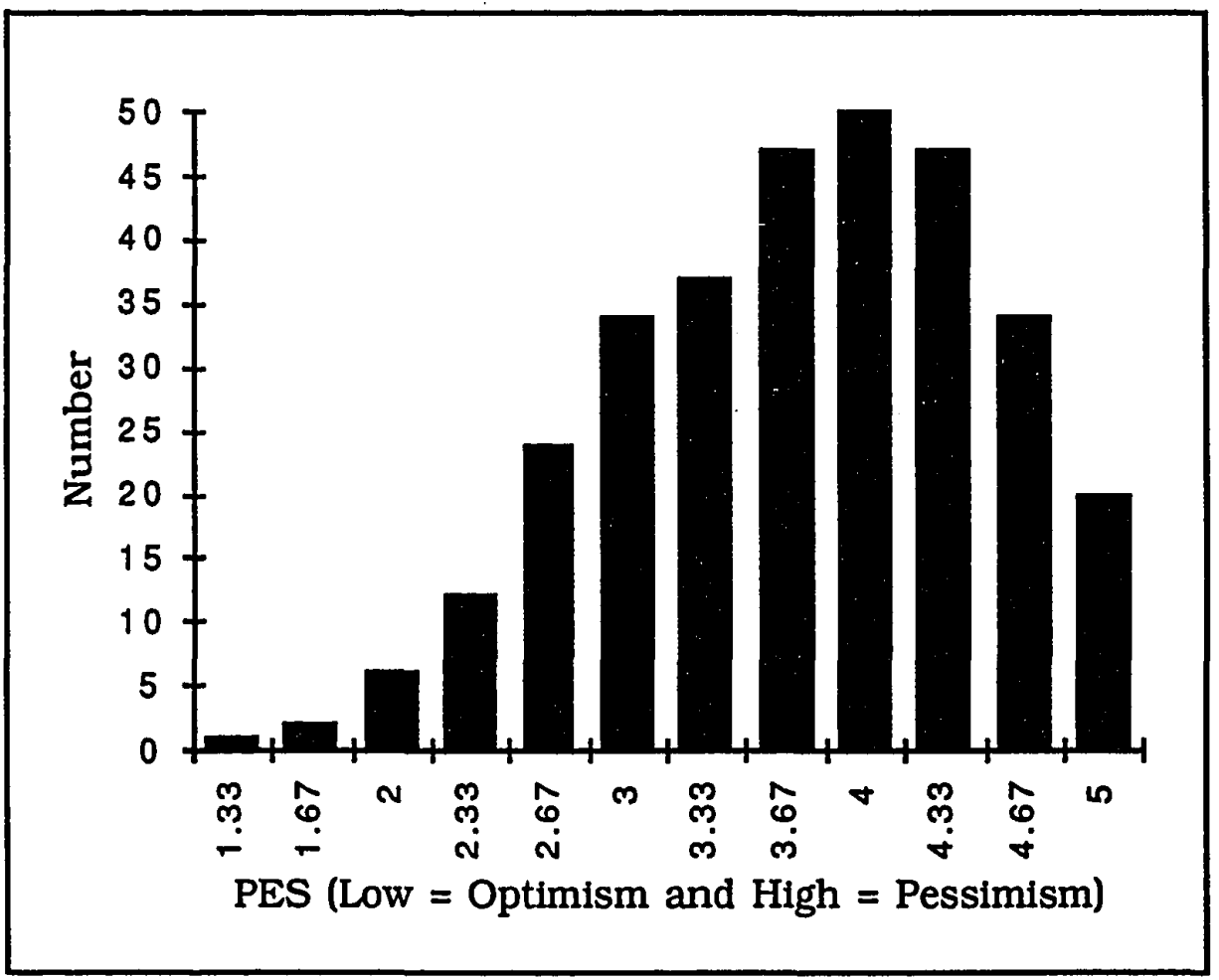

Figure 7. Frequency distribution of Personal Economic Situation (PES). Lower values of PES means more optimistic and higher values of PES means more pessimistic.

Directors and senior managers from all five firms enthusiastically supported the research activities and cooperated in arranging a nonthreatening environment for respondents who volunteered. Although 
the percentage of individuals who refused to participate was not determined, conversations with managers indicate that most workers and managers were very happy to participate. Only seven of 317 questionnaires were returned blanked.

Overall, the sample appears to be consistent with the goals of the dissertation and appears to match the profile of what might be expected from the Polish high technology work force, including type of job, gender, age, tenure, PES, and firm ownership.

\section{Correlation Matrices}

Tables XIII through XVI present the correlation coefficients for the job attribute preference Likert ratings and key demographic variables for all respondents.

Tables XIII and XIV present the correlation matrices for the intrinsic and extrinsic job attribute preferences for workers, respectively. Correlations greater than .16 are significant at the .01 level for a sample size of 233.

The statistically significant correlations between the job attribute preferences for workers and the demographic variables appear to indicate the following. For the intrinsic job attributes, there is only one statistically significant correlation. The more experienced (longer tenured) and older worker rates Develop lower than the less experienced and younger worker. Apparently, older and more experienced workers believe that developing their skills and abilities is less important. For the most part, age, tenure, gender, and PES do not systematically effect a workers' intrinsic job attribute preferences. 
There are more statistically significant correlations for the extrinsic job attributes. As might be expected, the more pessimistic workers rank Security, Good pay, and Benefits higher than optimistic workers. In addition, the more experienced and older workers tend to rate Security and Benefits higher than the less experienced and younger workers. Thus suggests the need to control for these demographic effects when analyzing extrinsic job attribute preferences. This was done for hypotheses 4 and 5 and is reported below.

The older and more tenured workers are significantly more pessimistic than the younger and less tenured. The older workers have a long history of socialist control and have a much shorter time horizon to view the probability of success in the transition to a free market economy. Thus, it would be expected that these workers would feel more pessimistic.

Tables XV and XVI present the correlation matrices for the intrinsic and extrinsic job attributes for managers, respectively. Correlations greater than .28 are significant at the .01 level for a sample size of 71 .

There are no significant correlations between the managers' intrinsic job attribute preferences and the demographic variables. For the extrinsic variables, there are two significant correlations. Older managers rate Security higher than younger managers and more experienced and older managers rate Benefits higher than less experienced and younger managers. 
TABLE XIII

CORRELATION MATRIX: INTRINSIC JOB ATTRIBUTES AND MAJOR DEMOGRAPHIC VARIABLES FOR POLISH WORKERS

\begin{tabular}{|c|c|c|c|c|c|c|c|c|c|}
\hline$n=233$ & Results & Intercsting & Growing & Develop & Say & Gender & Tenure & PES & Age \\
\hline Results & 1.00 & & & & & & & & \\
\hline Interesting & .04 & 1.00 & & & & & & & \\
\hline Growing & .12 & .10 & 1.00 & & & & & & \\
\hline Develop & .31 & .34 & .11 & 1.00 & & & & & \\
\hline Say & .20 & .24 & .08 & .08 & 1.00 & & & & \\
\hline Gender & -.04 & .05 & -.04 & .11 & -.03 & 1.00 & & & \\
\hline Tenure & -.02 & -.10 & -.03 & -.28 & -.05 & -.03 & 1.00 & & \\
\hline PES & -.16 & -.09 & -.11 & -.15 & -.11 & -.18 & .41 & 1.00 & \\
\hline Abe & .08 & -.05 & -.05 & -.25 & -.03 & -.02 & .70 & .37 & 1.00 \\
\hline
\end{tabular}

Note: $r>.16$ significant at .01 level for $\mathrm{n}=233$. 
TABLE XIV

CORRELATION MATRIX: EXTRINSIC JOB ATTRIBUTES AND MAJOR DEMOGRAPHIC VARIABLES FOR POLISH WORKERS

\begin{tabular}{|c||c|c|c|c|c|c|c|c|c|}
\hline $\mathrm{n}=233$ & Securty & Good pay & Recognition & Benefits & Frlends & Gender & Tenure & PES & Age \\
\hline \hline Securtty & 1.00 & & & & & & & & \\
\hline Good pay & .37 & 1.00 & & & & & & & \\
\hline Recognition & -.06 & .05 & 1.00 & & & & & & \\
\hline Benefits & .39 & .31 & .24 & 1.00 & & & & & \\
\hline Friends & .04 & .13 & .27 & .25 & 1.00 & & & & \\
\hline Gender & -.11 & -.11 & -.18 & -.08 & -.18 & 1.00 & & & \\
\hline Tenure & .23 & .05 & -.01 & .26 & -.08 & -.03 & 1.00 & & \\
\hline PES & .25 & .21 & .04 & .26 & -.04 & -.18 & .41 & 1.00 & \\
\hline Age & .10 & .01 & .03 & .17 & -.11 & -.02 & .70 & .37 & 1.00 \\
\hline
\end{tabular}

Note: $r>.16$ significant at .01 level for $n=233$. 
TABLE XV

CORRELATION MATRIX: INTRINSIC JOB ATTRIBUTES AND MAJOR DEMOGRAPHIC VARIABLES FOR POLISH MANAGERS

\begin{tabular}{|c||c|c|c|c|c|c|c|c|c|}
\hline $\mathrm{n}=71$ & Results & Interesting & Growing & Develop & Say & Gender & Tenure & PES & Afe \\
\hline \hline Results & 1.00 & & & & & & & & \\
\hline Interesting & .01 & 1.00 & & & & & & & \\
\hline Growing & .15 & .26 & 1.00 & & & & & & \\
\hline Develop & .42 & .25 & .27 & 1.00 & & & & & \\
\hline Say & .33 & .14 & .32 & .38 & 1.00 & & & & \\
\hline Gender & -.22 &. .05 & .04 & -.06 & -.08 & 1.00 & & & \\
\hline Tenure & -.09 & .05 & .17 & -.03 & -.15 & .26 & 1.00 & & \\
\hline PES &. .08 & .25 & .09 & .11 & -.13 &. .09 & .26 & & \\
\hline Age & -.13 & .02 & .12 & -.13 & -.33 & .26 & .74 & .18 & \\
\hline
\end{tabular}

Note: $r>.28$ significant at .01 level for $n=71$. 
TABLE XVI

CORRELATION MATRIX: EXTRINSIC JOB ATTRIBUTES AND MAJOR DEMOGRAPHIC VARIABLES FOR POLISH MANAGERS

\begin{tabular}{|c||c|c|c|c|c|c|c|c|c|}
\hline$n=71$ & Securty & Good pay & Recognition & Benefits & Friends & Gender & Tenure & PES & Age \\
\hline \hline Security & 1.00 & & & & & & & & \\
\hline Good pay & .07 & 1.00 & & & & & & & \\
\hline Recognition & -.13 & .00 & 1.00 & & & & & & \\
\hline Benefits & .27 & .28 & .03 & 1.00 & & & & \\
\hline Friends & .15 & .05 & .23 & .10 & 1.00 & & & \\
\hline Gender & -.01 & -.23 & -.14 & -.02 & .15 & 1.00 & & \\
\hline Tenure & .23 & -.11 & .07 & .36 & -.10 & .26 & 1.00 & & \\
\hline PES & .12 & .08 & .09 & .09 & -.08 & -.09 & .26 & 1.00 & \\
\hline Age & .37 & -.16 & -.14 & .28 & -.16 & .26 & .74 & .18 & 1.00 \\
\hline
\end{tabular}

Note: $r>.28$ significant at .01 level for $n=71$. 


\section{RESULTS: POLAND VERSUS AMERICA}

(HYPOTHESES 1 AND 3)

The first and third hypotheses involve differences between Polish and American workers (hypothesis 1), and Polish and American Managers (hypothesis 3). Both hypotheses involve extrinsic and intrinsic job attributes and for clarity, the analysis for each hypothesis will be presented in two parts (a) extrinsic and (b) intrinsic job attributes. The data for American workers are from Eder (1988). The following section presents the relevant results for the subsequent hypotheses, Hla, H1b, H3a, and H3b.

\section{Hypothesis 1 (a and b)}

The job attribute preferences of Polish workers will tend to be more extrinsic and less intrinsic than those of their American counterparts.

There were two expectations regarding hypothesis 1: (a) Polish workers would rank the extrinsic job attributes higher than American workers; and (b) Polish workers would rank the intrinsic job attributes lower than American workers.

The results of a Mann-Whitney - Wilconox Rank Sum W Test for the extrinsic job attributes (hypothesis la) are summarized in Table XVII. The Polish workers ranked two extrinsic job attributes (Recognition and Friends) higher than their American counterparts as predicted and the others (Security, Benefits, and Good pay) lower than their American counterparts. All five differences were found to be statistically significant at $\mathrm{p}<.05$. 
The results of T-tests for significance in the difference of the mean ranks are summarized in Table XVII. All mean rank differences, except for Good pay, were statistically significant at $p<.01$.

TABLE XVII

HYPOTHESIS 1A - EXTRINSIC JOB ATTRIBUTES FOR WORKERS:

MANN-WHITNEY AND T-TESTS RESULTS

\begin{tabular}{|l|c|c|c|c|c|c|}
\hline $\begin{array}{c}\text { Extrinsic } \\
\text { Job }\end{array}$ & $\begin{array}{c}\text { Mean } \\
\text { Rank } \\
\text { Polish } \\
\text { Workers }\end{array}$ & $\begin{array}{c}\text { Mean } \\
\text { Rank } \\
\text { U.S. } \\
\text { Workers }\end{array}$ & $\begin{array}{c}\text { p value } \\
\text { Mann- } \\
\text { Whitney }\end{array}$ & $\begin{array}{c}\text { p value } \\
\text { T-Tests }\end{array}$ & $\begin{array}{c}\text { Relative } \\
\text { Rank } \\
\text { Polish } \\
\text { Workers }\end{array}$ & $\begin{array}{c}\text { Relative } \\
\text { Rank } \\
\text { U.S. } \\
\text { Workers }\end{array}$ \\
\hline Securtty & 5.00 & 3.57 & .00 & .00 & 5 & 2 \\
\hline Good pay & 2.68 & 2.56 & .04 & .51 & 1 & 1 \\
\hline Recognition & 4.95 & 6.23 & .00 & .00 & 4 & 8 \\
\hline Benefits & 7.48 & 5.02 & .00 & .00 & 10 & 4 \\
\hline Friends & 7.20 & 8.26 & .00 & .00 & 8 & 10 \\
\hline
\end{tabular}

Note: The lower the value of the rank (nominal or mean), the more important the item. A nominal or mean rank of 1 is most important and a nominal or mean rank of 10 is least important.

The profiles displayed in Figure 8 show the relative ranks of Polish and American workers' extrinsic job attributes. The Polish workers ranked two extrinsic job attributes (Recognition and Friends) higher than their American counterparts as predicted and two others lower (Security and Benefits). Good pay was ranked the same by both Polish and American workers. 


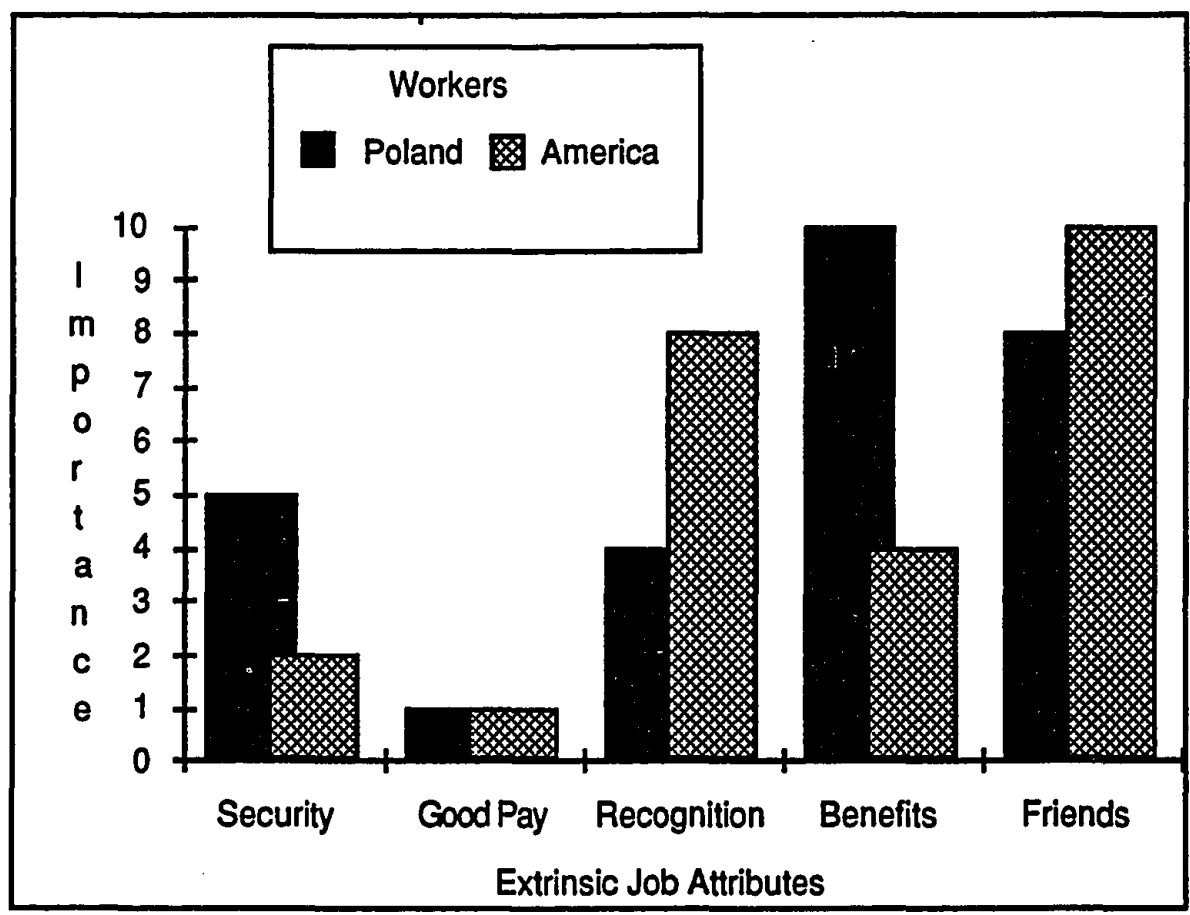

Figure 8. Profile of extrinsic job attributes for Polish and American workers. Importance ranks of 1 means more important and 10 means less important.

Summarizing the results for hypothesis 1a, only two of the five extrinsic attributes (Recognition and Friends) are ranked higher by Polish workers versus American workers. Three extrinsics (Security, Good pay, and Benefits) were actually ranked lower by Polish workers than their American counterparts. Thus, hypothesis la must be rejected. Demographics appear to fail to explain this result.

The results of a Mann-Whitney - Wilconox Rank Sum W Test for the intrinsic job attributes (hypothesis $1 b$ ) are summarized in Table XVIII. The Polish workers ranked two intrinsic job attributes (Growing and Develop) lower than their American counterparts as predicted and the others (Results, Interesting, and Say) higher than 
their American counterparts. All five differences were found to be statistically significant at $\mathrm{p}<.01$.

The results of $\mathrm{T}$-tests for significance in the difference of the mean ranks are also summarized in Table XVIII. All mean rank differences, except for Develop, were statistically significant at $p<.01$.

\section{TABLE XVIII}

HYPOTHESIS 1B - INTRINSIC JOB ATTRIBUTES FOR WORKERS: MANN-WHITNEY AND T-TESTS RESULTS

\begin{tabular}{|l|c|c|c|c|c|c|}
\hline $\begin{array}{c}\text { Intrinsic } \\
\text { Job } \\
\text { Attribute }\end{array}$ & $\begin{array}{c}\text { Mean } \\
\text { Rank } \\
\text { Polish } \\
\text { Workers }\end{array}$ & $\begin{array}{c}\text { Mean } \\
\text { Rank } \\
\text { U.S. } \\
\text { Workers }\end{array}$ & $\begin{array}{c}\text { p value } \\
\text { Mann- } \\
\text { Whitney }\end{array}$ & $\begin{array}{c}\text { p value } \\
\text { T-Tests }\end{array}$ & $\begin{array}{c}\text { Relative } \\
\text { Rank } \\
\text { Polish } \\
\text { Workers }\end{array}$ & $\begin{array}{c}\text { Relative } \\
\text { Rank } \\
\text { U.S. } \\
\text { Workers }\end{array}$ \\
\hline Results & 4.08 & 6.01 & .00 & .00 & 3 & 7 \\
\hline Interesting & 4.07 & 4.92 & .00 & .00 & 2 & 3 \\
\hline Growing & 7.33 & 5.84 & .00 & .00 & 9 & 6 \\
\hline Develop & 5.47 & 5.17 & .00 & .48 & 6 & 5 \\
\hline Say & 6.76 & 7.99 & .00 & .00 & 7 & 9 \\
\hline
\end{tabular}

Note: The lower the value of the rank (nominal or mean), the more important the item. A nominal or mean rank of 1 is most important and a nominal or mean rank of 10 is least important.

The profiles displayed in Figure 9 show the relative ranks of Polish and American workers' intrinsic job attributes. The Polish workers ranked two job attributes (Growing and Develop) lower than their American counterparts as predicted and the others higher (Results, Interesting, and Say). 


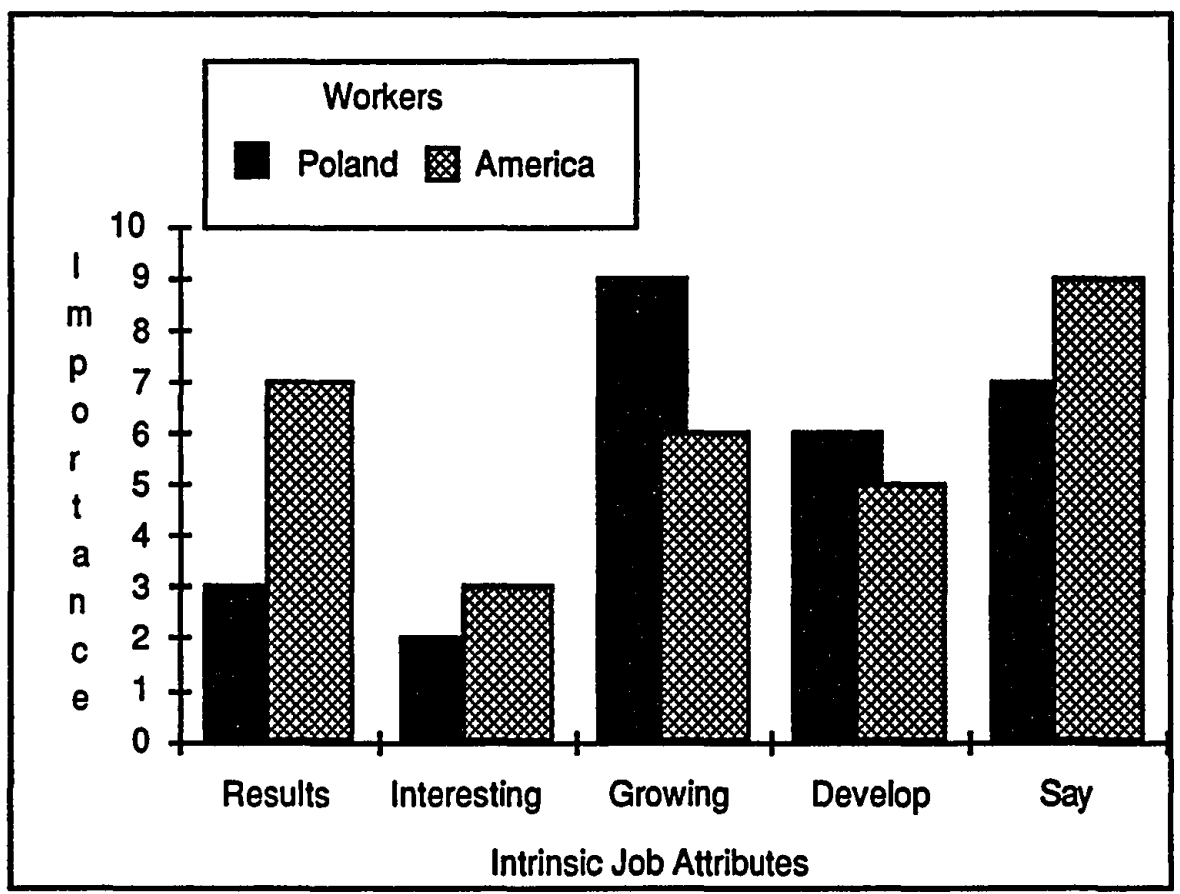

Figure 9. Profile of intrinsic job attributes for Polish and American workers. Importance ranks of 1 means more important and 10 means less important.

Summarizing the results for hypothesis $1 \mathrm{~b}$, only two of the five intrinsic attributes (Growing and Develop) are ranked relatively lower by Polish workers versus American workers. Three intrinsics (Results, Interesting, and Say) were actually ranked higher by Polish workers than their American counterparts. Thus, hypothesis lb must be rejected. Demographics appear to fail to explain this result.

Overall for hypothesis 1 ( $a$ and $b$ ), only five of the ten job attributes are statistically significant in the predicted direction. Four of the ten are statistically significant in the opposite direction. On first examination, hypothesis 1 is not supported. 
Hypothesis 3 (a and $b$ )

The job attribute preferences of Polish managers will tend to be more extrinsic and less intrinsic than those of their American counterparts.

There were two expectations regarding hypothesis 3: (a) Polish managers would rank the extrinsic job attributes higher than American managers; and (b) Polish managers would rank the intrinsic job attributes lower than American managers. The data for American workers are from Eder (1988).

The results of a Mann-Whitney - Wilconox Rank Sum W Test for the extrinsic job attributes (hypothesis 3a) are summarized in Table XIX. The Polish managers ranked three extrinsic job attributes (Security, Good pay, and Friends) higher than their American counterparts as predicted and the others (Recognition and Benefits) lower than their American counterparts. The differences for Good pay, Benefits and Friends were found to be statistically significant at $p$ $<.05$, while Security and Recognition were not significant.

The results of $T$-tests for significance in the difference of the mean ranks are also summarized in Table XIX. The differences for Good pay, Benefits and Friends were found to be statistically significant at $\mathrm{p}<.01$.

The profiles displayed in Figure 10 show the relative ranks of Polish and American managers' extrinsic job attributes. The Polish managers ranked one extrinsic job attribute (Friends) higher than their American counterparts as predicted and two others lower (Recognition and Benefits). Good pay and Security were ranked the same by both Polish and American managers. 
TABLE XIX

HYPOTHESIS 3A - EXTRINSIC JOB ATTRIBUTES FOR MANAGERS: MANN-WHITNEY AND T-TESTS RESULTS

\begin{tabular}{|l|c|c|c|c|c|c|}
\hline $\begin{array}{c}\text { Extrinsic } \\
\text { Job } \\
\text { Attribute }\end{array}$ & $\begin{array}{c}\text { Mean } \\
\text { Rank } \\
\text { Polish } \\
\text { Managers }\end{array}$ & $\begin{array}{c}\text { Mean } \\
\text { Rank } \\
\text { U.S. } \\
\text { Managers }\end{array}$ & $\begin{array}{c}\text { p value } \\
\text { Mann- } \\
\text { Whitney }\end{array}$ & $\begin{array}{c}\text { p value } \\
\text { T-Tests }\end{array}$ & $\begin{array}{c}\text { Relative } \\
\text { Rank } \\
\text { Polish } \\
\text { Managers }\end{array}$ & $\begin{array}{c}\text { Relative } \\
\text { Rank } \\
\text { U.S. } \\
\text { Managers }\end{array}$ \\
\hline Security & 5.36 & 5.39 & .89 & .95 & 6 & 6 \\
\hline Good pay & 2.89 & 4.10 & .03 & .00 & 1 & 1 \\
\hline Recognition & 5.16 & 4.98 & .61 & .69 & 5 & 4 \\
\hline Benefits & 8.01 & 5.73 & .00 & .00 & 10 & 9 \\
\hline Friends & 7.84 & 8.90 & .00 & .01 & 9 & 10 \\
\hline
\end{tabular}

Note: The lower the value of the rank (nominal or mean), the more important the item. A nominal or mean rank of 1 is most important and a nominal or mean rank of 10 is least important.

Summarizing the results for hypothesis $3 a$, three of the five extrinsic attributes (Security, Good pay, and Friends) are ranked relatively higher by Polish managers versus American managers. Two extrinsics (Recognition and Benefits) were actually ranked lower by Polish managers than their American counterparts. Thus, hypothesis 3a must be rejected.

The results of a Mann-Whitney - Wilconox Rank Sum W Test for the intrinsic job attributes (hypothesis $3 \mathrm{~b}$ ) are summarized in Table XX. The Polish managers ranked three intrinsic job attributes (Growing, Develop, and Say) lower than their American counterparts 


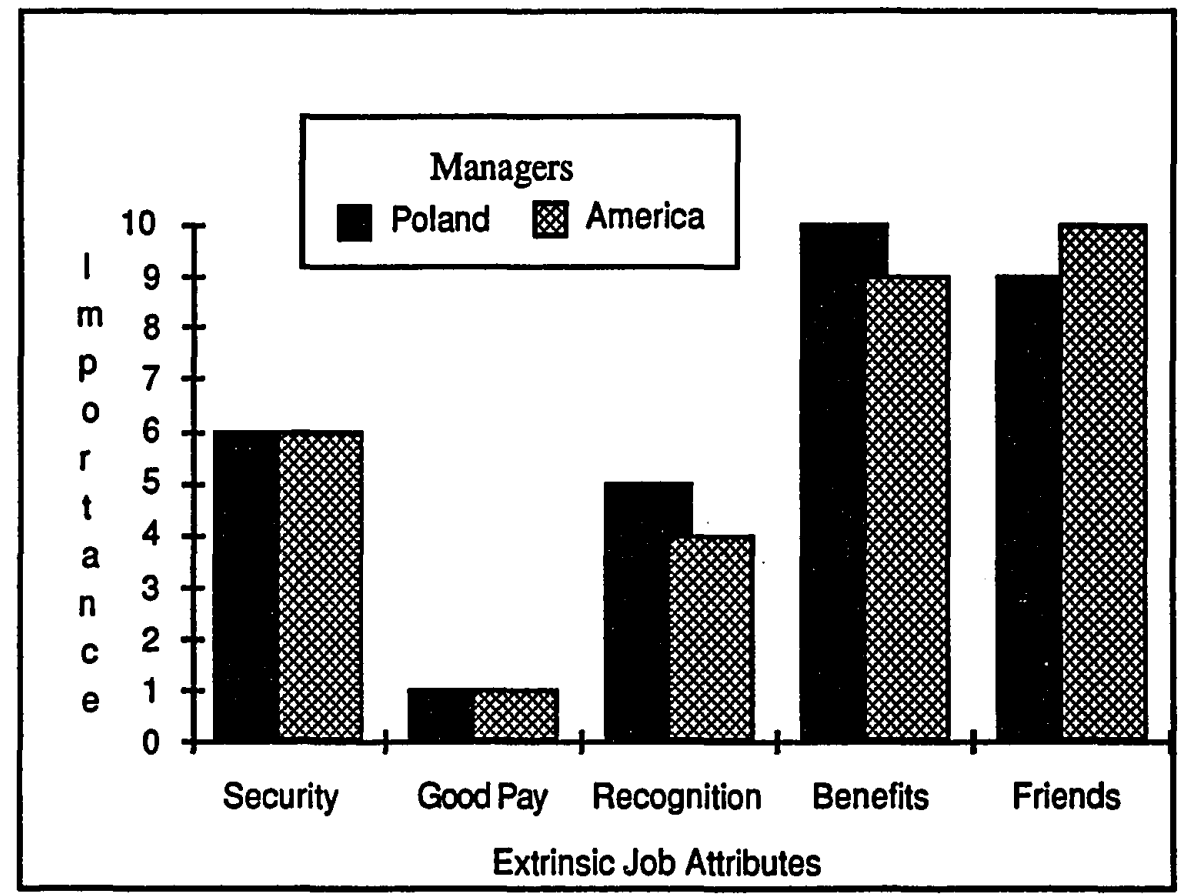

Figure 10. Profile of extrinsic job attributes for Polish and American managers. Importance ranks of 1 means more important and 10 means less important.

as predicted and the others (Results and Interesting) higher than their American counterparts. All differences, except for Develop, were found to be statistically significant at $p<.01$.

The results of T-tests for significance in the difference of the mean ranks are also summarized in Table XX. All mean rank differences, except for Develop, were statistically significant at $p<.05$.

The profiles displayed in Figure 11 show the relative ranks of Polish and American managers for the intrinsic job attributes. The Polish managers ranked two job attributes (Growing and Develop) lower than their American counterparts as predicted and the others 
TABLE XX

HYPOTHESIS 3B - INTRINSIC JOB ATTRIBUTES FOR MANAGERS: MANN-WHITNEY AND T-TESTS RESULTS

\begin{tabular}{|l|c|c|c|c|c|c|}
\hline $\begin{array}{c}\text { Intrinslc } \\
\text { Job } \\
\text { Attribute }\end{array}$ & $\begin{array}{c}\text { Mean } \\
\text { Rank } \\
\text { Polish } \\
\text { Managers }\end{array}$ & $\begin{array}{c}\text { Mean } \\
\text { Rank } \\
\text { U.S. } \\
\text { Managers }\end{array}$ & $\begin{array}{c}\text { p value } \\
\text { Mann- } \\
\text { Whitney }\end{array}$ & $\begin{array}{c}\text { p value } \\
\text { T-Tests }\end{array}$ & $\begin{array}{c}\text { Relative } \\
\text { Rank } \\
\text { Polish } \\
\text { Managers }\end{array}$ & $\begin{array}{c}\text { Relative } \\
\text { Rank } \\
\text { U.S. } \\
\text { Managers }\end{array}$ \\
\hline Results & 3.23 & 5.14 & .00 & .00 & 2 & 5 \\
\hline Interesting & 3.51 & 4.88 & .00 & .01 & 3 & 3 \\
\hline Growing & 7.25 & 5.44 & .00 & .00 & 8 & 7 \\
\hline Develop & 4.64 & 4.44 & .60 & .66 & 4 & 2 \\
\hline Say & 7.00 & 5.71 & .01 & .01 & 7 & 8 \\
\hline
\end{tabular}

Note: The lower the value of the rank (nominal or mean), the more important the item. A nominal or mean rank of 1 is most important and a nominal or mean rank of 10 is least important.

higher (Results and Say). Interesting was ranked the same by Polish and American managers.

Summarizing the results for hypothesis $3 b$, three of the five intrinsic attributes (Growing, Develop and Say) are ranked lower by Polish managers versus American managers. Two intrinsics (Results and Interesting) were actually ranked higher by Polish managers than their American counterparts. Thus, hypothesis $3 \mathrm{~b}$ must be rejected.

Overall for hypothesis 3 ( $a$ and $b$ ), six of the ten job attributes are in the predicted direction (four statistically significant). Four of the ten are in the opposite direction (three statistically significant). On first examination, hypothesis 3 is not supported. 


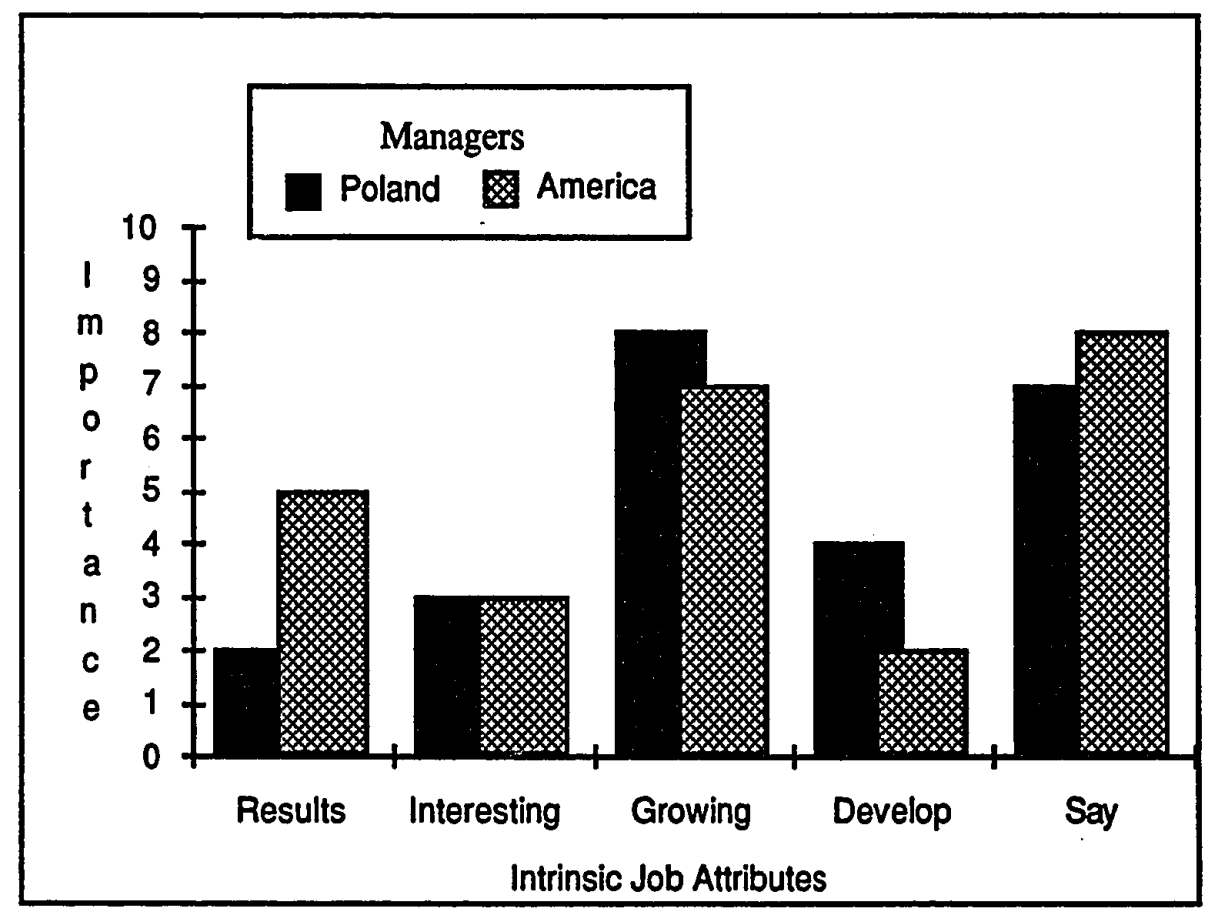

Figure 11. Profile of intrinsic job attributes for Polish and American managers. Importance ranks of 1 means more important and 10 means less important.

\section{RESULTS: POLISH MANAGERS VERSUS WORKERS}

(HYPOTHESES 4 AND 5)

Hypotheses 4 and 5 involve differences between Polish managers' perception of workers' job attribute preferences and workers' stated preferences. Hypothesis 4 involves the intrinsic job attributes and hypothesis 5 involves extrinsic job attributes. The following section presents the relevant results. 


\section{Hypothesis 4}

Polish managers' perception of workers' job attribute preferences will tend to underestimate the importance of intrinsic job attribute preferences.

It was expected that Polish managers would rank the workers' intrinsic job attributes preferences lower than Polish workers would rank their own job attributes.

The results of a Mann-Whitney - Wilconox Rank Sum W Test for the intrinsic job attributes are summarized in Table XXI. The Polish managers ranked the workers' three intrinsic job attributes (Results, Interesting, and Say) lower than the workers' ranked their own preferences as predicted and the other two (Growing and Develop) higher than the Polish workers. However, none of the differences were found to be statistically significant at $p<.05$.

The results of $T$-tests for significance in the difference of the mean ranks are also summarized in Table XXI. And again, none of the differences were found to be statistically significant at $p<.05$.

The profiles displayed in Figure 12 show the relative ranks of the Polish workers' intrinsic job attribute preferences by managers and workers. The Polish managers ranked only one of the workers' attributes (Say) lower than workers ranked their own preferences as predicted and one (Growing) higher than workers. Three of the workers' intrinsic job attributes (Results, Interesting, and Develop) were ranked the same by managers and workers.

Likert importance ratings, which were not available in the American sample, are available for the Polish sample; thus further analysis can be accomplished. The results of a MANOVA and T-Test 
TABLE XXI

HYPOTHESIS 4 - MANAGERS' PERCEPTION OF WORKERS AND WORKERS' INTRINSIC JOB ATTRIBUTE PREFERENCES: MANNWHITNEY AND T-TESTS RESULTS

\begin{tabular}{||l|c|c|c|c|c|c|}
\hline \multicolumn{1}{|c|}{$\begin{array}{c}\text { Intrinsic } \\
\text { Job } \\
\text { Attribute }\end{array}$} & $\begin{array}{c}\text { Mean } \\
\text { Rank } \\
\text { Polish } \\
\text { Workers } \\
\text { by } \\
\text { Workers } \\
\mathrm{n}=209\end{array}$ & $\begin{array}{c}\text { Mean } \\
\text { Rank } \\
\text { Polish } \\
\text { Workers } \\
\text { by } \\
\text { Managers } \\
\text { n=67 }\end{array}$ & $\begin{array}{c}\text { p value } \\
\text { Mann- } \\
\text { Whitney }\end{array}$ & $\begin{array}{c}\text { p value } \\
\text { T-Tests }\end{array}$ & $\begin{array}{c}\text { Relative } \\
\text { Rank } \\
\text { Polish } \\
\text { Workers - } \\
\text { by } \\
\text { Workers }\end{array}$ & $\begin{array}{c}\text { Relative } \\
\text { Rank } \\
\text { Polish } \\
\text { Workers - } \\
\text { by } \\
\text { Managers }\end{array}$ \\
\hline Results & 4.075 & 4.15 & .94 & .82 & 3 & 3 \\
\hline Interesting & 4.071 & 4.11 & .65 & .90 & 2 & 2 \\
\hline Growing & 7.33 & 6.71 & .05 & .08 & 9 & 7 \\
\hline Develop & 5.47 & 5.43 & .95 & .92 & 6 & 6 \\
\hline Say & 6.76 & 7.22 & .21 & .14 & 7 & 8 \\
\hline
\end{tabular}

Note: The lower the value of the rank (nominal or mean), the more important the item. A nominal or mean rank of 1 is most important and a nominal or mean rank of 10 is least important.

for the intrinsic job attributes using the Likert importance ratings are summarized in Table XXII. The Polish managers rated two of the workers attributes (Interesting and Say) as less important than workers rated their own preferences as predicted and the other three intrinsics (Results, Growing, and Develop) more important. None of the differences in the mean ratings are statistically significant. These results generally support those found using the rank data reported above. 


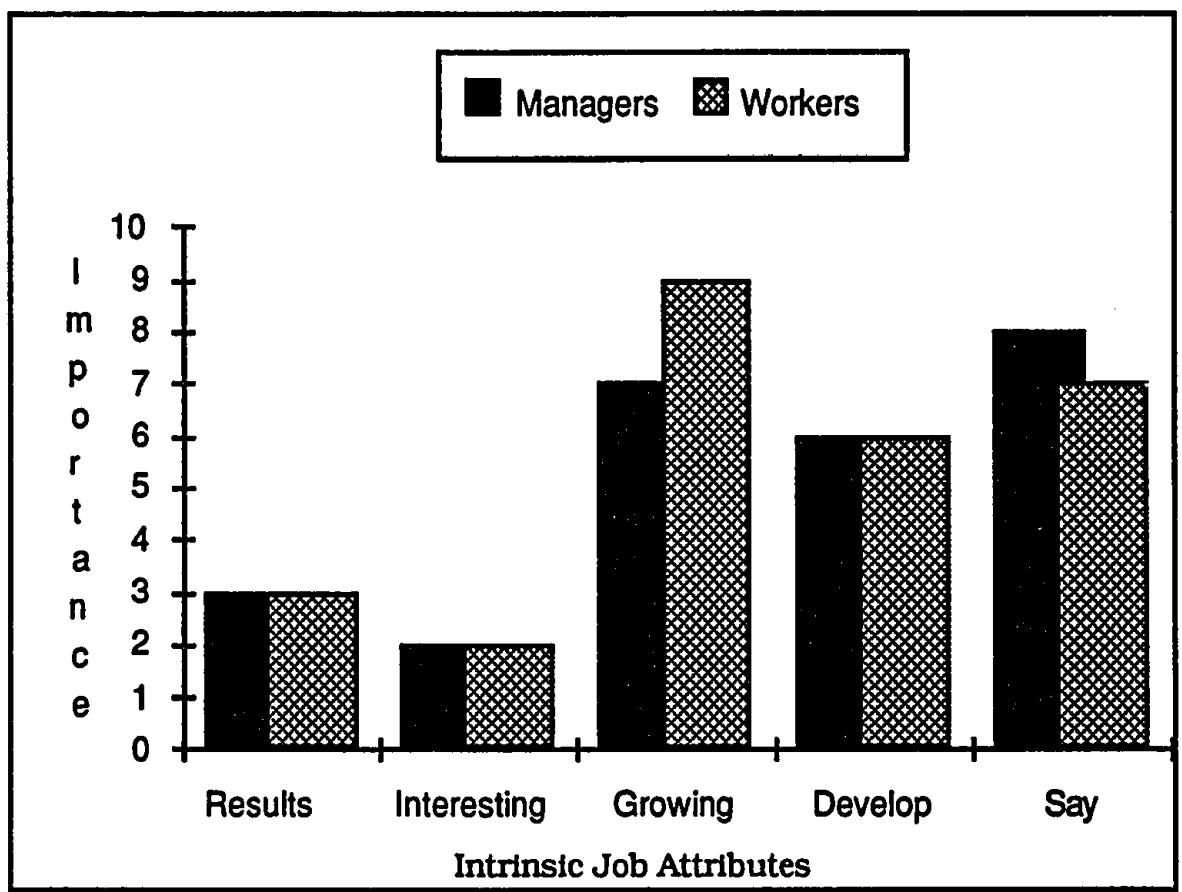

Figure 12. Profile of Polish workers' intrinsic job attributes preferences by workers and managers. Importance ranks of 1 means more important and 10 means less important.

The results of a one-way ANOVA were substantially the same as the above. None of the differences in the attributes were found to be significant.

Overall for hypothesis 4 , two or perhaps three of the five intrinsic attributes are in the predicted direction. The other intrinsics are in the opposite direction. None of the attributes were found to be statistically significant. On first examination, hypothesis 4 is not supported.

\section{Hypothesis 5}

Polish managers will tend to accurately perceive extrinsic job attribute preferences of Polish workers. 
TABLE XXII

\section{HYPOTHESIS 4 - MANAGERS' PERCEPTION OF WORKERS AND WORKERS' INTRINSIC JOB ATTRIBUTE PREFERENCES: LIKERT RATING RESULTS}

\begin{tabular}{|l|c|c|c|c|c|}
\hline $\begin{array}{c}\text { Intrinsic } \\
\text { Job } \\
\text { Attribute }\end{array}$ & $\begin{array}{c}\text { Mean } \\
\text { Rank } \\
\text { Polish } \\
\text { Workers - } \\
\text { by } \\
\text { Workers } \\
\text { n=209 }\end{array}$ & $\begin{array}{c}\text { Mean } \\
\text { Rank } \\
\text { Polish } \\
\text { Workers } \\
\text { by } \\
\text { Managers } \\
\text { n=67 }\end{array}$ & $\begin{array}{c}\text { p value } \\
\text { T-Tests }\end{array}$ & F-value & p-value \\
\hline Results & 3.41 & 3.53 & .34 & 0.94 & .33 \\
\hline Interesting & 3.49 & 3.31 & .16 & 2.40 & .12 \\
\hline Growing & 2.61 & 2.62 & .94 & 0.00 & .99 \\
\hline Develop & 3.32 & 3.33 & .95 & 0.00 & .98 \\
\hline Say & 3.08 & 2.90 & .19 & 1.71 & .19 \\
\hline Multivariate & & &. & 1.06 & .38 \\
\hline
\end{tabular}

Note: The higher the value of the rating , the more important the item. A mean rating of 5 is most important and a mean rating of 1 is least important.

The results of a Mann-Whitney - Wilconox Rank Sum W Test for the extrinsic job attributes are summarized in Table XXIII. The Polish managers ranked three of the workers' extrinsic job attribute preferences (Security, Good pay, and Recognition) higher than workers rated their own preferences and the other two (Growing and Develop) lower. But, only one attribute (Friends) was found to be 
statistically significant at $p<.05$. Managers ranked this lower than workers did.

TABLE XXIII

HYPOTHESIS 5 - MANAGERS' PERCEPTION OF WORKERS AND WORKERS' EXTRINSIC JOB ATTRIBUTE PREFERENCES: MANN-WHITNEY AND T-TESTS RESULTS

\begin{tabular}{|l|c|c|c|c|c|c|}
\hline $\begin{array}{l}\text { Extrinsic } \\
\text { Job } \\
\text { Attribute }\end{array}$ & $\begin{array}{c}\text { Mean } \\
\text { Rank } \\
\text { Polish } \\
\text { Workers - } \\
\text { by } \\
\text { Workers } \\
\mathrm{n}=209\end{array}$ & $\begin{array}{c}\text { Mean } \\
\text { Rank } \\
\text { Polish } \\
\text { Workers } \\
\text { by } \\
\text { Managers } \\
\text { n=67 }\end{array}$ & $\begin{array}{c}\text { p value } \\
\text { Mann- } \\
\text { Whitney }\end{array}$ & $\begin{array}{c}\text { p value } \\
\text { T-Tests }\end{array}$ & $\begin{array}{c}\text { Relative } \\
\text { Rank } \\
\text { Polish } \\
\text { Workers - } \\
\text { by } \\
\text { Workers }\end{array}$ & $\begin{array}{c}\text { Relative } \\
\text { Rank } \\
\text { Polish } \\
\text { Workers - } \\
\text { by } \\
\text { Managers }\end{array}$ \\
\hline Security & 5.00 & 4.30 & .08 & .06 & 5 & 4 \\
\hline Good pay & 2.67 & 2.27 & .07 & .08 & 1 & 1 \\
\hline Recognition & 4.95 & 4.84 & .61 & .71 & 4 & 5 \\
\hline Benefits & 7.48 & 7.84 & .22 & .25 & 10 & 9 \\
\hline Friends & 7.20 & 8.03 & .00 & .01 & 8 & 10 \\
\hline
\end{tabular}

Note: The lower the value of the rank (nominal or mean), the more important the item. A nominal or mean rank of 1 is most important and a nominal or mean rank of 10 is least important.

The results of T-tests for significance in the difference of the mean ranks are also summarized in Table XXIII. Only one attribute (Friends) was found to be statistically significant at $\mathrm{p}<.05$.

The profiles displayed in Figure 13 show that the relative ranks of the Polish workers' extrinsic job attributes by managers and workers are quite similar as predicted. The maximum difference for 
any individual attribute is one rank position. One workers' attribute (Good pay) is identically ranked by managers and workers. Managers ranked two of the workers' attributes (Security and Benefits) one position higher than workers and two others (Recognition and Friends) one position lower than workers.

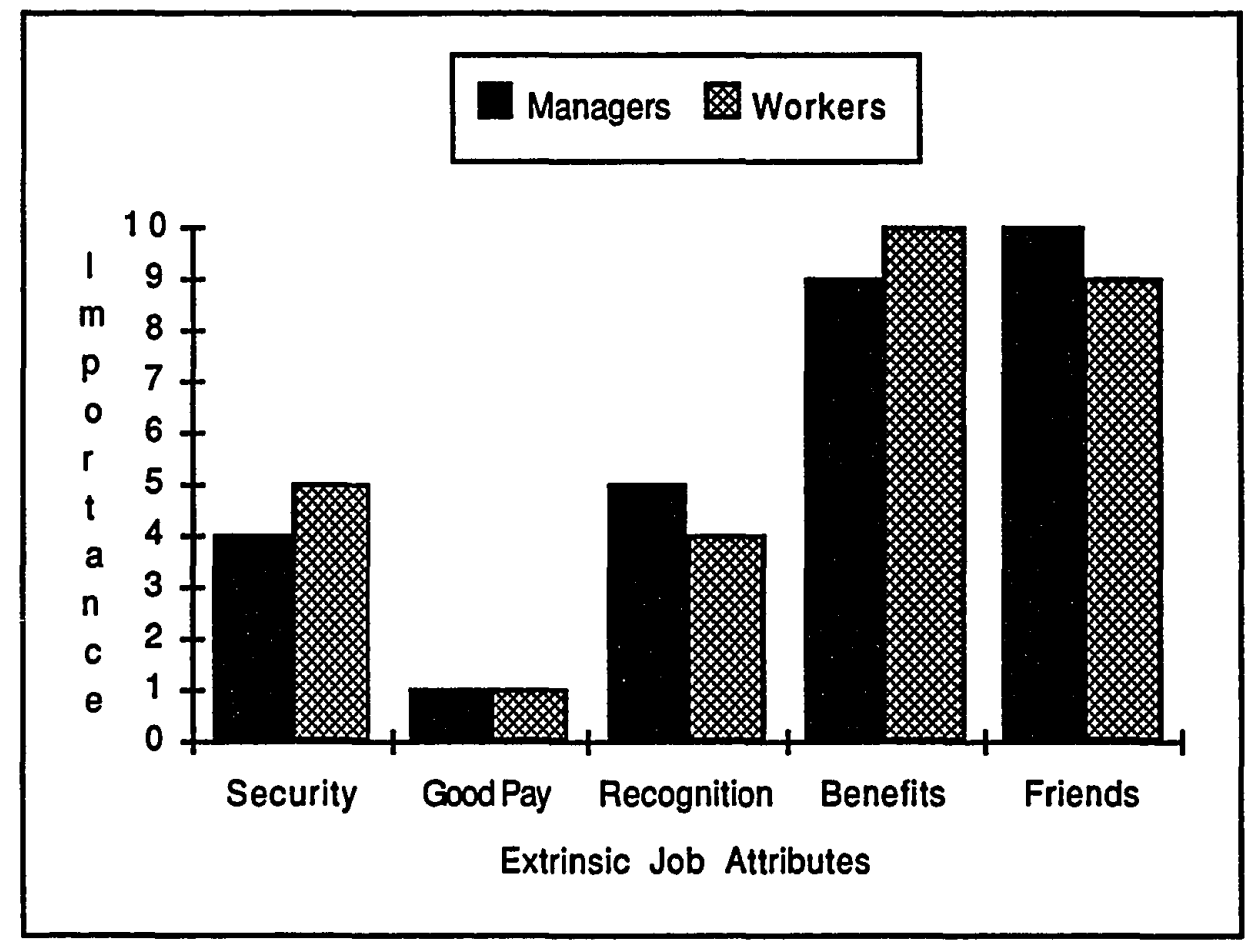

Figure 13. Profile of Polish workers' extrinsic job attribute preferences by workers and managers. Importance ranks of 1 means more important and 10 means less important.

Likert importance ratings for the extrinsics, which were not available in the American sample, are available for the Polish sample; thus further analysis can be accomplished. The results of a MANOVA and T-Tests for the extrinsic job attributes using the Likert importance ratings are summarized in Table XXIV. The Polish 
managers rated three of the workers' job attributes (Good pay, Benefits, and Friends) as less important than workers rated their own preferences and the others (Security and Recognition) more important. The differences in the mean ratings for only two attributes (Benefits and Friends) are statistically significant at $p<.05$. These results generally support those found using the rank data.

The results of a one-way ANOVA were substantially the same as above, with the exception that Benefits was found to be not significant.

TABLE XXIV

\section{HYPOTHESIS 5 - MANAGERS' PERCEPTION OF WORKERS AND \\ WORKERS' EXTRINSIC JOB ATTRIBUTE PREFERENCES: LIKERT RATING RESULTS}

\begin{tabular}{|l|c|c|c|c|c|}
\hline $\begin{array}{c}\text { Extrinsic } \\
\text { Job } \\
\text { Attribute }\end{array}$ & $\begin{array}{c}\text { Mean } \\
\text { Rank } \\
\text { Polish } \\
\text { Workers- } \\
\text { by } \\
\text { Workers } \\
\text { n=209 }\end{array}$ & $\begin{array}{c}\text { Mean } \\
\text { Rank } \\
\text { Polish } \\
\text { Workers - } \\
\text { by } \\
\text { n=67 }\end{array}$ & $\begin{array}{c}\text { p value } \\
\text { T-Tests }\end{array}$ & F-value & p-value \\
\hline Security & 3.44 & 3.49 & .75 & 0.10 & .75 \\
\hline Good pay & 4.19 & 4.16 & .82 & 0.00 & .97 \\
\hline Recognition & 3.62 & 3.67 & .68 & 0.23 & .64 \\
\hline Benefits & 2.983 & 2.56 & .01 & 8.19 & .01 \\
\hline Friends & 2.979 & 2.40 & .00 & 16.16 & .00 \\
\hline Multivariate & & & & 5.37 & .00 \\
\hline
\end{tabular}

Note: The higher the value of the rating, the more important the item. A mean rating of 5 is most important and a mean rating of 1 is least important. 
The correlation table and discussion at the beginning of this chapter indicated that age, tenure, and PES strongly affected Security and Benefits, suggesting the need to factor out these demographic variables.

The results of a MANOVA controlling for age, PES, and tenure were generally consistent with the above results. The multivariate results are about the same as above $(F=3.75, p=.00)$. Two attributes (Security: $F=7.03, p=.00$; and Benefits: $F=10.80, p=.00$ ) were found to be significant, while Friends, which was significant above, was found to be not significant when controlling for age, PES and tenure. Apparently, the difference in Friends is related to the key demographic variables, rather than managers' mis-perception.

The overall results appear to support hypothesis 5. Two attributes (Friends and Benefits, or Security and Benefits) were found to be statistically different between Polish and American managers. On first examination, hypothesis 5 appears to be supported.

\section{RESULTS: POLISH PESSIMISTS VERSUS OPTIMISTS}

(HYPOTHESIS 2)

Hypothesis 2 ( $a$ and $b$ )

The job attribute preferences of Polish workers who tend to be optimistic about their economic situation will be more intrinsic and less extrinsic than those of Polish workers who tend to be pessimistic.

There were two expectations regarding hypothesis 2: (a) Polish workers who tend to be pessimistic would rank the extrinsic job attributes higher than those who tend to be optimistic; and (b) Polish workers who tend to be pessimistic would rank the intrinsic job 
attributes lower than those who tend to be optimistic. For simplicity in this section, workers who tend to be optimistic (PES ratings from 1.33 to 2.67 ) will be called optimists and those who tend to be pessimistic (PES ratings from 3.67 to 5.00 ) will be called pessimists.

The results of a Mann-Whitney - Wilcoxon Rank Sum W Test for the extrinsic job attributes (hypothesis 2a) are summarized in Table XXV. The pessimists ranked four attributes (Security, Good pay, Recognition, and Benefits) higher than optimists as predicted. One attribute (Friends) is in the opposite direction. The mean rank differences for three attributes (Security, Good pay, and Benefits) are significant at $\mathrm{p}<.05$.

\section{TABLE XXV}

HYPOTHESIS 2A - EXTRINSIC ATTRIBUTES FOR PESSIMISTS AND OPTIMISTS: MANN-WHITNEY AND T-TESTS RESULTS

\begin{tabular}{|l|c|c|c|c|c|c|}
\hline $\begin{array}{c}\text { Extrinsic } \\
\text { Job } \\
\text { Attribute }\end{array}$ & $\begin{array}{c}\text { Mean } \\
\text { Rank } \\
\text { Pessimists } \\
\mathrm{n}=170\end{array}$ & $\begin{array}{c}\text { Mean } \\
\text { Rank } \\
\text { Optimists } \\
\mathrm{n}=21\end{array}$ & $\begin{array}{c}\text { p value } \\
\text { Mann- } \\
\text { Whitney }\end{array}$ & $\begin{array}{c}\text { p value } \\
\text { T-Tests }\end{array}$ & $\begin{array}{c}\text { Relative } \\
\text { Rank } \\
\text { Polish } \\
\text { Pessimists }\end{array}$ & $\begin{array}{c}\text { Relative } \\
\text { Rank } \\
\text { Polish } \\
\text { Optimists }\end{array}$ \\
\hline Security & 4.52 & 6.48 & .01 & .00 & 4 & 8 \\
\hline Good pay & 2.50 & 4.10 & .00 & .00 & 1 & 3 \\
\hline Recognition & 4.74 & 5.19 & .28 & .40 & 5 & 5 \\
\hline Benefits & 7.12 & 8.90 & .00 & .00 & 8 & 10 \\
\hline Friends & 7.36 & 6.29 & .06 & .03 & 9 & 7 \\
\hline
\end{tabular}

Note: The lower the value of the rank (nominal or mean), the more important the item. A nominal or mean rank of 1 is most important and a nominal or mean rank of 10 is least important. 
The results of T-tests for significance in the difference of the mean ranks are also summarized in Table XXV. All of the attributes, except one (Recognition), were found to be statistically significant at $p$ $<.05$.

The profiles displayed in Figure 14 show that the relative ranks for pessimists for three extrinsics (Security, Good pay, and Benefits) are higher than the optimists' ranks as predicted. For one extrinsic job attribute (Recognition) the relative ranks are the same for both pessimists and optimists. For the remaining job attribute (Friends) the Polish pessimists' relative rank is lower than the optimists.

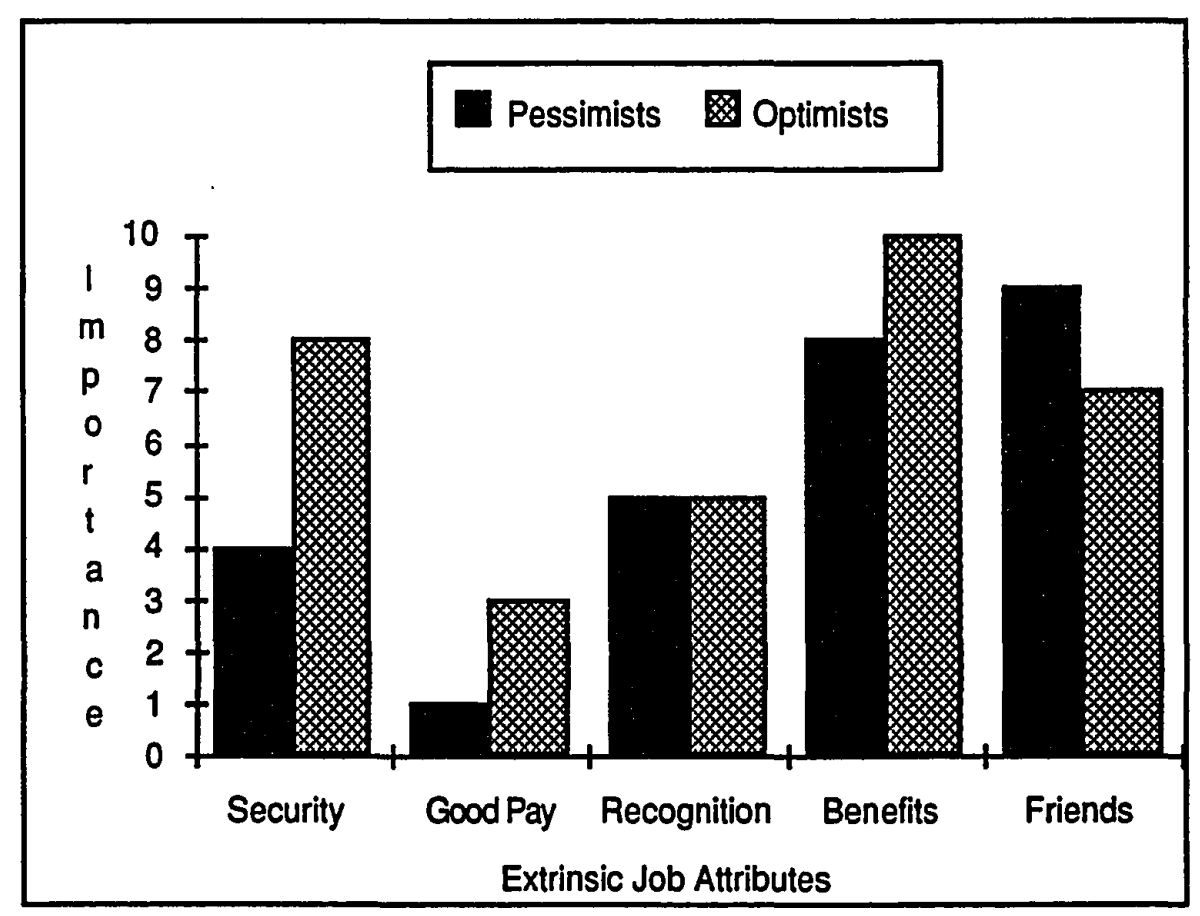

Figure 14. Profile of extrinsic job attributes for pessimists and optimists. Importance ranks of 1 means more important and 10 means less important. 
The results of a MANOVA and T-Tests for the extrinsic job attributes using the Likert importance ratings are summarized in Table XXVI. The pessimists rated three attributes (Security, Good pay, and Benefits) as more important than optimists as predicted and the others (Recognition and Friends) less important than optimists. The differences in the mean ratings for the three attributes (Security, Good pay, and Benefits) between pessimists and optimists are statistically significant at $p<.05$. These results generally support those found using the rank data.

TABLE XXVI

HYPOTHESIS 2A - EXTRINSIC ATTRIBUTES FOR PESSIMISTS AND OPTIMISTS: LIKERT RATING RESULTS

\begin{tabular}{|l|c|c|c|c|c|}
\hline $\begin{array}{c}\text { Extrinsic } \\
\text { Job } \\
\text { Attribute }\end{array}$ & $\begin{array}{c}\text { Mean } \\
\text { Rank } \\
\text { Pessimists } \\
=170\end{array}$ & $\begin{array}{c}\text { Mean } \\
\text { Rank } \\
\text { Optimists } \\
\mathrm{n}=21\end{array}$ & $\begin{array}{c}\text { p value } \\
\text { T-Tests }\end{array}$ & F-value & p-value \\
\hline Security & 3.62 & 3.00 & .03 & 4.87 & .03 \\
\hline Good pay & 4.26 & 3.72 & .01 & 7.14 & .01 \\
\hline Recognition & 3.65 & 3.78 & .60 & 0.91 & .34 \\
\hline Benefits & 3.13 & 2.47 & .02 & 6.02 & .02 \\
\hline Friends & 2.96 & 3.11 & .59 & 0.62 & .43 \\
\hline Multivariate & & & & 2.69 & .02 \\
\hline
\end{tabular}

Note: The higher the value of the rating , the more important the item. A mean rating of 5 is most important and a mean rating of 1 is least important. 
The results of T-tests for the difference of the mean ranks are also summarized in Table XXVI. Three of the attributes (Security, Good pay, and Benefits) were found to be statistically significant at $p<$ .05. The overall results support hypothesis $2 a$. Four of the five attributes (Security, Good pay, Recognition, and Benefits) were found to be different from the predicted direction.

The results of a Mann-Whitney - Wilcoxon Rank Sum W Test for the intrinsic job attributes (hypothesis $2 b$ ) are summarized in Table XXVII. The pessimists ranked all five attributes lower than optimists as predicted. The mean rank differences for two attributes (Develop and Say) were significant at $\mathrm{p}<.05$.

TABLE XXVII

HYPOTHESIS 2B - INTRINSIC ATTRIBUTES FOR PESSIMISTS AND OPTIMISTS: MANN-WHITNEY AND T-TESTS RESULTS

\begin{tabular}{|l|c|c|c|c|c|c|}
\hline $\begin{array}{c}\text { Intrinsic } \\
\text { Job } \\
\text { Attribute }\end{array}$ & $\begin{array}{c}\text { Mean } \\
\text { Rank } \\
\text { Pessimists }\end{array}$ & $\begin{array}{c}\text { Mean } \\
\text { Rank } \\
\text { Optimists }\end{array}$ & $\begin{array}{c}\text { p value } \\
\text { Mann- } \\
\text { Whitney }\end{array}$ & $\begin{array}{c}\text { p value } \\
\text { T-Tests }\end{array}$ & $\begin{array}{c}\text { Relative } \\
\text { Rank } \\
\text { Polish } \\
\text { Pessimists }\end{array}$ & $\begin{array}{c}\text { Relative } \\
\text { Rank } \\
\text { Polish } \\
\text { Optimists }\end{array}$ \\
\hline Results & 4.23 & 3.43 & .23 & .16 & 2 & 2 \\
\hline Interesting & 4.28 & 3.71 & .31 & .33 & 3 & 1 \\
\hline Growing & 7.38 & 6.81 & .40 & .36 & 10 & 9 \\
\hline Develop & 5.86 & 4.57 & .02 & .02 & 6 & 4 \\
\hline Say & 6.96 & 5.62 & .05 & .02 & 7 & 6 \\
\hline
\end{tabular}

Note: The lower the value of the rank (nominal or mean), the more important the item A nominal or mean rank of 1 is most important and a nominal or mean rank of 10 is least important. 
The results of T-tests for significance in the difference of the mean ranks are also summarized in Table XXVII. Only one of the attributes (Develop) was found to be statistically significant at $p<.05$.

The profiles displayed in Figure 15 show that the relative ranks for pessimists for four intrinsics (Interesting, Growing, Develop, and Say) are lower than optimists as predicted. One intrinsic job attribute (Results) was ranked the same for pessimists and optimists.

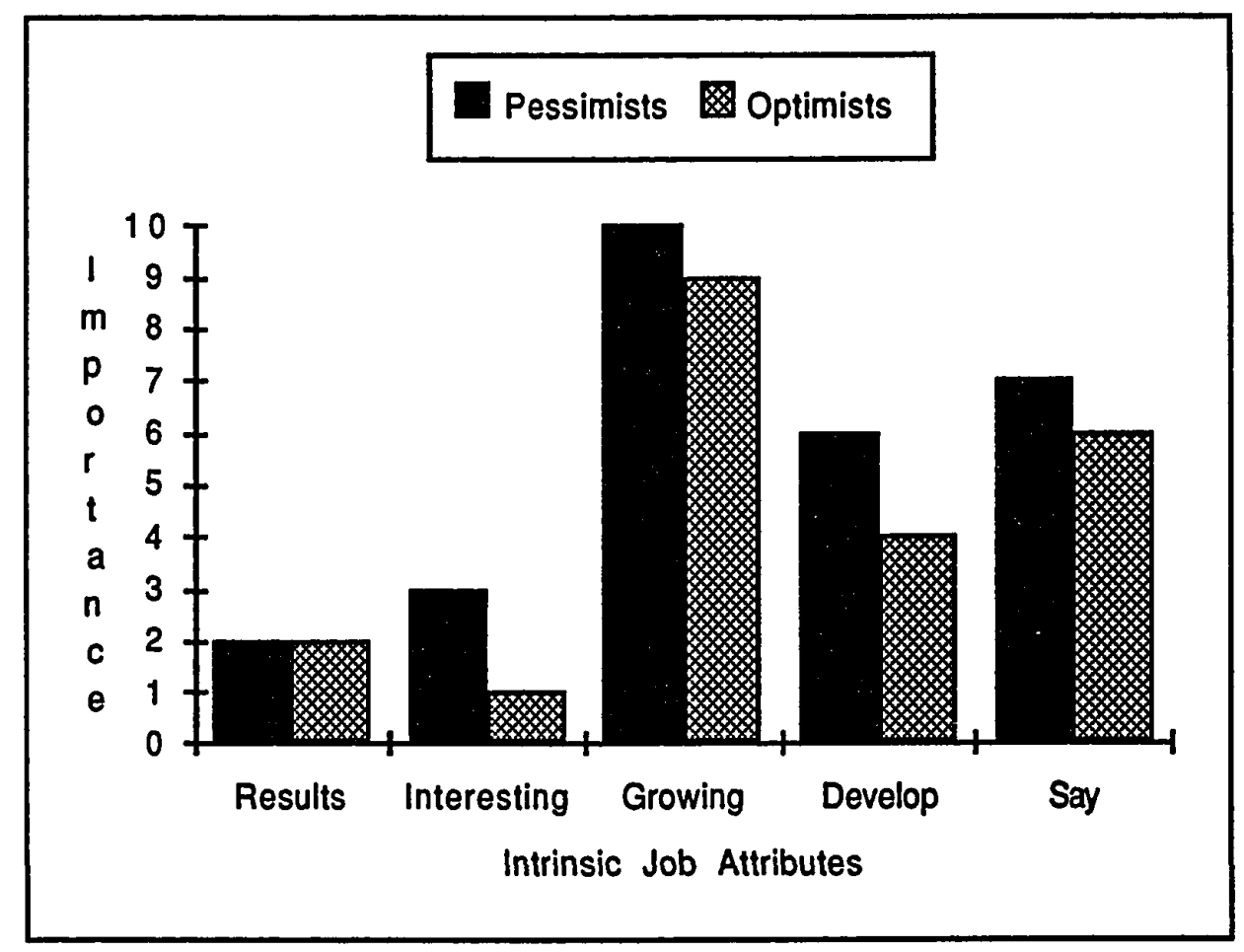

Figure 15. Profile of intrinsic job attributes for pessimists and optimists. Importance ranks of 1 means more important and 10 means less important.

The results of a MANOVA and T-Tests for the intrinsic job attributes using the Likert importance ratings are summarized in 
Table XXVIII. The pessimists rated all five attributes as less important than optimists as predicted. None of differences in the mean ratings are statistically significant at $p<.05$. These results generally support those found using the rank data.

TABLE XXVIII

HYPOTHESIS 2B - INTRINSIC ATTRIBUTES FOR PESSIMISTS AND OPTIMISTS: LIKERT RATING RESULTS

\begin{tabular}{|l|c|c|c|c|c|}
\hline $\begin{array}{c}\text { Intrinsic } \\
\text { Job } \\
\text { Attribute }\end{array}$ & $\begin{array}{c}\text { Mean } \\
\text { Rank } \\
\text { Pessimists }\end{array}$ & $\begin{array}{c}\text { Mean } \\
\text { Rank } \\
\text { Optimists }\end{array}$ & $\begin{array}{c}\text { p value } \\
\text { T-Tests }\end{array}$ & F-value & p-value \\
\hline Results & 3.36 & 3.61 & .29 & 1.16 & .28 \\
\hline Interesting & 3.47 & 3.63 & .50 & 0.87 & .35 \\
\hline Growing & 2.58 & 3.11 & .05 & 3.64 & .06 \\
\hline Develop & 3.25 & 3.42 & .48 & 1.47 & .23 \\
\hline Say & 3.18 & 3.32 & .23 & 0.55 & .46 \\
\hline Multivariate & & & & 1.00 & .42 \\
\hline
\end{tabular}

Note: The higher the value of the rating , the more important the item. A mean rating of 5 is most important and a mean rating of 1 is least important.

The results of T-tests for significance in the difference of the mean ranks are also summarized in Table XXVIII. None of the attributes were found to be statistically significant at $\mathrm{p}<.05$.

The overall results support hypothesis $2 \mathrm{~b}$. All of the five intrinsic job attributes were found to be different in the predicted 
direction. On first examination, hypothesis $2 \mathrm{~b}$ appears to be supported.

In summary for hypothesis 2 , nine of the ten attributes were different for pessimists and optimists in the predicted direction. Hypothesis 2 is supported. This strongly suggests that there is a situational effect (in this case, PES) on job attribute preferences.

\section{RESULTS: POLISH FIRM DIFFERENCES}

(HYPOTHESIS 6)

\section{Hypothesis 6 (a and b)}

a There will be little or no significant differences in workers' job attribute preferences among the five Polish high technology enterprises.

b. There will be significant differences in workers' job attribute preferences among the five Polish high technology enterprises.

Hypothesis 6 was presented as two competing hypotheses -- one predicting no differences in workers' job attribute preferences across the five firms and the other predicting significant differences. Thus, the analysis involves finding evidence that there are significant differences among the five Polish high technology firms.

The results of a MANOVA for the extrinsic job attributes using the Likert importance ratings are summarized in Table XXIX. The multivariate $\mathrm{F}=2.00(\mathrm{p}=.01)$ indicates an overall statistical significant difference among the firms for the extrinsics. Differences in the means for three attributes (Security, Good pay, and Benefits) were found to be significant at $p<.01$. 
TABLE XXIX

HYPOTHESIS 6 - EXTRINSIC ATTRIBUTES FOR FIRMS: LIKERT RATING RESULTS

\begin{tabular}{|l|c|c|c|c|c|c|c|}
\hline $\begin{array}{c}\text { Extrinsic } \\
\text { Job } \\
\text { Attribute }\end{array}$ & $\begin{array}{c}\text { Mean } \\
\text { Rating } \\
\text { Firm V } \\
\mathrm{n}=25\end{array}$ & $\begin{array}{c}\text { Mean } \\
\text { Rating } \\
\text { Firm T } \\
\mathrm{n=37}\end{array}$ & $\begin{array}{c}\text { Mean } \\
\text { Rating } \\
\text { Firm P } \\
\mathrm{n=50}\end{array}$ & $\begin{array}{c}\text { Mean } \\
\text { Rating } \\
\text { Firm I } \\
\mathrm{n=66}\end{array}$ & $\begin{array}{c}\text { Mean } \\
\text { Rating } \\
\text { Firm C } \\
\mathrm{n=51}\end{array}$ & F-value & p-value \\
\hline Security & 2.71 & 3.34 & 3.92 & 3.49 & 3.34 & 5.33 & .00 \\
\hline Good pay & 3.71 & 4.21 & 4.48 & 4.19 & 4.10 & 4.30 & .00 \\
\hline Recognition & 3.67 & 3.55 & 3.74 & 3.64 & 3.48 & 0.59 & .71 \\
\hline Benefits & 2.33 & 3.21 & 3.46 & 2.97 & 2.72 & 5.34 & .00 \\
\hline Friends & 2.88 & 3.13 & 3.02 & 3.00 & 2.88 & 0.36 & .84 \\
\hline Multivariate & & & & & & 2.00 & .01 \\
\hline
\end{tabular}

Note: The higher the value of the rating , the more important the item. A mean rating of 5 is most important and a mean rating of 1 is least important.

The profiles displayed in Figure 16 show that the relative ranks of the firms are approximately equal for the five extrinsic attributes as predicted. Specific larger differences include firms $\mathrm{V}$ and $\mathrm{C}$-Security; and firm P -- Friends.

The results of a MANOVA for the intrinsic job attributes using the Likert importance ratings are summarized in Table XXX. The multivariate $F=2.76(p<.00)$ and univariate results indicate a statistical significant difference among the firms. Differences in the means for two attributes (Growing and Develop) are significant ( $p<$ $.01)$. 
The profiles displayed in Figure 17 present the relative ranks of the intrinsics for the five firms. Specific larger differences include firm I -- Results; firm T -- Interesting; firm P -- Growing; firms V and C -- Develop; and firms V and P -- Say.

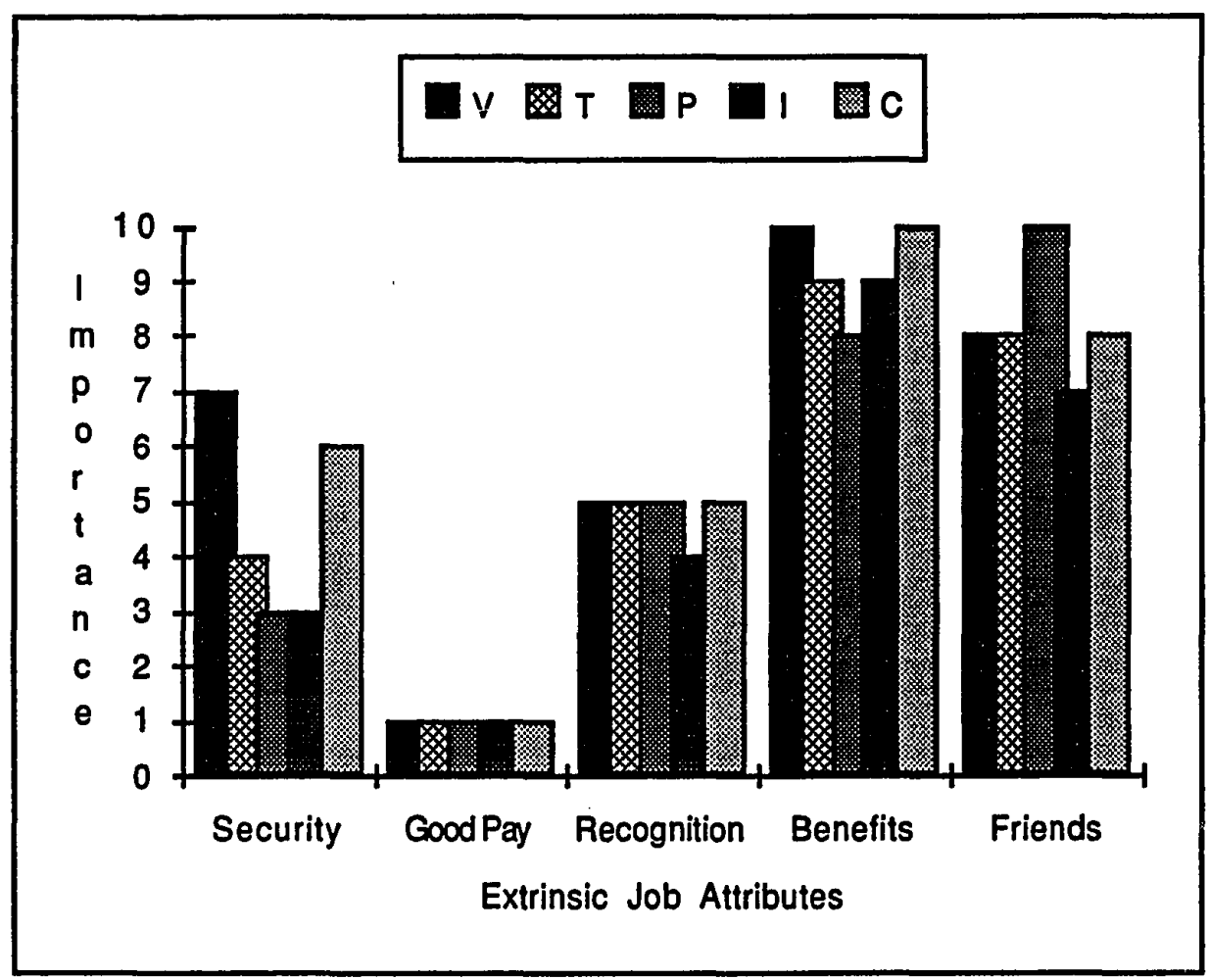

Figure 16. Profile of extrinsic job attributes for five Polish high technology firms. Importance ranks of 1 means more important and 10 means less important.

Overall, five of the ten attributes (Security, Good pay, Benefits, Growing, and Develop) were found to be statistically different. On first examination, hypothesis 6 a appears to be not supported.

A one-way ANOVA was run with the same results. The following differences in means of the attribute ratings for the five firms were 
TABLE XXX

HYPOTHESIS 6 - INTRINSIC ATTRIBUTES FOR FIRMS: LIKERT RATING RESULTS

\begin{tabular}{|l|c|c|c|c|c|c|c|}
\hline $\begin{array}{c}\text { Intrinsic } \\
\text { Job } \\
\text { Attribute }\end{array}$ & $\begin{array}{c}\text { Mean } \\
\text { Rating } \\
\text { Firm V } \\
\mathrm{n}=25\end{array}$ & $\begin{array}{c}\text { Mean } \\
\text { Rating } \\
\text { Firm T } \\
\mathrm{n}=37\end{array}$ & $\begin{array}{c}\text { Mean } \\
\text { Rating } \\
\text { Firm P } \\
\mathrm{n}=50\end{array}$ & $\begin{array}{c}\text { Mean } \\
\text { Rating } \\
\text { Firm I } \\
\text { n=66 }\end{array}$ & $\begin{array}{c}\text { Mean } \\
\text { Fating } \\
\text { F=51 }\end{array}$ & F-value & p-value \\
\hline Results & 3.48 & 3.51 & 3.36 & 3.26 & 3.49 & 0.68 & .61 \\
\hline Interesting & 3.64 & 3.49 & 3.28 & 3.59 & 3.57 & 0.94 & .44 \\
\hline Growing & 2.84 & 2.73 & 3.08 & 2.36 & 2.26 & 5.12 & .00 \\
\hline Develop & 4.08 & 2.97 & 3.38 & 3.25 & 3.35 & 5.63 & .00 \\
\hline Say & 3.16 & 3.24 & 3.00 & 2.97 & 3.14 & 0.61 & .66 \\
\hline Multivariate & & & & & & 2.76 & .00 \\
\hline
\end{tabular}

Note: The higher the value of the rating , the more important the item. A mean rating of 5 is most important and a mean rating of 1 is least important.

found to be significant across the five firms: Security $(F=5.43, p=$ $.00)$, Good pay $(\mathrm{F}=3.93, \mathrm{p}=.00)$, Benefits $(\mathrm{F}=5.34, \mathrm{p}=.00)$, Growing $(F=5.23, p=.00)$, and Develop $(F=6.24, p=.01)$. For Security, the differences were among firms T, P, I and C; for Good pay and Benefits, the differences were among firms T, P, and C; for Growing, the differences were among firms $T, V$, and $P$; and for Develop, the differences were among firms V, P, and C.

In summary for hypothesis 6 , five of the ten attributes had statistically significant differences as predicted in hypothesis $6 b$. Thus, hypothesis $6 \mathrm{~b}$ is supported. 


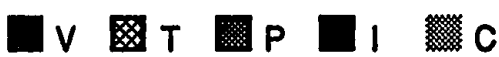

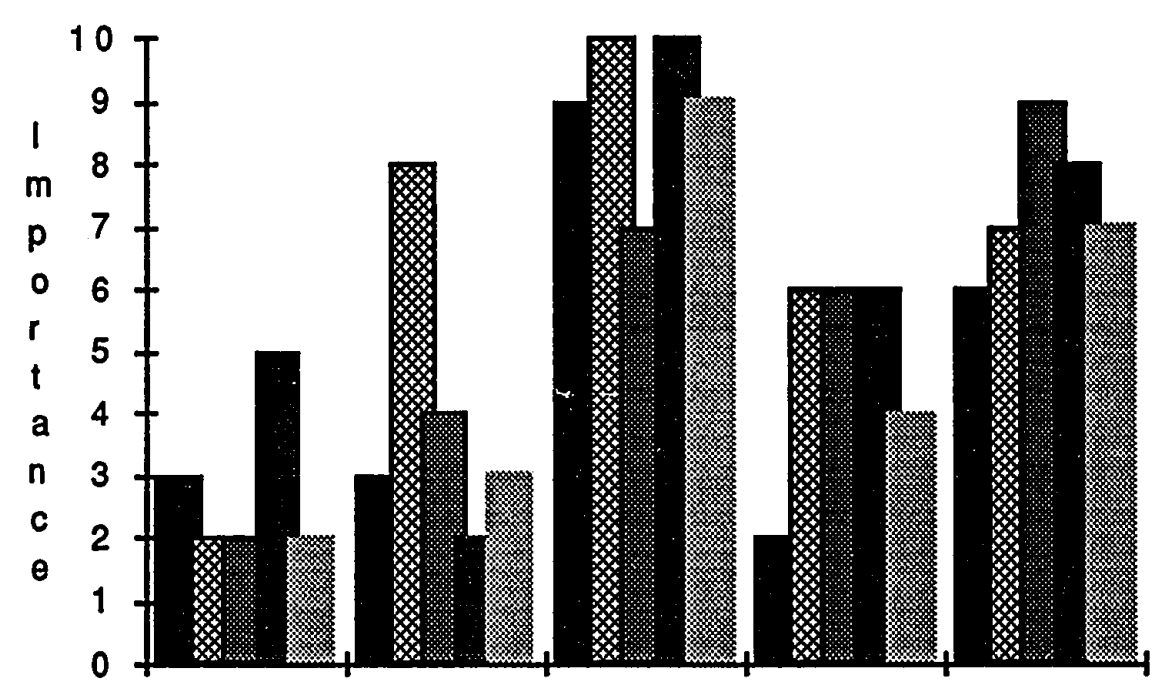

Results Interesting Growing Develop Say Intrinsic Job Attributes

Figure 17. Profile of intrinsic job attributes for five Polish high technology firms. Importance ranks of 1 means more important and 10 means less important.

\section{RESULTS: A SUMMARY (ALL HYPOTHESES)}

Various summaries of the results are presented in this section.

First, the overall results relative to acceptance or rejection of each hypothesis is presented. Then the results are summarized by job attribute clusters (extrinsics and intrinsics) for major groups of hypotheses. This is followed by a cross summary of each job attribute by major groups of hypotheses. 
Overall results: The following summarizes the results for each of the six hypotheses.

- Hypothesis 1 Not supported

- Hypothesis 2 Supported

- Hypothesis 3 Not supported

- Hypothesis 4 Not supported

- Hypothesis 5 Supported

- Hypothesis 6b Supported

Groups of hypotheses' results by attribute clusters: Tables XXXI and XXXII present the results for the intrinsic and extrinsic job attribute clusters, respectively. In each of these tables, the hypotheses are organized in groups as they were analyzed above.

For the intrinsic cluster, Table $\mathrm{XXXI}$, the results for Polish and American workers, Polish and American managers, and Polish workers and managers appear to reject the proposed hypotheses. The results for Pessimistic and optimistic Polish workers and Workers from different Polish firms appear to support the proposed hypotheses.

For the extrinsic cluster, Table XXXII, the results for Polish and American workers, and Polish and American managers appear to reject the proposed hypotheses. The results for Polish workers and managers, Pessimistic and optimistic Polish workers, and Workers from different Polish firms appear to support the proposed hypotheses.

Groups of hypotheses results by individual job attribute: Although the hypotheses were stated in clusters of job attributes, it was implied 
TABLE XXXI

SUMMARY OF THE RESULTS FOR THE INTRINSIC JOB ATTRIBUTE CLUSTERS FOR ALL HYPOTHESES

\begin{tabular}{|c|c|c|}
\hline $\begin{array}{l}\text { Groups of } \\
\text { Hypotheses }\end{array}$ & Predicted direction & Research Direction \\
\hline $\begin{array}{c}\text { Polish and } \\
\text { American workers }\end{array}$ & $\begin{array}{l}\text { More important for } \\
\text { American workers }\end{array}$ & $\begin{array}{l}2 \text { in predicted } \\
\text { direction, } 3 \text { opposite }\end{array}$ \\
\hline $\begin{array}{c}\text { Polish and } \\
\text { American managers }\end{array}$ & $\begin{array}{l}\text { More important for } \\
\text { American managers }\end{array}$ & $\begin{array}{l}3 \text { in predicted } \\
\text { direction, } 2 \text { opposite }\end{array}$ \\
\hline $\begin{array}{l}\text { Polish workers and } \\
\text { managers }\end{array}$ & $\begin{array}{l}\text { More important for } \\
\text { workers' stated } \\
\text { preferences }\end{array}$ & $\begin{array}{l}3 \text { in predicted } \\
\text { direction, } 2 \text { opposite }\end{array}$ \\
\hline $\begin{array}{l}\text { Pessimistic and } \\
\text { optimistic Polish } \\
\text { workers }\end{array}$ & $\begin{array}{l}\text { More important for } \\
\text { optimists }\end{array}$ & $\begin{array}{l}5 \text { in predicted } \\
\text { direction }\end{array}$ \\
\hline $\begin{array}{l}\text { Workers from } \\
\text { different Polish } \\
\text { firms }\end{array}$ & $\begin{array}{l}\text { About the same for } \\
\text { all firms }\end{array}$ & $\begin{array}{l}\text { No significant } \\
\text { difference in } 3 \text { items } \\
\text { and slight in other } \\
\text { two }\end{array}$ \\
\hline
\end{tabular}

that predictions were made for each individual job attribute. Thus, it is instructive to review the results for each attribute.

Tables XXXIII and XXXXII present the results for each of the ten job attributes, respectively. In each of these tables, the hypotheses are organized in groups as they were analyzed above. The "Research Direction" presented represents the predominant direction and may not be statistically correct for all cases. These results tables are presented here and discussed in the next section. 
Table XXXIII presents the results for the Results job attribute.

Except for Polish and American managers the results are as predicted.

TABLE XXXII

SUMMARY OF THE RESULTS FOR THE EXTRINSIC JOB ATTRIBUTE CLUSTERS FOR ALL HYPOTHESES

\begin{tabular}{|c|c|c|}
\hline $\begin{array}{l}\text { Groups of } \\
\text { Hypotheses }\end{array}$ & Predicted direction & Research Direction \\
\hline $\begin{array}{c}\text { Polish and } \\
\text { American workers }\end{array}$ & $\begin{array}{l}\text { More important for } \\
\text { Polish workers }\end{array}$ & $\begin{array}{l}2 \text { in predicted } \\
\text { direction, } 3 \text { opposite }\end{array}$ \\
\hline $\begin{array}{l}\text { Pollsh and } \\
\text { American managers }\end{array}$ & $\begin{array}{l}\text { More Important for } \\
\text { Polish managers }\end{array}$ & $\begin{array}{c}3 \text { in predicted } \\
\text { direction, } 2 \text { opposite }\end{array}$ \\
\hline $\begin{array}{l}\text { Pollsh workers and } \\
\text { managers }\end{array}$ & $\begin{array}{l}\text { About the same for } \\
\text { workers and } \\
\text { managers }\end{array}$ & $\begin{array}{l}\text { As predicted for } 4 \\
\text { Items }\end{array}$ \\
\hline $\begin{array}{l}\text { Pessimistic and } \\
\text { optimistic Polish } \\
\text { workers }\end{array}$ & $\begin{array}{l}\text { More important for } \\
\text { pessimists }\end{array}$ & $\begin{array}{l}\text { As predicted for } 4 \\
\text { items }\end{array}$ \\
\hline $\begin{array}{l}\text { Workers from } \\
\text { different Polish } \\
\text { firms }\end{array}$ & $\begin{array}{l}\text { About the same for } \\
\text { all firms }\end{array}$ & $\begin{array}{l}\text { No significant } \\
\text { difference in } 3 \text { tems } \\
\text { and sllght in one } \\
\text { other }\end{array}$ \\
\hline
\end{tabular}

Table XXXIV presents the results for the Interesting job attribute. Except for Polish and American workers and Polish and American managers, the results are as predicted.

Table XXXV presents the results for the Growing job attribute. Except for Polish workers and managers, the results are as predicted. 
Table XXXVI presents the results for the Develop job attribute. Except for Pessimistic and optimistic Polish workers, the results are opposite those predicted.

Table XXXVII presents the results for the Say job attribute. In all cases, the results are as predicted.

Table XXXVIII presents the results for the Security job attribute. Except for Polish and American workers and Workers from different Polish firms, the results are as predicted.

Table XXXIX presents the results for the Good pay job attribute. Except for Polish and American workers and Workers from different Polish firms, the results are as predicted.

Table XXXX presents the results for the Recognition job attribute. The results in all cases, except Workers from different Polish firms, are as predicted.

Table XXXXI presents the results for the Benefits job attribute. In three groups, Polish and American workers, Polish workers and managers, and Workers from different Polish firms, the results are opposite those predicted.

Table XXXXII presents the results for the Friends job attribute. Results for three groups of hypotheses, Polish and American workers, Polish and American managers, and Pessimistic and optimistic Polish workers were as predicted and the two other groups of hypotheses, Polish workers and managers and Workers from different Polish firms, were in the opposite direction. 
TABLE XXXIII

SUMMARY OF THE RESULTS FOR THE RESULTS JOB ATTRIBUTE FOR ALL HYPOTHESES

\begin{tabular}{|c|c|c|}
\hline $\begin{array}{l}\text { Groups of } \\
\text { Hypotheses }\end{array}$ & Predicted direction & Research Direction \\
\hline $\begin{array}{l}\text { Polish and } \\
\text { American workers }\end{array}$ & $\begin{array}{l}\text { More important for } \\
\text { American workers }\end{array}$ & As predicted \\
\hline $\begin{array}{l}\text { Polish and } \\
\text { American managers }\end{array}$ & $\begin{array}{l}\text { More important for } \\
\text { American managers }\end{array}$ & Opposite \\
\hline $\begin{array}{l}\text { Polish workers and } \\
\text { managers }\end{array}$ & $\begin{array}{l}\text { More important for } \\
\text { workers' stated } \\
\text { preferences }\end{array}$ & As predicted \\
\hline $\begin{array}{l}\text { Pessimistic and } \\
\text { optimistic Polish } \\
\text { workers }\end{array}$ & $\begin{array}{l}\text { More important for } \\
\text { optimists }\end{array}$ & As predicted \\
\hline $\begin{array}{l}\text { Workers from } \\
\text { different Polish } \\
\text { firms }\end{array}$ & $\begin{array}{l}\text { About the same for } \\
\text { all firms }\end{array}$ & As predicted \\
\hline
\end{tabular}


TABLE XXXIV

SUMMARY OF THE RESULTS FOR THE INTERESTING JOB ATTRIBUTE FOR ALL HYPOTHESES

\begin{tabular}{|c|c|c|}
\hline $\begin{array}{l}\text { Groups of } \\
\text { Hypotheses }\end{array}$ & Predicted direction & Research Direction \\
\hline $\begin{array}{l}\text { Polish and } \\
\text { American workers }\end{array}$ & $\begin{array}{l}\text { More important for } \\
\text { American workers }\end{array}$ & Opposite \\
\hline $\begin{array}{c}\text { Polish and } \\
\text { American managers }\end{array}$ & $\begin{array}{l}\text { More important for } \\
\text { American managers }\end{array}$ & Opposite \\
\hline $\begin{array}{l}\text { Polish workers and } \\
\text { managers }\end{array}$ & $\begin{array}{l}\text { More important for } \\
\text { workers' stated } \\
\text { preferences }\end{array}$ & As predicted \\
\hline $\begin{array}{l}\text { Pessimistic and } \\
\text { optimistic Polish } \\
\text { workers }\end{array}$ & $\begin{array}{l}\text { More important for } \\
\text { optimists }\end{array}$ & As predicted \\
\hline $\begin{array}{l}\text { Workers from } \\
\text { different Polish } \\
\text { firms }\end{array}$ & $\begin{array}{l}\text { About the same for } \\
\text { all firms }\end{array}$ & As predicted \\
\hline
\end{tabular}


TABLE XXXV

SUMMARY OF THE RESULTS FOR THE GROWING JOB ATTRIBUTE FOR ALL HYPOTHESES

\begin{tabular}{|c|c|c|}
\hline $\begin{array}{l}\text { Groups of } \\
\text { Hypotheses }\end{array}$ & Predicted direction & Research Direction \\
\hline $\begin{array}{c}\text { Polish and } \\
\text { American workers }\end{array}$ & $\begin{array}{l}\text { More important for } \\
\text { American workers }\end{array}$ & As predicted \\
\hline $\begin{array}{c}\text { Polish and } \\
\text { American managers }\end{array}$ & $\begin{array}{l}\text { More important for } \\
\text { American managers }\end{array}$ & As predicted \\
\hline $\begin{array}{l}\text { Polish workers and } \\
\text { managers }\end{array}$ & $\begin{array}{l}\text { More important for } \\
\text { workers' stated } \\
\text { preferences }\end{array}$ & Opposite \\
\hline $\begin{array}{c}\text { Pessimistic and } \\
\text { optimistic Polish } \\
\text { workers }\end{array}$ & $\begin{array}{l}\text { More important for } \\
\text { optimists }\end{array}$ & As predicted \\
\hline $\begin{array}{l}\text { Workers from } \\
\text { different Polish } \\
\text { firms }\end{array}$ & $\begin{array}{l}\text { About the same for } \\
\text { all firms }\end{array}$ & As predicted \\
\hline
\end{tabular}


TABLE XXXVI

SUMMARY OF THE RESULTS FOR THE DEVELOP JOB ATTRIBUTE FOR ALL HYPOTHESES

\begin{tabular}{|c|c|c|}
\hline $\begin{array}{c}\text { Groups of } \\
\text { Hypotheses }\end{array}$ & Predicted direction & Research Direction \\
\hline $\begin{array}{c}\text { Polish and } \\
\text { American workers }\end{array}$ & $\begin{array}{c}\text { More important for } \\
\text { American workers }\end{array}$ & Opposite \\
\hline $\begin{array}{c}\text { Polish and } \\
\text { American managers }\end{array}$ & $\begin{array}{c}\text { More important for } \\
\text { American managers }\end{array}$ & Opposite \\
\hline $\begin{array}{c}\text { Polish workers and } \\
\text { managers }\end{array}$ & $\begin{array}{c}\text { More important for } \\
\text { workers' stated } \\
\text { preferences }\end{array}$ & Opposite \\
\hline $\begin{array}{c}\text { Pessimistic and } \\
\text { optimistic Polish } \\
\text { workers }\end{array}$ & $\begin{array}{c}\text { More important for } \\
\text { optimists }\end{array}$ & As predicted \\
\hline $\begin{array}{c}\text { Workers from } \\
\text { different Polish } \\
\text { firms }\end{array}$ & $\begin{array}{c}\text { About the same for } \\
\text { all firms }\end{array}$ & Opposite \\
\hline
\end{tabular}


TABLE XXXVII

SUMMARY OF RESULTS FOR THE SAY JOB ATTRIBUTE FOR ALL HYPOTHESES

\begin{tabular}{|c|c|c|}
\hline $\begin{array}{l}\text { Groups of } \\
\text { Hypotheses }\end{array}$ & Predicted direction & Research Direction \\
\hline $\begin{array}{l}\text { Polish and } \\
\text { American workers }\end{array}$ & $\begin{array}{l}\text { More important for } \\
\text { American workers }\end{array}$ & As predicted \\
\hline $\begin{array}{c}\text { Polish and } \\
\text { American managers }\end{array}$ & $\begin{array}{l}\text { More important for } \\
\text { American managers }\end{array}$ & As predicted \\
\hline $\begin{array}{l}\text { Polish workers and } \\
\text { managers }\end{array}$ & $\begin{array}{l}\text { More important for } \\
\text { workers' stated } \\
\text { preferences }\end{array}$ & As predicted \\
\hline $\begin{array}{l}\text { Pessimistic and } \\
\text { optimistic Polish } \\
\text { workers }\end{array}$ & $\begin{array}{l}\text { More important for } \\
\text { optimists }\end{array}$ & As predicted \\
\hline $\begin{array}{l}\text { Workers from } \\
\text { different Polish } \\
\text { firms }\end{array}$ & $\begin{array}{l}\text { About the same for } \\
\text { all firms }\end{array}$ & As predicted \\
\hline
\end{tabular}


TABLE XXXVIII

SUMMARY OF RESULTS FOR THE SECURITY JOB ATTRIBUTE FOR ALL HYPOTHESES

\begin{tabular}{|c|c|c|}
\hline $\begin{array}{l}\text { Groups of } \\
\text { Hypotheses }\end{array}$ & Predicted direction & Research Direction \\
\hline $\begin{array}{l}\text { Polish and } \\
\text { American workers }\end{array}$ & $\begin{array}{l}\text { More important for } \\
\text { Polish workers }\end{array}$ & Opposite \\
\hline $\begin{array}{c}\text { Polish and } \\
\text { American managers }\end{array}$ & $\begin{array}{l}\text { More important for } \\
\text { Polish managers }\end{array}$ & As predicted \\
\hline $\begin{array}{l}\text { Polish workers and } \\
\text { managers }\end{array}$ & $\begin{array}{l}\text { About the same for } \\
\text { workers and } \\
\text { managers }\end{array}$ & As predicted \\
\hline $\begin{array}{l}\text { Pessimistic and } \\
\text { optimistic Polish } \\
\text { workers }\end{array}$ & $\begin{array}{l}\text { More important for } \\
\text { pessimists }\end{array}$ & As predicted \\
\hline $\begin{array}{l}\text { Workers from } \\
\text { different Polish } \\
\text { firms }\end{array}$ & $\begin{array}{l}\text { About the same for } \\
\text { all firms }\end{array}$ & Opposite \\
\hline
\end{tabular}


TABLE XXXIX

SUMMARY OF RESULTS FOR THE GOOD PAY JOB ATTRIBUTE FOR ALL HYPOTHESES

\begin{tabular}{|c|c|c|}
\hline $\begin{array}{l}\text { Groups of } \\
\text { Hypotheses }\end{array}$ & Pyedicted direction & Research Direction \\
\hline $\begin{array}{l}\text { Polish and } \\
\text { Amerlcan workers }\end{array}$ & $\begin{array}{l}\text { More important for } \\
\text { Polish workers }\end{array}$ & Opposite \\
\hline $\begin{array}{c}\text { Polish and } \\
\text { American managers }\end{array}$ & $\begin{array}{l}\text { More important for } \\
\text { Polish managers }\end{array}$ & As predicted \\
\hline $\begin{array}{l}\text { Polish workers and } \\
\text { managers }\end{array}$ & $\begin{array}{l}\text { About the same for } \\
\text { workers and } \\
\text { managers }\end{array}$ & As predicted \\
\hline $\begin{array}{l}\text { Pessimistic and } \\
\text { optimistic Polish } \\
\text { workers }\end{array}$ & $\begin{array}{l}\text { More important for } \\
\text { pessimists }\end{array}$ & As predicted \\
\hline $\begin{array}{l}\text { Workers from } \\
\text { different Polish } \\
\text { firms }\end{array}$ & $\begin{array}{l}\text { About the same for } \\
\text { all firms }\end{array}$ & Opposite \\
\hline
\end{tabular}


TABLE XXXX

SUMMARY OF RESULTS FOR THE RECOGNITION JOB ATTRIBUTE FOR ALL HYPOTHESES

\begin{tabular}{|c|c|c|}
\hline $\begin{array}{l}\text { Groups of } \\
\text { Hypotheses }\end{array}$ & Predicted direction & Research Direction \\
\hline $\begin{array}{l}\text { Polish and } \\
\text { Amerlcan workers }\end{array}$ & $\begin{array}{l}\text { More important for } \\
\text { Polish workers }\end{array}$ & As predicted \\
\hline $\begin{array}{c}\text { Polish and } \\
\text { American managers }\end{array}$ & $\begin{array}{l}\text { More important for } \\
\text { Polish managers }\end{array}$ & As predicted \\
\hline $\begin{array}{c}\text { Polish workers and } \\
\text { managers }\end{array}$ & $\begin{array}{l}\text { About the same for } \\
\text { workers and } \\
\text { managers }\end{array}$ & As predicted \\
\hline $\begin{array}{c}\text { Pessimistic and } \\
\text { optimistic Polish } \\
\text { workers }\end{array}$ & $\begin{array}{l}\text { More important for } \\
\text { pessimists }\end{array}$ & As predicted \\
\hline $\begin{array}{l}\text { Workers from } \\
\text { different Polish } \\
\text { firms }\end{array}$ & $\begin{array}{l}\text { About the same for } \\
\text { all firms }\end{array}$ & Opposite \\
\hline
\end{tabular}


TABLE XXXXI

SUMMARY OF RESULTS FOR THE BENEFITS JOB ATTRIBUTE FOR ALL HYPOTHESES

\begin{tabular}{|c|c|c|}
\hline $\begin{array}{c}\text { Groups of } \\
\text { Hypotheses }\end{array}$ & Predicted direction & Research Direction \\
\hline $\begin{array}{c}\text { Polish and } \\
\text { American workers }\end{array}$ & $\begin{array}{c}\text { More important for } \\
\text { Polish workers }\end{array}$ & Opposite \\
\hline $\begin{array}{c}\text { Polish and } \\
\text { American managers }\end{array}$ & $\begin{array}{c}\text { More important for } \\
\text { Polish managers }\end{array}$ & As predicted \\
\hline $\begin{array}{c}\text { Polish workers and } \\
\text { managers }\end{array}$ & $\begin{array}{c}\text { About the same for } \\
\text { workers and } \\
\text { managers }\end{array}$ & Opposite \\
\hline $\begin{array}{c}\text { Pessimistic and } \\
\text { optimistic Polish } \\
\text { workers }\end{array}$ & $\begin{array}{c}\text { More important for } \\
\text { pessimists }\end{array}$ & As predicted \\
\hline $\begin{array}{c}\text { Workers from } \\
\text { different Polish } \\
\text { firms }\end{array}$ & $\begin{array}{c}\text { About the same for } \\
\text { all firms }\end{array}$ & Opposite \\
\hline
\end{tabular}


TABLE XXXXII

SUMMARY OF RESULTS FOR FRIENDS JOB ATTRIBUTE FOR ALL HYPOTHESES

\begin{tabular}{|c|c|c|}
\hline $\begin{array}{l}\text { Groups of } \\
\text { Hypotheses }\end{array}$ & Predicted direction & Research Direction \\
\hline $\begin{array}{l}\text { Polish and } \\
\text { American workers }\end{array}$ & $\begin{array}{l}\text { More important for } \\
\text { Polish workers }\end{array}$ & As predicted \\
\hline $\begin{array}{c}\text { Polish and } \\
\text { American managers }\end{array}$ & $\begin{array}{l}\text { More important for } \\
\text { Polish managers }\end{array}$ & As predicted \\
\hline $\begin{array}{l}\text { Polish workers and } \\
\text { managers }\end{array}$ & $\begin{array}{l}\text { About the same for } \\
\text { workers and } \\
\text { managers }\end{array}$ & Opposite \\
\hline $\begin{array}{l}\text { Pessimistic and } \\
\text { optimistic Polish } \\
\text { workers }\end{array}$ & $\begin{array}{l}\text { More important for } \\
\text { pessimists }\end{array}$ & As predicted \\
\hline $\begin{array}{l}\text { Workers from } \\
\text { different Polish } \\
\text { firms }\end{array}$ & $\begin{array}{l}\text { About the same for } \\
\text { all firms }\end{array}$ & Opposite \\
\hline
\end{tabular}




\section{CHAPTER V}

\section{DISCUSSION}

This chapter summarize the findings and discusses the implications on managerial practices in Poland, and future research on job attribute preferences. Limitations are first discussed, followed by key findings, implications for job attribute preference research and management practices, and conclusions.

\section{LIMITATIONS}

It should be recognized that this research is not an experiment but a survey of five high technology firms in Poland during a turbulent period of national transition to a free-market economy. The sample is not representative of every manager and worker in Poland, but does represent the situation in high technology firms at one point in time that can be compared with data collected in America. The results should offer some help to Polish managers and American investors in forming motivational policies and programs, and to Western educators and researchers on the applicability of Western theories in Poland.

The research approach of using job attribute preferences does not directly predict required motivational characteristics of individuals or groups of workers and managers. It does, however, 
present useful data regarding workers' preferences that can help in forming more appropriate motivational policies.

\section{KEY FINDINGS}

The results presented in the last section were often in contrast to the definitive results of American based studies and were contrary to some of the proposed hypotheses. Clearly, the Polish situation of today is different, and perhaps the differences are even more dramatic than anyone has imagined or theorized. This is consistent with Hofstede's (1980) research that concluded work values were cultural variables, programming the human mind through such things as family, organizations, etc.

"Optimists" versus "pessimists:" This research found that optimists (those workers who tended to be optimistic about their personal economic situation) rated all five of the intrinsic job attributes higher and four of the five extrinsic job attributes lower than pessimists (those workers who tend to be pessimists about their personal economic situation), as was expected. Friends was rated in the opposite direction for reasons discussed later. The results for pessimists and optimists were consistent with a Maslow-type needs hierarchy and logically understandable. Maslow (1970: 36-37) stated:

Undoubtedly these physiological needs are the most prepotent of all needs. What this means specifically is that in the human being who is missing everything in life in an extreme fashion, it is most likely that the major motivation would be the physiological needs, rather than any others. A person who is lacking food, safety, love, and esteem would most probably hunger for food more strongly than for anything else. 
The results from this research clearly support Maslow's prepotency theory and strongly suggests that there was a situational effect (in this case, PES) on job attribute preferences.

Differences among firms: The multivariates for the extrinsic and intrinsic clusters were found to be significant across the five firms. When Firm $\mathrm{V}$ was removed from the analysis, the intrinsics multivariate was still significant (but with only one significant attribute -- Growing) and the extrinsics multivariate was not significant. Firm V is the only truly private firm, while the other four firms have operated in the past under central planning where many of the pre-transition policies and behaviors still exist. Thus, the results of this research tend to support the theory discussed by Linstone (1988) regarding the strong organizational affect on the individuals within the firm.

The similarities across such a wide array of size and ownership, was noteworthy. Key to this tendency towards homogeneity was the lingering reality of the past regime. It may take generations before strong enterprise leadership and weakened central control produces enterprises with the heterogeneous nature that exists in the U.S.

Polish versus American managers and workers: The results comparing Americans and Poles were mixed and contrary to the hypotheses. Three intrinsic job attributes (Results, Interesting, and Say) were more important to Polish workers and managers versus their American counterparts even though their standards of living were very low and their day to day life often filled with activities aimed at satisfying physiological and safety needs. This suggests a pent up need for intrinsic-type motivational policies for Polish workers. 
Thus, it is possible that, in this situation, pay levels are so tightly coupled to incentives that the Results attribute behaves more like an extrinsic rather than an intrinsic attribute. With this possibility, the above results would be as predicted (the Results attribute higher ranked by Poles). It is also possible that the contrary results for the Say attribute could be explained by a reaction to the suppression which existed for 50 years in Poland. Workers and managers may now feel a strong need to participate in the business and their work.

The Interesting attribute appeared to be very important to Poles. Most workers have had the same job in the same company for many years, making an interesting job an un-met and a high priority.

Polish managers' perception of workers' preferences and workers' stated preferences: At the center of this study, the potential "mismatch" of managers' perception of workers' job attribute preferences, the results appeared to confirm that Polish managers are more in touch with their workers' than American managers. This was predicted for the extrinsic job attributes, but not for the intrinsics.

For the extrinsic attributes, only the Friends attribute was statistically different between managers' perception and workers' preferences. The situation with Friends in Polish firms is different than in America. This is discussed in detail later in this section.

None of the intrinsic attributes had statistically significant differences. In other words, Polish managers accurately predicted worker job attribute preferences. This is in stark contrast to the American results where managers systematically underestimated the importance of the intrinsic job attributes to workers and 
overestimated extrinsics. It suggests that considerable caution be used when applying Western theories and research results to Poland and potentially other Eastern European countries.

Individual job attributes: The job attributes were clustered into two groups (intrinsic and extrinsic) as has been done in the American research. However, the results of this research suggests that the attributes do not operate as a group but appear to be independent.

The items used in this research are regarded as among the most important job attributes. This research challenges these concepts. The pattern in Poland was different. Job attribute preferences such as Benefits and Friends appeared to be less a function of the job and more a function of the Polish society (the supra-system). They were not a simple function of intrinsics and extrinsics as they appeared to be in America. It is possible that countries and cultures have their own sets of "top 10s."

In an attempt to develop a single dimension for the extrinsic job attributes, the creation of scale using the five items was examined. A reliability alpha of .5236 was calculated. The maximum reliability alpha, with one item removed (Recognition) was .540. A similar scale for intrinsics was examined. Here, the maximum alpha, with one item removed (Develop) was -.058 . These reliability alphas were judged to be too weak for a single dimension scale for extrinsics or intrinsics. To further illustrate this point, the following elaborates and discusses the results for individual job attribute preferences. Data from the focus interviews of Polish managers on motivational practices and systems were integrated throughout this section. 
Intrinsic job attributes which appear to be the same in Poland: The results for the attributes Growing (Being in a growing industry) and Say (having a say in the job) appeared to be ranked as predicted and consistent with American results.

Intrinsic job attributes which appear to be different in Poland: Three attributes, Results (seeing the results of my work), Interesting (having interesting work), and Develop (developing skills and abilities) appeared to be very different in Poland.

Contrary to predictions, the Results job attribute was significantly more important for Polish workers and managers than for their American counterparts. Focus interviews with Polish managers provided a possible explanation. Almost without exception, all workers and managers had their pay tied to meeting specific objectives. It is possible that this job attribute, which was considered as intrinsic in America, has been interpreted as extrinsic in Poland because of its very tight coupling with pay.

Also contrary to predictions, the Interesting job attribute was significantly more important for Polish workers and managers than for their American counterparts. Focus interviews with Polish managers provided a possible explanation. Almost without exception, all workers and managers had very long tenure in their job. Transfers were almost unheard of and management track was strongly tied to party affiliation in the past.

The Develop job attribute had the most mixed results. Except for the pessimist/optimist comparison, Develop was contrary to the predicted direction in all other comparisons. In most cases, the 
differences were not significant. Interviews with management indicated that virtually no formal or informal job education exists for workers or managers. Further insight was possible when the realities of the past socialist policies were included. After World War II, the quality of products decreased considerably not solely because of the "system," but largely because most of the production was taken to Russia and the Poles didn't like the Russians. In addition, everyone was expected to be "average" and anyone who tried to improve him or her self was beaten down by the system and their fellow workers. Thus, there were significant disincentives to develop one's skills and abilities. Although there have been changes in recent years, this attitude is still heard often on the streets and in the enterprises.

Extrinsic job attributes which appear to be the same in Poland: Recognition (getting recognition for good work) was ranked about as predicted in all cases.

Extrinsic job attributes which appear to be different in Poland: Four of the extrinsic job attributes, Security (having a secure job), Good pay (having good pay), Benefits (having good pensions and other benefits), and Friends (having friends at work) appeared to be different in Poland than was predicted.

The Security job attribute ranked about as predicted except where Polish and American workers were compared. Contrary to prediction, Polish workers ranked Security lower than American workers. A possible explanation can be found in the past, when Poles were guaranteed $a$ job and there was no unemployment. This made job security a non-issue for most Polish workers and managers. It is 
also possible that the workers that were still at these Polish companies felt that they were secure because there had been lay-offs and they were still with the firm.

Another possible explanation could be that the sample of American workers was less experienced (the mean tenure for the American and Polish workers was 4.5 and 14.3 years, respectively) and younger (data were unavailable for Americans, but it is possible that they were younger) than the sample of their Polish counterparts. The Polish results suggest that younger and less experienced workers were more optimistic and rated the extrinsic job attributes lower than the older, less experienced workers. Thus, if it was possible to control for age and tenure for both sets of data, the results comparing the younger, less experienced, and more optimistic workers from America and Poland might possibly have been the same as predicted.

The Good pay job attribute ranked about as predicted except where Polish and American workers were compared. American workers ranked Good pay higher than Polish workers, but both ranked Good pay as the most important job attribute. The difference was small and not statistically significant.

The results for the Benefits job attribute were mixed. Interviews with Polish managers uncovered significant differences between Benefits in Poland and America. All firms in Poland were required by the state to offer the same benefits package to all workers and managers. Thus, it is possible that Poles consistently ranked Benefits lower than predicted because it was a non-issue in the current Polish economic situation. 
The results for the Friends job attribute were generally consistent with prediction. Poles ranked Friends higher than their American counterparts. However, interviews with Polish managers uncovered significant differences between Friends in Poland and America. All of the firms in Poland stated that workers and managers seldom had friends at work. Very few "social" activities occurred and managers thought that these activities were not part of the work experience. Another factor from the past regime that was interesting to note was the law regarding illegal meetings. In the 1970 s, it was illegal to have meeting with 4 or more people in attendance. Thus, perhaps the severe penalties for disobedience to this law still lingers in the factories while the "natural" desire for friendships was translated into higher ranking for Poles in this research.

Summary: Reviewing the findings as a whole presents an interesting "big picture" -- all workers and managers in Poland and America appear to have the same basic motivational make-up with some subtle differences.

All four groups (Polish and American managers and workers) rank the top and bottom clusters of job attributes about the same. The differences are in the middle cluster of attributes and, interestingly, particular to American workers. That is, the pattern of ranked attributes for Polish managers, American managers, and Polish workers are virtually the same while the American workers' pattern is distinctly different in the middle cluster.

All workers and managers rank good pay and an interesting job in the highest cluster of job attributes. They also rank having friends, 
having a say about their job, and having a position in a growing industry in the lowest cluster of attributes. For the middle cluster, American workers rank getting recognition and seeing the results of their work much lower, and job security and benefits much higher than Polish managers, Polish workers, and American managers. As discussed above, these differences could be explained by environmental conditions.

It appears that the fundamental nature of workers and managers is basically the same in Poland and America. Good pay is always ranked first, followed by a mixture of extrinsic and intrinsic attributes, and ending with a couple of extrinsic attributes. Once pay becomes a non-issue, all workers and managers want to have meaningful work and make a contribution in a secure and growing environment. The primary differences revealed in this dissertation appear to be structural in nature, depending upon the environment outside of the work place.

\section{IMPLICATIONS FOR JOB ATTRIBUTE PREFERENCE RESEARCH}

This study has advanced the research in job attribute preferences and has produced possibly the first study of its kind in Poland. The following are implications for future research.

A systems science approach is necessary in order to fully understand the complex issues addressed in this type of research. A non-systems approach to researching job attribute preferences can yield incomplete analysis and potentially incorrect solutions. The 
systems science approach has permitted a deeper understanding, particularly at the supra-system level, by collecting data regarding motivational policies at the organization and societal levels and concluding that there is a strong organizational effect among the five firms in this study.

Organizational variables and policies have a clear impact on worker and manager work activities. In particular, this research found significant effects in the area of Friends, Benefits, Develop, and others from specific enterprise and government policies and activities. This research clearly points to the need to collect data at the sub-system level. The results regarding the impact of the personal economic situation are clear and perhaps the most conclusive in this study.

Future research using job attribute preferences should recognize that there may not be a universal "top 10" list of extrinsic and intrinsic job attribute preferences. Researchers need to be careful in selecting attributes that are important to the situation (culture, country, transitional nature, etc.). The measures, and management styles and methods developed in the U.S. should not be automatically used in the current Polish environment or perhaps in any of the countries going through the transition to a free market economy.

Although the Likert importance scales added credibility to the analysis in this study, the results were generally the same as those using the forced ranks. Thus, situations where language, time, or complexity may be a factor, the Likert scale could be dropped.

A personal economic situation (PES) scale was created which might have applicability in a wide range of different research studies, 
particularly with job attribute preferences. It appears clear that many of the Polish attitudes towards job attribute preferences were impacted by situational variables rather than being universally stable.

This research suggests that the basic concept of intrinsics may be fallible. There is evidence to believe that some of the key intrinsic attributes may only exist in an extrinsic frame. For example, this study has found that Results in Poland may to be driven by external policies (pay for results), Develop may be distorted and arrested by disincentives to be better than "average," Growing may not even exist in an environment where everyone joins the local factory for life and mobility in impossible because of the lack of housing.

The author would encourage researchers to study Poland and other former Iron Curtain countries. The respondents actively participated and were excited that someone had the interest to ask their opinions. Top management enthusiastically supported the activity and encouraged the author to continue with other studies.

The review of the literature revealed a scarcity of empirical studies in this particular area. The author hopes that this study will be a step toward more research on the topic of Polish high technology organizations. There are several additional studies that need to be conducted, including the following:

1. Repeat this research in two to three years. This would permit a rich longitudinal study regarding how these variable change during this revolutionary transition. 
2. Repeat the study in other former Iron Curtain and other countries. There are many questions regarding cultural and environment issues which could be explored.

3. Add Western-owned Polish firms to the study. There are a few firms in Poland now with two or three years experience with Western management. The supra-system (organizational) will certainly be different in these firms and understanding the impact on the research questions in this study would be very informative.

4. Do another American study and add PES. It is quite possible that PES has a strong modifying influence on the job attribute preferences and this has not yet been studied in the U.S.

5. Develop theories and models appropriate to job attribute preference. There still is a significant need to develop theoretical underpinnings to this important and informative research subject.

\section{IMPLICATIONS FOR MANAGEMENT PRACTICES}

The results of this research points to implications for management practices, particularly as they relate to motivation of Polish worker.

Polish managers appear to more clearly understand what their workers wants from the work experience than Americans. Consequently, they are less likely to advance and design motivation policies that are a mismatch with workers' job attribute preferences than American managers. Furthermore, Western businessmen 
operating in Poland may be at a disadvantage in the human resources management arena.

It may be inappropriate for educators to assume that they know better than Polish managers and try to teach or implement Western motivational policies and strategies.

There are some interesting consequences of this research for the Polish manager. The Polish manager should feel somewhat confident in his clear and accurate knowledge of Polish workers.

Furthermore, it may be dangerous for Polish managers to implement Western motivational policies assuming that they will "work because they come from the West," without adding their own judgment using their knowledge about workers' preferences. In general, Polish managers should be careful in using Western management advice and models without critical evaluation.

Polish managers underestimate some important intrinsic job attributes such as Results, Develop, and Interesting. This suggests a significant un-tapped source of Polish worker motivation. Western tendencies towards Total Quality Management and worker empowerment should be explored and adopted.

\section{CONCLUSIONS}

The fundamental purpose of this study was to better understand the job attribute preferences of Polish managers and workers, the potential gaps between Polish managers' perception of their workers' preferences, and the organizational effect on these preferences. The author attempted to look at these issues with a systems science 
approach. Some key theories were supported by the results of this research while others theories were found to be lacking.

Maslow's prepotentcy theory was strongly supported by the results of this study. Linstone's theory regarding the affect of the supra-system (or organization) on the policies and attitudes within organizations was also supported. Questions were raised regarding the contrast between the predicted results of the managers' gaps in perception from the U.S. research and the Polish results. Additional questions were raised regarding the stability of the job attributes and the concept of clusters of extrinsic and intrinsic groups of job attributes. 


\section{REFERENCES}

Alderfer, C. P. (1977). Group and intergroup relations. In Hackman, J. R., \& Suttle, J. L. (Eds.), Improving life at work. Santa Monica, CA: Goodyear.

Beer, M., Spector, B., Lawrence, P. R. , Mills, D. Q.. \& Walton, R. E. (1985). Human Resource Management. New York: Free Press.

Blake, R. R. Shepard, H. A., \& Mouton, J. S. (1964). Managing Intergroup Conflict in Industry. Ann Arbor: Foundation for research on Human Behavior.

Blinder, A. S. (1991). How Japan Puts the "Human" in Human Capital, Business Week, November 11, 1991.

Budde, A., Child, J., Francis, A., Kieser, A., and Burgleman, R. Corporate Goals, Managerial Objectives, and Organizational Structures in British and West German companies. Organizational Studies, Vol 3, pp. 1-32.

Dunnette, M. D. \& Kirchner, W. K. (1965). Psychology applied to industry, New York: Appleton-Century-Crofts.

Dyer, L., \& Parker, D. F.(1975). Classifying Outcomes in Work Motivation Research: An Examination of the Intrinsic-Extrinsic Dichotomy. Journal of Applied Psychology, Vol. 60, pp. 455-458.

Economist (1991). A Survey of Business in Eastern Europe. The Economist, September 21, 1991, pp. 2-30.

Edelman, M., (1967). The Symbolic Uses of Politics, University of Illinois Press, Urbana.

Eder, R. W. (1988). Perceptions of worker job attribute preference in high technology firms. Proceedings: Managing the High Technology Firm Conference, Boulder, CO, pp. 16-22.

Eder, R. W., \& Tucker, N. R. (1988). Sensitizing management students to their misperceptions of line worker job attribute preferences. Organizational Behavior Teaching Review, Vol. 12, pp. 93-101. 
Falus, K. S. (1979). Expertise and Loyalty - the Top-level Managers of the Economy, pp. 81-95.

Feiwel, G. R. (1965). The Economics of a Socialist Enterprise - A Case Study of the Polish Firm, Frederick A. Praeger: New York.

Hackman, J. R. \& Oldham, G. R. (1976). Motivation Through the Design of Work: Test of a Theory, Organizational Behavior and Human Performance Vol. 16, p. 256.

Harari, O. and Beaty, D. (1989). Lessons from South Africa, New York: Harper \& Row.

Herzberg, F. (1966). Work and the Nature of Man, New York: World Publishing.

Hess, G. W. (1991). Eastern European Dealing: Let the Barter Beware. Iron Age, March 1991, pp. 18-23.

Hofstede, G. (1980). Culture's Consequences: International Differences in Work Related Values, Beverly Hills: Sage.

Hunt, D. M. (1992). Worker Attitudes in South Africa, in SW Review of International Business Research Proceedings of the 1992 Academy of International Business SW Regional Meeting, March 4-7 in San Antonio (Edited by S. K. Cooper) Texas A \& M University.

Hunt, D. M. (1992). South African Worker Attitudes: Why U.S. Motivation Theories Do Not Work Abroad, submitted to S.A.M. Advanced Management Journal, June 1992.

Jenner, R. A. and Gappa, J. (1979). Learning Under Fire: The Adaptabllity of Polish Managers to Competitive Market Conditions, Journal of World Trade, Vol 2, pp. 81-93.

Jurgensen, C. E. (1978). Job Preferences (What makes a Job Good or Bad?), Journal of Applied Psychology, .Vol. 63, No. 3, pp. 267276.

Kahn, R. L. (1972). The Meaning of Work: Interpretation and Proposals for Measurement. In Campbell, A. A. and Converse, P. E. (Eds.) The Human Meaning of Social Change, Basic Books.

Kolaja, J. (1960). A Polish Factory - A Case Study of Workers' Participation in Decision Making, University of Kentucky Press. 
Kotler, P. (1992). Marketing Management, Seventh Edition, New Jersey: Prentice Hall.

Kovach, K. A. (1987). What Motivates Employees? Workers and Supervisors Give Different Answers, Business Horizons, September, October, pp. 58-65.

Kovach, K. A. (1980). Why motivation theories don't work, (SAM) Advanced Management Journal, Spring pp. 54-59.

Kozminski, A. K. (1971). The Role of the Manager in Socialist Economy, Intentional Studies of Management and Organization. Spring, Vol. I, No. 1, pp. 65-87.

Lacy, W. B., Bokemeier, J. L., \& Shepard, J. M. (1983). Job attribute preferences and work commitment of men and women in the United States. Personnel Psychology, Vol. 36, pp. 315-329.

Lawrence, P. R., \& Vlachoutsicos, C. A. (1990). Managerial patterns: differences and commonalties. In P. R. Lawrence \& C. A. Vlachoutsicos (Eds.), Behind the factory walls: Decision making in Soviet and US enterprises , pp. 271-286. Boston: Harvard Business School Press.

Lendaris, G. G., (1986). On Systemness and the Problem Solver: Tutorial Comments, IEEE Transactions on Systems, Man, and Cybernetics, Vol. SMC-16, No. 4, July/August, pp. 604-610.

Levine, R. A. \& Campbell, D. T. (1972). Ethnocentrism. New York: Willey.

Linstone, H. A., (1984). Multiple Perspectives for Decision Making, New York: Elsevier Science Publishing Co., Inc.

Locke, E. A. (1982). Employee Motivation: A Discussion, Journal of Contemporary Business, Vol. 11, p.75.

Luthans, F. (1988). Successful vs. Effective Real Managers, The Academy of Management Executive, 1988, Vol. 11, No. 2, pp. 127-132.

Madhavan, R. and Fogel, D. S. (1992). In Support of Reforms: Western Business Education in Central and Eastern Europe, Review of Business, Vol. 13, \# 4, Spring, pp. 4-9.

Maslow, A. H. (1970). Motivation and Personality, New York: Harper \& Row. 
McClelland, D. (1962). Business Drive and National Achievement, Harvard Business Review, Vol 40, July/August, pp. 99-112.

McGregor, D. (1960). The Human Side of Management, New York: McGraw-Hill, pp. 33-34, 47-48.

Mintzberg, H. (1973). The Nature of Managerial Work, New York: Harper \& Row.

Moorman, R. H., and Podsakoff, P.M. (1992). A meta-analytic review and empirical test of the potential confounding effects of social desirability response sets in organizational behavior research, Journal of Occupational and Organizational Psychology, Vol. 65.

Naumienko, E. \& Dlugosz, M. (1989). Using management games to test Polish managers' preparation for economic reform. Paper presented at Twentieth ISAGA Conference, Weimar, Germany.

Peter, J. P., \& Olson, J. C. (1990). Consumer Behavior and Marketing Strategy, Second Edition. MA: Irwin.

Peters, T. J., \& Waterman Jr., R. H. (1982). In Search of Excellence: Lessons for America's Best-Run Companies, New York: Harper and Row, 1982.

Pfaff, M. (1977). Who Decides What is Good for Whom? Journal of Consumer Policy, Vol 1, 138-142.

Porter, L. W., \& Miles, R. E. (1974). Motivation and Management. In J. W. McGuire (Ed.), Contemporary management: Issues and viewpoints. Englewood Cliffs, N.J.: Prentice-Hall.

Posner, B. Z. and Schmidt, W. H. (1984). Values and the American Manager: An Update, California Management Review, Vol. XXVI, No. 3, Spring, pp. 202-216.

Rafelski, Z. (1992). Polish Privatization, McNeil Lehrer Reports, broadcasted on Public Broadcasting System (TV), June 2, 1992.

Ronen, S. (1986). Comparative and Multinational Management, New York: John Wiley \& Sons.

Schares, G. E., Olsen, K., Reaves, L., and Weiner, E. (1991). Reawakening -- A Market Economy Takes Root in Eastern Europe, Business Week, Special Report, April 15, 1991.

Schein, E. H. (1980). Organizational Psychology, third edition. Englewood Cliffs, NJ: Prentice-Hall. 
Schoderbek, P.P., Cosier, R. A., \& Aplin, J. C. (1991). Management. Second Edition, New York: Harcourt Brace Jovanovich.

Siegfried, W. D., McFarlane, I., \& Graham, D. B., et al. (1981). A Reexamination of Sex Differences in Job Preferences. Journal of Vocational Behavior, Vol. 18, pp. 30-42.

Slocum, J. W. Jr., \& Topichak, P. M (1972). Do cultural differences affect job satisfaction? Journal of Applied Psychology Vol. 56, pp. 177-178.

Smith, P. C., Kendall, L. M. and Hulin, C. L. (1969). The Measurement of Satisfaction in Work and Retirement, Chicago: Rand-McNally.

Spector, P. E., (1987). Method variance as an artifact in self-reported affect and perceptions at work: Myth or significant problem. Journal of Applied Psychology, 72, pp. 438-443.

Steers, R. W., and Porter, L. W. (1991). Motivation and Work Behavior. Fifth Edition, New York: McGraw-Hill.

Wolfe, J., (1991). On the Transfer of Market-Oriented Business Games to Eastern Bloc Cultures, pp. 202-214.

Yankelovich, D. L., \& Immerwahr, J. (1983). Putting the Work Ethic to Work. New York: The Public Agenda Foundation.

Zdravomyslov, A. and V. Iadov, V. (1964). An Attempt at a Concrete Study of Attitude Toward Work, Soviet Sociology, Vol. 3, pp. 315.

Zerbe, W. J., and Paulhus, D. L. (1987). Socially desirable responding in organizational behavior: A reconception. Academy of Management Review, 12, 250-264.

Zielinski, J. G.(1973). Economic Reforms in Polish Industry, Oxford University Press: New York. 
APPENDIX A

STATE DIRECTIVE TOPICS 


\section{APPENDIX A}

STATE DIRECTIVE TOPICS

- Value of marketable output in transfer prices

- Production quantity of the most important assortments

- Quantity of export output

- Total wage fund

- White collar wage fund

- Number of industrial workers

- Number of manual workers

- Number of skilled workers, including engineers

- Size of administrative and office staff

- Profit or loss

- Development fund

- Contribution to the reserve fund

- Share of profit to be paid to the state (or subsidy received)

- Budget subsidies for centralized investments

- Budget subsidies for factory housing

- Import of equipment and foreign currency limitations

- Limits for capital repairs

- Apportionment of the amortized fund between the state and the firm

- Aggregate working capital 
APPENDIX B

SUMMARY OF RESULTS FROM STUDIES ON THE GAPS OF JOB ATTRIBUTE PREFERENCES 
APPENDIX B

\section{SUMMARY OF RESULTS FROM STUDIES ON THE GAPS OF JOB ATTRIBUTE PREFERENCES}

\begin{tabular}{|c|c|c|c|c|c|c|c|c|}
\hline \multirow[b]{2}{*}{ Job Attribute } & \multicolumn{2}{|c|}{ Study 1} & \multicolumn{2}{|c|}{ Study 2} & \multicolumn{2}{|c|}{ Study 3} & \multicolumn{2}{|c|}{ Study 4} \\
\hline & Empl & Supv & Empl & Supv & Empl & Supv & Empl & Supv \\
\hline $\begin{array}{c}\text { Appreciation of work } \\
\text { done }\end{array}$ & 1 & 8 & 2 & 8 & 9 & 7 & 4 & 8 \\
\hline $\begin{array}{l}\text { Feeling of being in on } \\
\text { things }\end{array}$ & 2 & 9 & 3 & 10 & 6 & 5 & $\mathbf{8}$ & 10 \\
\hline $\begin{array}{l}\text { Help with personal } \\
\text { problems }\end{array}$ & 3 & 10 & 10 & 6 & 7 & 10 & 6 & 6 \\
\hline Job security & 4 & 2 & 4 & 2 & 3 & 2 & 2 & 1 \\
\hline Good wages (pay) & 5 & 1 & 5 & 1 & 1 & 1 & 1 & 2 \\
\hline Interesting work & 6 & 5 & 1 & 5 & 2 & 6 & 7 & 7 \\
\hline $\begin{array}{l}\text { Promotion and growth } \\
\text { in the firm }\end{array}$ & 7 & 3 & 6 & 3 & 5 & 4 & 4 & 5 \\
\hline $\begin{array}{l}\text { Personal loyalty to } \\
\text { fellow employee }\end{array}$ & 8 & 6 & 8 & 7 & 8 & 8 & $\mathbf{3}$ & 9 \\
\hline $\begin{array}{l}\text { Good workdng } \\
\text { conditions }\end{array}$ & 9 & 4 & 7 & 4 & 4 & 3 & $\mathbf{E}$ & $\mathbf{3}$ \\
\hline Tactful discipline & 10 & 7 & 9 & 9 & 10 & 9 & 10 & 9 \\
\hline
\end{tabular}

Study 1 -- 1946 study by the U.S. Labor Relations Institute (Kovach 1980)

Study 2 -- 1980 study by Kovach (Kovach 1980)

Study 3 -- 1989 study in South Africa (Hararl and Beaty 1989)

Study 4 -- 1992 study in South Africa (Hunt 1992)

Bold and underlined are labeled as "gaps" by the authors 
APPENDIX C

ENGLISH VERSION OF WORKER'S QUESTIONNAIRE 


\section{WHAT DO WORKERS WANT FROM THEIR JOB EXPERIENCE}

You are invited to participate in a confidential study of what is important to Polish workers in their job experience. This study is being done by F. Michael Sisavic, Director of the Polish American Partnership for Enterprise Development (PAPED) and Executive Vice President of the Free Market Business Development Institute (FMBDI).

The purpose of this study is to better understand worker motivation. The results of this research will be analyzed and compared with similar results from U.S. workers. A summary report will be sent to your enterprise and will be available for you to read. A summary of the results may be published and may be used by Polish managers to design better motivation policies.

Your participation in this research is voluntary and you will remain completely anonymous. Your name will not be on the questionnaire. The same research will be done in four different Polish enterprises and the results will be published as a summary of all workers' and managers' answers and not for any one individual.

The study involves answering a brief two part questionnaire:

Parts 1 \& 2 You are asked to rank and rate a list of items that are frequently mentioned as important to workers.

Part 3 You are asked to answer a few background questions.

Your participation is completely voluntary. Place the completed questionnaire in the supplied envelop and seal it. Completing both parts of the questionnaire should take about 15 minutes.

Thank you very much for your support for this research.

F. Michael Sisavic

Director, Polish American Partnership for Enterprise Development (PAPED). Executive Vice President, The Free Market Business Development Institute (FMBDI).

Portland State University.

October 1992 


\section{PART 1 .- WHAT DO YOU WANT FROM A JOB EXPERIENCE?}

Think about what you want from a job experience .- any job, not just the job you have now. Listed below are ten (10) items that are frequently mentioned as important to workers. Please rank the following items in the order of importance to you, not what you believe others think. Please note that there are no right or wrong answers, only what is right for you. Follow the instructions below.

\section{Ranking Instructions}

1. Review the list of items labeled "A" through "J" presented below.

2. Choose the most important item and place the corresponding letter below the Rank Order "1." For example, put " $A$ " below "1." Cross that item off the list.

3. Now choose the least important item and place the corresponding letter below the Rank Order "10." For example, put "B" below "10." Cross that item off the list.

4. Go back and repeat the procedure (ranking the next most important, next least important) until all ten Rank Orders are filled.

5. Turn the page and answer the questions in Part 2.

\section{Items Important to You in a Job Experience}
A. Seeing the results of my work
B. Job security; unlikely to lose my job
C. Interesting work
D. Job in a growing field or industry
E. Good pay
F. Chance to develop my skills and abilities
G. Recognition for a job well done
H. Good pension and other benefits
I. To be with people and have friends at work

J. Considerable "say" in how my job is performed

\begin{tabular}{|l|l|l|l|l|l|l|l|l|l|l|l|}
\hline Rank Order & 1 & 2 & 3 & 4 & 5 & 6 & 7 & 8 & 9 & 10 \\
\hline Items (A-J) & & & & & & \\
\hline
\end{tabular}




\section{PART 2 -- HOW IMPORTANT ARE THE ITEMS? \\ Instructions}

We are now interested in how important the items in Part 1 are to you. Listed below are the same ten (10) items that are frequently mentioned as important to workers. Please indicate, by a check mark, how important you feel each of the items are to you, using the scale from "Not Important" (1) to "Extremely Important" (5).

\begin{tabular}{|c|c|c|c|c|c|}
\hline Items Important to Me & Not Important & $\begin{array}{l}\text { Somewhat } \\
\text { Important } \\
\text { (2) }\end{array}$ & $\begin{array}{c}\text { Fairly } \\
\text { Important } \\
(3)\end{array}$ & $\begin{array}{l}\text { Very } \\
\text { Important } \\
(4)\end{array}$ & $\begin{array}{c}\text { Extremely } \\
\text { Importunt } \\
\text { (5) }\end{array}$ \\
\hline \multicolumn{6}{|l|}{ Seeing the results of my work } \\
\hline \multicolumn{6}{|l|}{$\begin{array}{l}\text { Job security; unlikely to lose my } \\
\text { job }\end{array}$} \\
\hline \multicolumn{6}{|l|}{ Interesting work } \\
\hline \multicolumn{6}{|l|}{ Job in a growing field or industry } \\
\hline \multicolumn{6}{|l|}{ Good pay } \\
\hline \multicolumn{6}{|l|}{$\begin{array}{l}\text { Chance to develop my skills and } \\
\text { abilities }\end{array}$} \\
\hline \multicolumn{6}{|l|}{ Recognition for a job well done } \\
\hline \multicolumn{6}{|l|}{ Good pension and other benefits } \\
\hline \multicolumn{6}{|l|}{$\begin{array}{l}\text { To be with people and have friends } \\
\text { at work }\end{array}$} \\
\hline $\begin{array}{l}\text { Considerable "say" in how my job } \\
\text { is performed }\end{array}$ & & & & & \\
\hline
\end{tabular}

Are there any items which are important to you in a job but are not listed above? Please list:

1.

2.

3.

Turn the page and answer the questions in Part 3. 


\section{PART 3 -- BACKGROUND INFORMATION}

This part asks a series of questions about you and your enterprise. Remember, your answers will be confidential. Please answer each question by filling in the blank or checking the appropriate response.

1. Please check the category which best describes your job (check only one).

Top Manager: Director, Executive, or General Manager

Middle or First Level: Supervisor, Foreman, or Department Manager

W White collar worker: marketing, engineer, other

Blue collar worker: assembly, manufacturing, other

Other (Please specify:

2. Please indicate how long you have worked for your current enterprise:

Months or Years

3. Please indicate your gender and age:

Female

Male

Years old

4. For the following questions please mark the appropriate space. Compared to a year ago is your situation better, the same, or worse?

$$
\text { Much The Much }
$$

Better Better Same Worse Worse

My standard of living is

My job security is

My confidence in the future is

My current type of work is 
APPENDIX D

ENGLISH VERSION OF MANAGER'S QUESTIONNAIRE 


\section{WHAT DO WORKERS WANT FROM THEIR JOB EXPERIENCE?}

You are invited to participate in a confidential study of what is important to Polish workers in their job experience. This study is being done by F. Michael Sisavic, Director of the Polish American Partnership for Enterprise Development (PAPED) and Executive Vice President of the Free Market Business Development Institute (FMBDI).

The purpose of this study is to better understand worker motivation. The results of this research will be analyzed and compared with similar results from U.S. workers. A summary report will be sent to your enterprise and will be available for you to read. A summary of the results may be published and may be used by Polish managers to design better motivation policies.

Your participation in this research is voluntary and you will remain completely anonymous. Your name will not be on the questionnaire. The same research will be done in four different Polish enterprises and the results will be published as a summary of all workers' and managers' answers and not for any one individual.

The study involves answering a brief questionnaire on what you believe workers in your enterprise most want from their job experience. You are also asked to answer a few background questions. Please complete all parts without stopping.

Your participation is completely voluntary. Place the completed questionnaire in the supplied envelop and seal it. Completing both parts of the questionnaire should take about 15 minutes.

Thank you very much for your support for this research.

F. Michael Sisavic

Director, Polish American Partnership for Enterprise Development (PAPED). Executive Vice President, The Free Market Business Development Institute (FMBDI).

Portland State University.

October 1992 


\section{PART 1 - WHAT DO WORKERS IN YOUR ENTERPRISE WANT FROMTHEIR JOB EXPERIENCE?}

Please assume that the president of your company has appointed you to a special committee to determine what workers in your enterprise want from their work or job experience. To help you with this task you have been provided a list of ten (10) items that are frequently mentioned as important to workers. Please rank the items as you think they would be ranked by workers in your enterprise.

\section{Ranking Instructions}

1. Review the list of Items labeled "A" through "J" presented below.

2. Choose the most important item and place the corresponding letter below the Rank Order "1." For example, put "A" below "1." Cross that item off the list.

3. Now choose the least important item and place that letter below the Rank Order "10." For example, put "B" below "10." Cross that item off the list.

4. Go back and repeat the procedure (ranking the next most important, next least important) until all ten Rank Orders are filled.

5. Turn the page and answer the questions in Part 2.

\section{Items Most Important to Workers in your Enterprise}

A. Seeing the results of their work

B. Job security; unlikely to lose their job

C. Interesting work

D. Job in a growing field or industry

E. Good pay

F. Chance to develop their skills and abilities

G. Recognition for a job well done

H. Good pension and other benefits

I. To be with people and have friends at work

J. Considerable "say" in how their job is performed

\begin{tabular}{|c|c|c|c|c|c|c|c|c|c|c|}
\hline & Most & & & & & & & & & Least \\
\hline Rank Order & 1 & 2 & 3 & 4 & 5 & 6 & 7 & 8 & 9 & 10 \\
\hline Items $(A-J)$ & & & & & & & & & & \\
\hline
\end{tabular}




\section{PART 2 -- HOW IMPORTANT ARE THE ITEMS? Instructions}

We are now interested in how important you believe the items in Part 1 are to worker's in your enterprise. Listed below are the same ten (10) items that are frequently mentioned as important to workers. Please indicate, by a check mark, how important you feel each of the items are to workers in your enter-prise, using the scale from "Not Important" (1) to "Extremely Important" (5).

\begin{tabular}{|c|c|c|c|c|c|}
\hline Items Important to Me & Not Important & $\begin{array}{l}\text { Somewhat } \\
\text { Important } \\
\text { (2) }\end{array}$ & $\begin{array}{c}\text { Fairly } \\
\text { Importent } \\
\text { (3) }\end{array}$ & $\begin{array}{c}\text { Very } \\
\text { Important } \\
\text { (4) }\end{array}$ & $\begin{array}{c}\text { Extremely } \\
\text { Important } \\
(5)\end{array}$ \\
\hline Seeing the results of their work & & & & & \\
\hline Job security; unlikely to lose their job & & & & & \\
\hline Interesting work & & & & & \\
\hline Job in a growing field or industry & & & & & \\
\hline Good pay & & & & & \\
\hline $\begin{array}{l}\text { Chance to develop their skills and } \\
\text { abilities }\end{array}$ & & & & & \\
\hline Recognition for a job well done & & & & & \\
\hline Good pension and other benefits & & & & & \\
\hline $\begin{array}{l}\text { To be with people and have friends at } \\
\text { work }\end{array}$ & & & & & \\
\hline $\begin{array}{l}\text { Considerable "say" in how their job is } \\
\text { performed }\end{array}$ & & & & & \\
\hline
\end{tabular}

Are there any items which are important to workers in your enterprise in a job experience but are not listed above? Please list:

1.

2.

3.

Turn the page and answer the questions in Part 3. 
PART 3 - WHAT DO YOU WANT FROM YOUR JOB EXPERIENCE?

Now, think about what you want from a job experience -- any job, not just the job you have now. Listed below are the same ten $(10)$ items that are frequently mentioned as important to workers and managers. Please rank the following items in the order of importance to yeu, not what you believe others think.

\section{Ranking Instructions}

1. Review the list of items labeled "A" through "J" presented below.

2. Choose the most important item and place the corresponding letter below the Rank Order "1." For example, put "A" below "1." Cross that item off the list.

3. Now choose the least important item and place the corresponding letter below the Rank Order "10." For example, put "B" below "10." Cross that item off the list.

4. Go back and repeat the procedure (ranking the next most important, next least important) until all ten Rank Orders are filled.

5. Turn the page and answer the questions in Part 2.

\section{Items Important to You in a Job}

A. Seeing the results of my work

B. Job security; unlikely to lose my job

C. Interesting work

D. Job in a growing field or industry

E. Good pay

F. Chance to develop my skills and abilities

G. Recognition for a job well done

H. Good pension and other benefits

I. To be with people and have friends at work

J. Considerable "say" in how my job is performed

\begin{tabular}{|c|c|c|c|c|c|c|c|c|c|c|}
\hline & Most & & & & & & & & & Leas \\
\hline Rank Order & 1 & 2 & 3 & 4 & 5 & 6 & 7 & 8 & 9 & 10 \\
\hline Items $(A-J)$ & & & & & & & & & & \\
\hline
\end{tabular}




\section{PART 4 -- BACKGROUND INFORMATION}

This part asks a series of questions about you and your enterprise. Remember, your answers will be confidential. Please answer each question by filling in the blank or checking the appropriate response.

1. Please check the category which best describes your job (check only one).

_ Top Manager: Director, Executive, or General Manager

Middle or First Level: Supervisor, Foreman, or Department Manager

- White collar worker: marketing, engineer, other

_ Blue collar worker: assembly, manufacturing, other

Other (Please specify:

2. Please indicate how long you have worked for your current enterprise:

Months or — Years

3. Please indicate your gender and age:

Female $\quad$ Male _ _ Years old

4. For the following questions please mark the appropriate space. Compared to a year ago is your situation better, the same, or worse?

$$
\text { Much The Much }
$$

Better Better Same Worse Worse

My standard of living is

My job security is

My confidence in the future is

My current type of work is 
APPENDIX E

ORGANIZATIONAL VARIABLES QUESTIONNAIRE 


\section{APPENDIX E}

\section{ORGANIZATIONAL VARIABLES QUESTIONNAIRE}

(Collected using Focus Group Interviews)

Company Name:

Person Interviewed:

Date:

1. Type of ownership

State

Joint Stock Company (State, but going private)

Private (Previously State owned)

Private (Never owned by the State)

2. Profitability

\section{Revenue}

Past: was or wasn't (magnitude)

Present: is or isn't (magnitude)

Future: short term, long term, or never

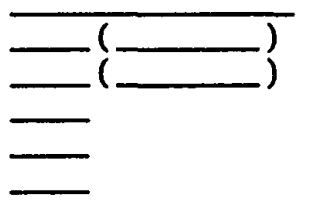

3. Stability of work force

Staff reductions or layoffs

Turmoil (strikes, etc.)

4. Work force Demographics

Number of employees

Percent of managers with advanced education

Percent of workers with advanced education

5. Industry

6. Products

7. Age of company

When formed

When reorganized or spun-off

When privatized

8. Western management training (None, some, lots)

9. Use of Western management (None, some, lots) 
APPENDIX F

MOTIVATIONAL PRACTICES AND SYSTEMS QUESTIONNAIRE 


\section{MOTIVATION PRACTICES AND SYSTEMS QUESTIONNAIRE \\ PART 1 -- VS. JOB ATTRIBUTE PREFERENCES \\ (Collected using Focus Group Interviews)}

Company Name:

Person Interviewed:

\section{Job Attribute Preference}

(Motivational Policies)
Date:

Doing Need to or
Now

A. Seeing the results of your work

Performance feedback systems

Personal goal setting encouraged

Worker sets priorities

Direct feedback system employee performance

B. Job security; unlikely to lose job

Full employment policy

Guarantees

Termination or layoff policies and process

Response to downtum/layoffs

Status of ideological subject?

C. Interesting work

Job Diagnostic Survey

Skill variety

Task identity

Task significance

Autonomy

Feedback

Whole job versus small part

Communication of value of job

Job rotations

Discretionary work time

D. Job in a growing field or industry

Industry growth

Company growth

Ability to transfer to other companies

Availability of other forms of work

\section{E. Good pay}

How is base salary determined New versus experienced workers Merit (individual, group, organization)

Rationale for merit pay 
Job Attribute Preference

(Motivational Policies)
Doing

Now
Need to or

want to do

F. Chance to develop your skills and abilities

Training programs

Responsibility for worker development

Job flexibility and cross training

G. Recognition for a job well done

Recognition systems

Banners

Individuals, group, company

Praise behavior

Worker surveys

H. Good pension and other benefits

List of benefits

Increasing or decreasing

Firm specific vs. Government sponsored

Percent of total compensation

I. To be with people and have friends at work

Company supported social activities

Company club and sports activities

Work group emphasis

Vacation facilities.

J. Considerable "say" in how job is performed

Availability of information on state of firm

Update on firm - newsletters, briefings

Suggestion box system

Control over sequence of work performed

Flexible work schedules

Policies/activities re: upward communication

Policies/activities re: downward communication

What decisions do workers make?

How are jobs designed? Worker role? 


\title{
MOTIVATION PRACTICES AND SYSTEMS QUESTIONNAIRE \\ PART 2 -- MOTIVATION POLICIES \\ (Collected using Focus Group Interviews)
}

Money How is base salary determined

$$
\begin{array}{lll}
\multicolumn{2}{c}{\text { New workers }} & \\
\text { Experienced workers } & \\
\text { Bonus plans } & \text { Individual } & \text { Based upon what? Why? } \\
& \text { Group wide } & \text { Based upon what? Why? } \\
& \text { Company wide } & \text { Based upon what? Why? }
\end{array}
$$$$
\text { Group wide Based upon what? Why? }
$$

Goal Setting

Participation

Job Enrichment - Flexible work schedules

Recognition Policies/Activities - Individuals, Group, Company

Survey of Workers

Never, occasionally, often

Subjects/goals

Communication (open, closed)

Policies/activities re: upward communication

Policies/activities re: downward communication

How do workers find about company/organization?

Company newsletter?

Gripe sessions

Decision making regarding workers' job content and methods, policies, strategies, company direction What decisions do workers make?

Any job rotation policy/activities?

How autonomous are workers?

Objectives/Goals? --Who sets them for the individual, group, company

Status of ideological subject?

Company sponsored clubs, sports, social activities, vacation facilities.

\author{
Benefits -- company and country sponsored \\ Pensions \\ Health insurance \\ Holidays and Vacation \\ Food (lunch, etc.) \\ Barter (clothing, etc.)
}




\section{APPENDIX G}

POLISH VERSION OF WORKERS AND

MANAGER'S QUESTIONNAIRE 


\section{CZEGO PRACOWNICY OCZEKUJA OD PRACY}

Zapraszamy Panią/Pana do uczestnictwa w anonimowych badaniach, mających na celu okreslenie co jest istotne dla polskich pracownikow w ich pracy. Badania te sa prowadzone przez Pana F. Michael Sisavic, Director of the Polish American Partnership for Enterprise Development (PAPED) oraz Executive Vice Presideat of the Free Market Business Development Institute (FMBDI).

Celem tych badań jest lepsze zrozumienie motywacji pracowników. Rezultaty tej ankiety beda przeanalizowane $\mathrm{i}$ porownane do podobnych badan przeprowadzonych wsrod amerykanskich pracowników. Podsumowane wyniki badan beda przeslane do Pañskiej furmy i bedą dostẹpne do Pañskiego wgladu. Istnieje możliwośc, że te wyniki beda opublikowane $i$ beda stanowic podstawe do formulowania lepszych programów motywacyjnych przez polskichmanadżerów.

Udzial w tych badaniach jest ochotniczy i anonimowy. Parskie nazwisko nie bedzie sie znajdowalo na ankiecie. Podobne badania beda preprowadzone w czterech polskich firmach i opublikowane rezultaty tego kwestionariusza beda podsumowaniem wszystkich nadeslanych odpowiedzi, a nie poszczegolnych osbb.

Badania te skYadają się z knotkiego kwestionariusza dotyczacego Pańskiego zdania na temat: czego glownie pracownicy w pańskiej firmie oczekuja od pracy. Dodatkowo zawarte sa ogolne pytania dotyczace fim, bioracych udzial w badaniach. Prosimy o wypelnienie wszystkich czessci bez zatrzymywania się.

Panski udzial jest calkowicie dobrowolny. Wypelniona ankiete prosimy włożyc do załaczonej koperty i wyslac ja na podany adres. Wypelnienie obu częsci kwestionariusza powinno zajac okolo 15 minut.

Dziekujemy serdecznie za udzial w tych badaniach.

\section{F. Michael Sisavic}

Director, Polish American Partnership for Enterprise Development (PAPED).

Executive Vice President, The Free Market Business Development Institute (FMBDI) Portland State University

Pazdziemik, 1992 


\section{CZESC 1 - CZEGO PANIPAN OCZEKUJE OD PRACY?}

Prosimy zastanowic się nad swoimi doświadczeniami w pracy - jakiejkolwiek pracy, niekoniecznie obecnej. Poniżej wyszczególnionych jest dziesiẹd (10) czynnikow szczegolnie ważnych dla pracowników. Prosimy o uszeregowanie tych czynnikow wediug Pańskiej ważności, a nie opini ogớlu. Pragniemy zaznaczyc, że tu nie ma dobrej lub złej odpowiedzi, jest jedynie Pańska opinia. Prosimy przesledzic podane ponizej instrukcje.

\section{Instrucja Oceniania}

1. Przeczytaj wszystkie z przedstawionych poniżej czynnikow od "A" do "J".

2. Wybiez najbardziej ważny czynnik i wpisz odpowiednią litere pod Stopniem Ważnosci 1. Naprzykład: Postaw "A" poniziej "1". Skresil ten czynnik z listy.

3. Wybież naimniei istomy czynnik i wpisz odpowiednia litere pod Stopniem Ważnosci 10. Naprzykład: Postaw "B" ponizej "10". Skresl ten czynnik z listy.

4. Nasteppnie powtorz krok 2 i 3 (oceń najbardziej ważny i najmniej istotny czynnik pracy) dopóki Stopien Ważnosci nie zostanie całkowicie wypetniony.

5. Odpowiedz na pytania w Czessci 2.

\section{NAJWAŻNIEJSZE DLA PANIPANA CZYNNIKI PRACY}

A. Widzieć rezultaty mojej pracy.

B. Gwarancja mojego miejsca pracy.

C. Interesujaca praca.

D. Praca w rozwijającej sie galęzi lub przemyśle.

E. Dobra placa.

F. Szansa rozwijania moich umiejętnosci i zdolnosici.

G. Docenianie dobrze wykonanej pracy.

H. Dobra emerytura i inne korzysci socjalne

I. Być z ludżmi i mieć przyjaciol w pracy.

J. Możliwosć wlasnego zdania jak wykonac moją pracę.

\begin{tabular}{|l|c|c|c|c|c|c|c|c|c|c|}
\hline $\begin{array}{l}\text { Stopien } \\
\text { Ważnosci }\end{array}$ & 1 & 2 & 3 & 4 & 5 & 6 & 7 & 8 & 9 & 10 \\
\hline $\begin{array}{l}\text { Czynniki } \\
\text { Pracy (A-Л) }\end{array}$ & & & & & & & & & & \\
\hline
\end{tabular}




\section{CZESŚC 2 - JAK WAŻNE SA TE CZYNNTKT?}

\section{Instrukcje}

Czescc ta ma na celu uzyskanie informacji jak ważne sa te czynniki zawarte w Czesci 1 dla Pani/Pana. Poniżej podanych jest dziesię (10) czynników szczegolnie ważnych dla pracownikow. Prosimy wskazac krzyżykiem (x) stopień ważnosci tych czynników dla Pani/Pana, używając skali: od "Nieważny" (1) do "Niezwykle ważny" (5).

\begin{tabular}{|c|c|c|c|c|c|}
\hline Czynniki & $\begin{array}{c}\text { Niewainy } \\
\text { (1) }\end{array}$ & $\begin{array}{l}\text { Trocbe } \\
\text { Wainy } \\
\text { (2) }\end{array}$ & $\begin{array}{l}\text { Wainy } \\
\text { (3) }\end{array}$ & $\begin{array}{c}\text { Bardzo } \\
\text { Wainy } \\
\text { (4) }\end{array}$ & $\begin{array}{c}\text { Niezwylkle } \\
\text { Waziny } \\
\text { (5) }\end{array}$ \\
\hline Widziec rezuitary mojej pracy. & & & & & \\
\hline Gwarancja mojego miejsca pracy. & & & & & \\
\hline Interesuiaca praca. & & & & & \\
\hline Praca w rozwilajacei sie galezi lub przemvśle. & & & & & \\
\hline Dobra placa. & & & & & \\
\hline Szansa rozwijania moich umiejetności i zdolnoś & & & & & \\
\hline Docenianie dobrze wykonanei pracy. & & & & & \\
\hline Dobra emerytura $i$ inne korzvsci socialne & & & & & \\
\hline Bvć z ludźmi i miec przyjaciór w pracy. & & & & & \\
\hline Mozliwosec wlasnego zdania jak wukonac prace. & & & & & \\
\hline
\end{tabular}

Czy sa inne ważne czynniki pracy dla Pani/Pana, ktore nie byly wyszczegoinione powyżej. Prosimy je wymienić:

1 .

2.

3. 


\section{CZESĊ 3 - CZEGO PANIPAN OCZEKUJE OD PRACY?}

Tym razem, prosimy zastanowic sie nad swoimi doswiadczeniami w pracy - jakiejkolwiek pracy, niekoniecznie obecnej. Poniżej wyszczegolnionych jest tych samych dziesięc (10) czynnikow szczegolnie ważnych dla pracownikow. Prosimy o uszeregowanie tych czynnikow wedlug Panskiej ważnosci, a nie opini ogolu.

\section{Instrucja Oceniania}

1. Przeczytaj wszystkie z przedstawionych poniżej czynników od "A" do "J".

2. Wybież naibardziei ważny czynnik i wpisz odpowiednią litere pod Stopniem Ważnosci 1. NaprzykJad: Postaw "A" poniżej "1". Skresl ten czynnik z listy.

3. Wybiez naimniei istotny czynnik i wpisz odpowiednia litere pod Stopniem Ważnosci 10. NaprzykJad: Postaw "B" poniżej "10". Skresil ten czynnik z listy.

4. Nastepnie powtorz krok 2 i 3 (oceń najbardziej ważny i najmniej istotny czynnik pracy) dopöki Stopien Ważnosci nie zestanie całkowicie wypelniony.

5. Odpowiedz na pytania w Cześci 3.

\section{NAJWAŻNIEJSZE dLA PANIPANA CZYNNIKI PRACY}

A. Widziec rezultaty mojej pracy.

B. Gwarancja mojego miejsca pracy.

C. Interesująca praca.

D. Praca w rozwijającej sie galẹzi lub przemysile.

E. Dobra placa.

F. Szansa rozwijania moich umiejetnosci i zdolnosci.

G. Docenianie dobrze wykonanej pracy.

H. Dobra emerytura i inne korzysci socjalne

1. Byc z ludżmi i miec przyjaciol w pracy.

J. Możliwosc wlasnego zdania jak wykonac moja prace.

\begin{tabular}{|l|l|l|l|l|l|l|l|l|l|l|}
\hline $\begin{array}{l}\text { Stopien } \\
\text { Wainosci }\end{array}$ & 1 & 2 & 3 & 4 & 5 & 6 & 7 & 8 & 9 & 10 \\
\hline $\begin{array}{l}\text { Czynniki } \\
\text { Pracy (A-ת) }\end{array}$ & & & & & & & & & & \\
\hline
\end{tabular}




\section{CZESSC 4 - DODATKOWE INFORMACJE}

Czesć 4 zawiera szereg pytan dotyczacych Pani/Pana i Pańskiej firmy. Prosimy pamietac, że Pańskie odpowiedzi beda poufne. Prosimy zakreslic odpowiednią odpowiedż lub wypetnic dane.

1. Prosimy zaznaczyc jedna kategorie, ktora najlepiej okresla Panskie stanowisko

_ Dyrektor, Prezes, Kierownik, Zaradzający, Brygadzista, Kierownik Wydziału, Pracownik umysiowy: biuro, marketing, inżynier, inne, Pracownik fizyczny: montowanie, wytwarzanie, inne, Inne (Prosimy okreslic:

2. Prosimy o podanie czasu pracy w obecnym przedsiębiorstwie: miesięcy lub lat.

3. Prosimy o okreslenie plci i wieku: kobieta meizzyzma lat.

4. Prosimy zakreslic wlasciwa odpowiedz. Porownujac do poprzedniego roku, Panska sytuacja jest lepsza, taka sama, lub gorsza?

$\begin{array}{llll}\text { Znacznie } & \text { Taka } & \text { Znacznie } \\ \text { lepsza } & \text { Lepsza } & \begin{array}{l}\text { sama } \\ \text { gorsza }\end{array} \text { Gorsza }\end{array}$

Moj poziom życia jest

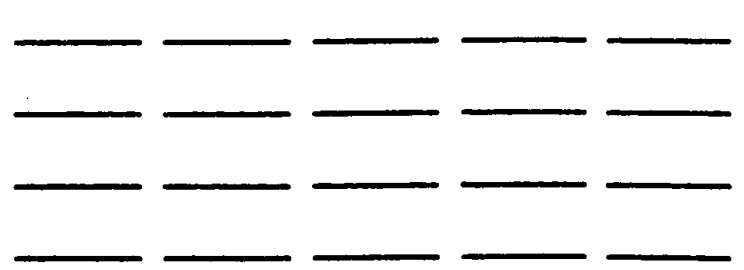

Moja gwaracja pracy jest

Moje zaufanie w przyszlośc jest

Moja obecna praca jest

Prosimy włożyć kwestionariusz do zalaczonej koperty i wyslac go na adres:

F. Michael Sisavic

Free Market Business Development Institute

Portland State University

Box 751 Portland OR 97201

U.S.A. 


\section{CZEGO PRACOWNICY OCZEKUJA, OD PRACY}

Zapraszamy Pania/Pana do uczestnictwa w anonimowych badaniach, majacych na celu okreslenie co jest istotne dla polskich pracownikow w ich pracy. Badania te sa prowadzone przez Pana F. Michael Sisavic, Director of the Polish American Partnership for Enterprise Development (PAPED) oraz Executive Vice President of the Free Market Business Development Institute (FMBDI).

Celem tych badan jest lepsze zrozumienie motywacji pracownikow. Rezultaty tej ankiety beda przeanalizowane $\mathrm{i}$ porownane do podobnych badan preprowadzonych wsrod amerykanskich pracownikow. Podsumowane wyniki badan beda przeslane do Panskiej firmy i beda dostepne do Panskiego wgladu. Istnieje możliwosc, że te wyniki beda opublikowane i beda stanowic podstawe do formulowania lepszych programow motywacyjnych przez polskichmanadżerow.

Udzial $w$ tych badaniach jest ochotniczy $i$ anonimowy. Panskie nazwisko nie bedzie sie znajdowalo na ankiecie. Podobne badania beda przeprowadzone w czterech polskich firmach i opublikowane rezultaty tego kwestionariusza beda podsumowaniem wszystkich nadeslanych odpowiedzi, a nie poszczegolnych osob.

Badania te skladają się $\mathbf{z}$ krotkiego, trzy czesciowego kwestionariusza:

Czesc 1 i 2 Dotyczy uszeregowania wedlug ważnosci listy czynnikow, ktore najczesciej wskazywane sa przez pracownikow jako istotne czynniki pracy.

Czesc 3 Zawiera ogolne pytania dotyczace uczestmikow i firm, bioracych udzial w badaniach.

Panski udzial jest calkowicie dobrowolny. Wypelniona ankiete prosimy wlożyc do zalaczonej koperty i wyslac ja na podany adres. Wypeinienie calego kwestionariusza powinno zajac okolo 15 minut.

Dziẹkujemy serdecznie za udzial w tych badaniach.

F. Michael Sisavic

Director, Polish American Partnership for Enterprise Development (PAPED).

Executive Vice President, The Free Market Business Development Institute (FMBDI)

Portland State University

Pazdziemik, 1992 


\section{CZESC 1 - CZEGO PRACOWNICY W PANSKIEJ FIRMIE OCZEKUJA OD PRACY?}

Prosimy sobie wyobrazic, ze Dyrektor Panskiej firmy wybrad Pania/Pana do specjalnej komisji, majacej na celu okreslenia czego pracownicy w Panskiej firmie oczekuja od pracy i doswiadczen zawodowych. Aby ułatwic to zadanie, przeslano Pani/Panu liste dziesieciu (10) czynniköw szczegolnie ważnych dla pracowników w Pańskiej firmie. Prosimy o uszeregowanie tych czynników według ważności dla pracownikow Panskiej firmy.

\section{Instrucja Oceniania}

1. Przeczytaj wszystkie z przedstawionych poniżej czynników od " $\mathrm{A}$ " do "J".

2. Wybież naibardziej ważny czynnik i wpisz odpowiednią litere pod Stopniem Ważnosci 1. Naprzykład: Postaw "A" poniżej "1". Skresl ten czynnik z listy.

3. Wybież najmniej istotny czynnik i wpisz odpowiednia litere pod Stopniem Ważosci 10. Naprzykład: Postaw "B" poniżej "10". Skresl ten czynnik z listy.

4. Nastepnie powtorz krok 2 i 3 (oceń najbardziej ważny i najmniej istotny czynnik pracy) dopoki Stopien Ważnosci nie zostanie całkowicie wype'niony.

5. Odpowiedz nà pytania w Czẹści 2.

\section{NAJWAŻNIEJSZE CZYNNIKI PRACY DLA PRACOWNIKóW}

A. Widzieć rezultaty ich pracy.

B. Gwarancja ich miejsca pracy.

C. Interesujagca praca.

D. Praca w rozwijającej się galęzi lub przemyśle.

E. Dobra placa.

F. Szansa rozwijania ich umiejętności i zdolnosici.

G. Docenianie dobrze wykonanej pracy.

H. Dobra emerytura i inne korzyści socjalne

I. Być z ludźmi i miec przyjaciol w pracy.

J. Możliwosć wlasnego zdania jak wykonać ich pracẹ.

\begin{tabular}{|l|c|c|c|c|c|c|c|c|c|c|}
\hline \begin{tabular}{|l|l|l|l|l|l|} 
Stopieni \\
Wänosci
\end{tabular} & 1 & 2 & 3 & 4 & 5 & 6 & 7 & 8 & 9 & 10 \\
\hline $\begin{array}{l}\text { Czynniki } \\
\text { Praci:(A-J) }\end{array}$ & & & & & & & & & & \\
\hline
\end{tabular}




\section{CZEŚC 2 - JAK WAŻNE SA TE CZYNNIKI?}

\section{Instrukcje}

Częsć ta ma na celu uzyskanie informacji jak Pańskim zdaniem ważne sa te czynniki zawarte w Czesci 1 dla pracownikow Panskiej firmy. Ponizej podanych jest dziesięc (10) czynników szczegolnie ważnych dla pracownikow. Prosimy wskazac krzyżykiem (x) stopien ważnosci tych czynnikow dla Pani/Pana, używając skali: od "Nieważny" (1) do "Niezwykle ważn" (5).

\begin{tabular}{|c|c|c|c|c|c|}
\hline Czynniki & $\begin{array}{c}\text { Niewainy } \\
\text { (1) }\end{array}$ & $\begin{array}{l}\text { Troche } \\
\text { Wainy } \\
\text { (2) }\end{array}$ & $\begin{array}{l}\text { Wainy } \\
\text { (3) }\end{array}$ & $\begin{array}{l}\text { Bantzo } \\
\text { Wainy } \\
\text { (4) }\end{array}$ & $\begin{array}{l}\text { Niezwykde } \\
\text { Waziny } \\
\text { (S) }\end{array}$ \\
\hline Widziec rezuläâly ich pracy. & & & & & \\
\hline Gwarancia ich mieisca pracy. & & & & & \\
\hline Interesuiaca praca & & & & & \\
\hline Praca w rozwiiajacei sie garezi lub przemvśle. & & & & & \\
\hline Dobra placa & & & & & \\
\hline Szansa rozwijania ich umicietnosci i zdolnosci. & & & & & \\
\hline Docenianie dobrze wukonanei pracy. & & & & & \\
\hline Dobra emervtura i inne korzysci socialne & & & & & \\
\hline Buc $z$ ludzmi i miec przviaciol $w$ pracy. & & & & & \\
\hline Moz̀liwośc wlasnego zdania jak wvkonac ich prace. & & & & & \\
\hline
\end{tabular}

Czy sa inne ważne czynniki pracy dla pracownikow Pańskiej firmy, ktore nie byly wyszczegolnione powyżej. Prosimy je wymienic:

1.

2.

3. 


\section{CZESŚ́ 3 - DODATKOWE INFORMACJE}

Czésc 3 zawiera szereg pytan dotyczacych Pani/Pana i Pańskiej firmy. Prosimy pamietac, że Pańskie odpowiedzi beda poufne. Prosimy zakreslić odpowiedniz̨ odpowiedż lub wypelnic dane.

1. Prosimy zaznaczyć jedną kategorię, która najlepiej okresla Pańskie stanowisko

_ Dyrektor, Prezes, Kierownik, Zarzadzajacy, Brygadzista, Kierownik Wydzialu, Pracownik umyslowy: biuro, marketing, inżynier, inne, Pracownik fizyczny: montowanie, wytwarzanie, inne, Inne (Prosimy okreslic:

2. Prosimy o podanie czasu pracy w obecnym przedsiębiorstwie: miesięcy lub lat.

3. Prosimy o określenie plci i wieku: kobieta mężczyzma lat.

4. Prosimy zakreslic wlasciwa odpowiedź. Porównujac do poprzedniego roku, Pańska sytuacja jest lepsza, taka sama, lub gorsza?

\begin{tabular}{|c|c|c|c|}
\hline & Lepsza & $\begin{array}{l}\text { Taka } \\
\text { sama }\end{array}$ & Gorsza \\
\hline
\end{tabular}

Moj poziom życia jest

Moja gwaracja pracy jest
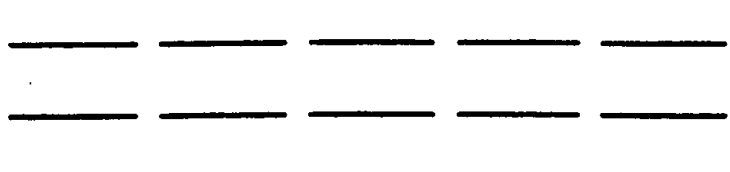

Moje zaufanie w przyszlośc jest

Moja obecna praca jest

Prosimy włożyć kwestionariusz do zalączonej koperty i wyslac go na adres:

F. Michael Sisavic

Free Market Business Development Institute

Portland State University

Box 751 Portland OR 97201 
APPENDIX H

FIRM DEMOGRAPHICS 


\section{APPENDIX $\mathrm{H}$}

\section{FIRM DEMOGRAPHICS}

\begin{tabular}{|c|c|c|c|c|c|}
\hline & IKSAIP & Cuprum & PZL & Tel Eko & Vigor \\
\hline Ownership & $\begin{array}{l}\text { State } \\
\text { (no plans for } \\
\text { privatization) }\end{array}$ & $\begin{array}{c}\text { State } \\
\text { (plans to } \\
\text { privatize } \\
\text { 1994) }\end{array}$ & $\begin{array}{l}\text { State } \\
\text { (plans to } \\
\text { privatize } \\
\text { 1992) }\end{array}$ & $\begin{array}{c}\text { Private } \\
\text { (recently } \\
\text { prlvatized } \\
\text { 1992) } \\
\end{array}$ & $\begin{array}{c}\text { Private } \\
\text { (never state } \\
\text { owned) }\end{array}$ \\
\hline Year founded & 1977 & 1967 & 1961 & 1964 & 1987 \\
\hline Industry & Computers & $\begin{array}{l}\text { Mining } \\
\text { Design }\end{array}$ & Fluid Power & Electronics & Software \\
\hline Products & $\begin{array}{l}\text { Industrial } \\
\text { controls }\end{array}$ & $\begin{array}{l}\text { Below } \\
\text { surface } \\
\text { mines }\end{array}$ & $\begin{array}{l}\text { Hydraulic } \\
\text { pumps }\end{array}$ & $\begin{array}{l}\text { Pollution } \\
\text { controls }\end{array}$ & $\begin{array}{l}\text { Accounting } \\
\text { software }\end{array}$ \\
\hline Staffing - 1980s & 700 & 1,050 & 1,200 & 400 & 120 \\
\hline-1990 & 600 & 500 & 650 & 400 & 90 \\
\hline - 1991 & 450 & 450 & 550 & 400 & 70 \\
\hline - today & 300 & 340 & 483 & 210 & 37 \\
\hline $\begin{array}{l}1991 \text { Revenue } \\
\text { (millions) }\end{array}$ & $\$ 2.67$ & $\$ 2.27$ & $\$ 10.0$ & $\$ 2.67$ & $\$ 0.50$ \\
\hline Profits - past & High & High & High & High & High \\
\hline - present & High & Medium & High & Medium & None \\
\hline - future & Higher & Higher & Higher & Higher & Better \\
\hline $\begin{array}{l}\text { Western mgmnt - } \\
\text { training }\end{array}$ & None & Very little & Very little & A little & Some \\
\hline $\begin{array}{l}\text { Western mgmnt - } \\
\text { application }\end{array}$ & None & Almost none & Almost none & A little & Some \\
\hline
\end{tabular}


APPENDIX I

FREQUENCY DISTRIBUTION OF THE PERSONAL ECONOMIC SITUATION (PES) 
APPENDIX I

FREQUENCY DISTRIBUTION OF THE PERSONAL ECONOMIC SITUATION (PES)

\begin{tabular}{|c|c|c|c|c|}
\hline PES Rating & Frequencies & Percent & $\begin{array}{c}\text { Cumulative } \\
\text { Percent }\end{array}$ & \\
\hline 1.33 & 1 & .3 & .3 & \multirow{5}{*}{$\begin{array}{l}\text { Tends to be } \\
\text { optimistic }\end{array}$} \\
\hline 1.67 & 2 & .6 & 1.0 & \\
\hline 2.00 & 6 & 1.9 & 2.9 & \\
\hline 2.33 & 12 & 3.8 & 6.7 & \\
\hline 2.67 & 24 & 7.6 & 14.3 & \\
\hline 3.00 & 34 & 10.7 & 25.2 & \multirow{2}{*}{ Neutral } \\
\hline 3.33 & 37 & 11.7 & 36.9 & \\
\hline 3.67 & 47 & 14.8 & 51.9 & \multirow{5}{*}{$\begin{array}{l}\text { Tends to be } \\
\text { pessimistic }\end{array}$} \\
\hline 4.00 & 50 & 15.8 & 67.8 & \\
\hline 4.33 & 47 & 14.8 & 82.8 & \\
\hline 4.67 & 34 & 10.7 & 93.6 & \\
\hline 5.00 & 20 & 6.3 & 100.0 & \\
\hline
\end{tabular}

Note: Lower PES values mean more optimistic (maximum optimism $=1.33$ ) and higher PES values mean more pessimistic (maximum pessimism = 5.00). The 3.00 rating is neutral (neither optimistic or pessimistic). 